Prepared in cooperation with Utah State University and Northern Arizona University

Streamflow and Sediment Data Collected to Determine the Effects of Low Summer Steady Flows and Habitat Maintenance Flows in $\mathbf{2 0 0 0}$ on the Colorado River between Lees Ferry and Bright Angel Creek, Arizona

By John C. Schmidt, David J. Topping, David M. Rubin, Joseph E. Hazel, Jr., Matt Kaplinski, Stephen M. Wiele, and Sara A. Goeking

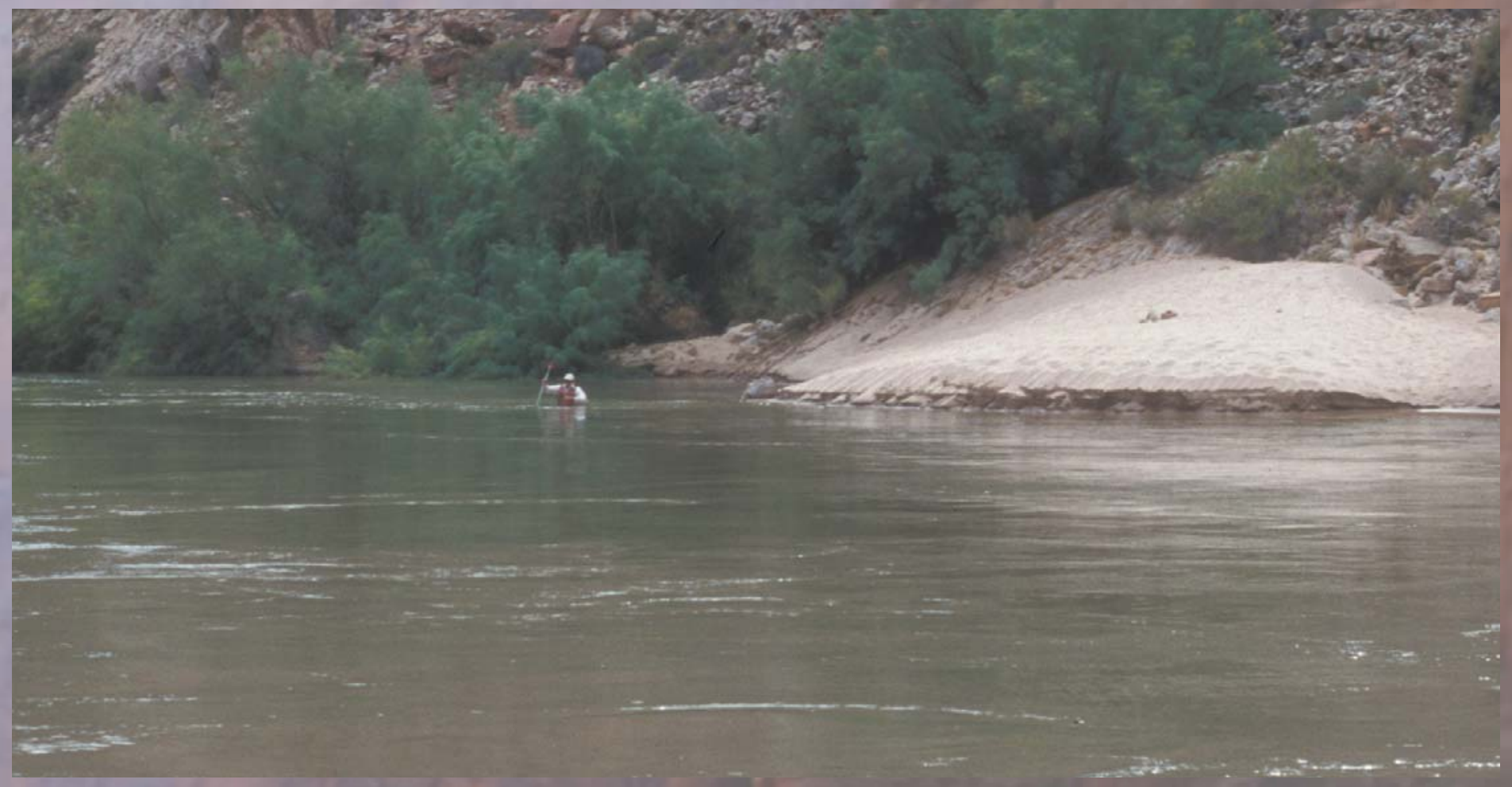

Open-File Report 2007-1268

U.S. Department of the Interior

U.S. Geological Survey 
Cover: Joe Hazel, Northern Arizona University, surveying the underwater part of the sandbar at river mile 30.7 on September 6, 2000 (photograph by David J. Topping, U.S. Geological Survey); (background) Marble Canyon, Ariz. (photograph by Jeff Sorensen, Arizona Game and Fish Department). 


\section{Streamflow and Sediment Data Collected to Determine the Effects of Low Summer Steady Flows and Habitat Maintenance Flows in $\mathbf{2 0 0 0}$ on the Colorado River between Lees Ferry and Bright Angel Creek, Arizona}

By John C. Schmidt, David J. Topping, David M. Rubin, Joseph E. Hazel, Jr., Matt Kaplinski, Stephen M. Wiele, and Sara A. Goeking

Open-File Report 2007-1268

U.S. Department of the Interior

U.S. Geological Survey 


\section{U.S. Department of the Interior DIRK KEMPTHORNE, Secretary}

\section{U.S. Geological Survey \\ Mark D. Myers, Director}

U.S. Geological Survey, Reston, Virginia 2007

Revised and reprinted: 2007

For product and ordering information:

World Wide Web: http://www.usgs.gov/pubprod

Telephone: 1-888-ASK-USGS

For more information on the USGS - the Federal source for science about the Earth, its natural and living resources, natural hazards, and the environment:

World Wide Web: http://www.usgs.gov

Telephone: 1-888-ASK-USGS

Suggested citation:

Schmidt, J.C., Topping, D.J., Rubin, D.M., Hazel, J.E., Jr., Kaplinski, M, Wiele, S.M., and Goeking, S.A., 2007, Streamflow and sediment data collected to determine the effects of low summer steady flows and habitat maintenance flows in 2000 on the Colorado River between Lees Ferry and Bright Angel Creek, Arizona: U.S. Geological Survey Open-File Report 2007-1268, 79 p.

Any use of trade, product, or firm names is for descriptive purposes only and does not imply endorsement by the U.S. Government.

Although this report is in the public domain, permission must be secured from the individual copyright owners to reproduce any copyrighted material contained within this report. 


\section{Contents}

Abstract

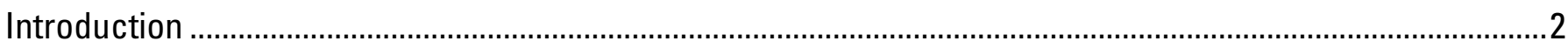

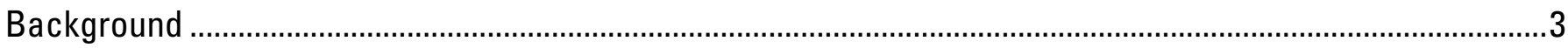

Dam Releases during the Study Period ...............................................................................................6

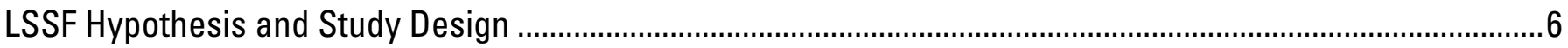

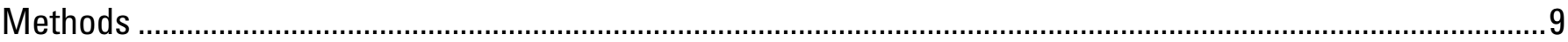

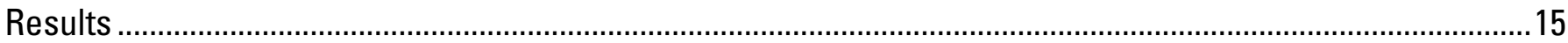

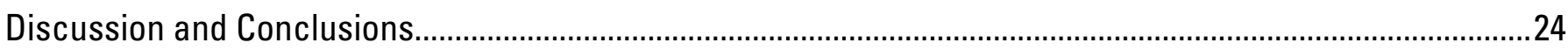

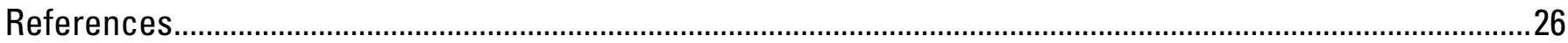

\section{Figures}

1. Map showing the Colorado River in Marble and Grand Canyons .................................................................

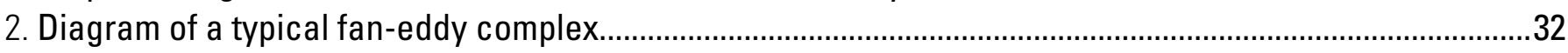

3. Diagram showing method of calculation of eddy deposition zones. ........................................................3

4. Hydrograph showing releases from Glen Canyon Dam (as measured at the Lees Ferry gaging station) throughout the six periods of the low summer steady flows (LSSF) experiment..................................34

5. Stage and temperature at river mile 30.7 during the September 2000 habitat maintenance flows...............35

6. Cumulative size distributions of eddies in previous studies and low summer steady flows reaches ...........36

7. Diagram showing a sample backwater opening in the upstream direction.................................................37

8. Hydrographs of the (A), Colorado River at the Lees Ferry, (B) Lower Marble Canyon, (C) Grand Canyon, and (D) Diamond Creek gaging stations from April 1-0ctober 1, 2000 ...............................................38

9. Hydrographs of three tributaries to the Colorado River: (A) the Paria River, (B) the Little Colorado River, and (C) House Rock Wash.

10. Measurements of (A) suspended-sand and (B) silt and clay concentrations at the Paria River at Lees Ferry gaging station during the study period...

11. Measurements of suspended-sediment concentration in House Rock Wash during the study period....41

12. Measurements of (A) suspended-sand and (B) silt and clay concentrations at the Little Colorado River near Cameron, Ariz., gaging station during the study period.

13. Measurements of $(A)$ suspended-sand and (B) silt and clay concentrations in the Colorado River at the Lower Marble Canyon and Grand Canyon gaging stations during the study period.

14. Measurements of (A) suspended-silt and clay concentration, (B) suspended-sand concentration, and (C) median grain size of suspended sand during the May and September habitat maintenance flows (HMF).

15. Measured surface (A) suspended-sand and (B) silt and clay concentrations (with smoothed curves) during May, July, and September 2000

16. Depth-integrated measurements of suspended sediment (with smoothed curves) from the Lagrangian sampling trip during the September habitat maintenance flows (HMF)..............................................46

17. Computed cumulative sand transport during the study period................................................................4

18. Model-predicted versus measured instantaneous (A) sand and (B) silt and clay loads in the Paria River

at Lees Ferry during the study period. ...........................................................................................4

19. Suspended-sand rating curve used to estimate the concentration of suspended sand in the Little Colorado River. 
20. Mass-balance sand budget uncertainty envelopes for Marble Canyon and upper Grand Canyon during Periods $1-5$

21. Mass-balance silt and clay budget uncertainty envelopes for Marble Canyon during Periods 1-5.........51

22. Fraction of bed area (in \%) composed of each bed-texture class before and after the September habitat maintenance flows (HMF) in the three study reaches in Marble Canyon, as determined from side-

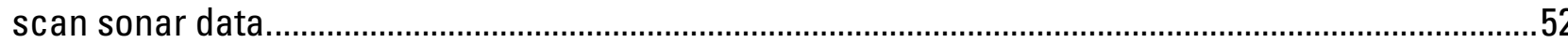

23. Comparison of the sand budget and $\beta$ at the Grand Canyon gaging station during Period 1 53

24. Graphs showing temporal changes in the area and volume of fine sediment between the stages associated with discharges of $227 \mathrm{~m}^{3} / \mathrm{s}$ and $708 \mathrm{~m}^{3} / \mathrm{s}$ at 17 study sites in Marble and upper Grand Canyons.

25. Graphs showing temporal changes in the area and volume of fine sediment above the stage associated with the discharge of $708 \mathrm{~m}^{3} / \mathrm{s}$ at 17 study sites in Marble and upper Grand Canyons

26. Graphs showing the temporal sequence of the mean $(A)$ and median $(B)$ area of mid-elevation finesediment deposits in larger eddies (i.e., in only the eddies larger than 1,000 $\mathrm{m}^{2}$ ) between 1984 and 2001

27. Graphs showing the temporal sequence of mid-elevation fine-sediment deposits, or the area of fine sediment inundated between the stages associated with discharges of 227 and $708 \mathrm{~m}^{3} / \mathrm{s}$, between 1984 and 2000

28. Graph showing the cumulative fill ratio for mid-elevation fine-sediment deposits for four reaches and Marble Canyon, mapped at a common discharge of $227 \mathrm{~m}^{3} / \mathrm{s}$.

29. Box-and-whisker plots showing the distribution of areas of mid-elevation fine-sediment deposits in larger eddies (i.e., in only the eddies larger than $1,000 \mathrm{~m}^{2}$ ) in four reaches and Marble Canyon, mapped at a common discharge of $227 \mathrm{~m}^{3} / \mathrm{s}$.

30. Box-and-whisker plots of the distribution of fill ratios for mid-elevation fine-sediment deposits in larger eddies (i.e., in only the eddies larger than $1,000 \mathrm{~m}^{3}$ ), mapped at a common discharge of $227 \mathrm{~m}^{3} / \mathrm{s} . . .60$

31. Histograms showing the number of eddies in which the area of low-elevation fine-sediment deposits increased or decreased by more than $200 \mathrm{~m}^{2}$ in each time interval, mapped at a common discharge of $227 \mathrm{~m}^{3} / \mathrm{s}$

32. Graphs showing the distribution of net normalized aggradation (NNA) in the four study reaches and Marble Canyon aggregate in response to the September 2000 habitat maintenance flows (HMF). ..62

33. Graphs showing the amount of erosion and deposition at scour-chain sites.

34. Map showing erosion and deposition at the river mile 30 study site within the first day of the September 2000 habitat maintenance flows (HMF). .64

35. Time series of backwater area (A) and the number of eddies with backwaters (B). 65

\section{Tables}

1. Study site locations and geographic place names of the 19 fan-eddy complexes surveyed in March, June, August, and September 2000.

2. Descriptions of the four study reaches included in photogeologic mapping based on two sets of aerial photographs acquired before and after the September 2000 habitat maintenance flows (HMF) .......67

3. Error matrix of the agreement between areas surveyed by Northern Arizona University (NAU) and estimated by Utah State University (USU) ......................................................................................67

4. Data from scour chains installed in August 2000 and recovered in September 2000....................................68

5. Change in sediment mass during each of the five periods...........................................................................70 
6. Bed area (in $\mathrm{m}^{2}$ ) and fraction of bed area (in \%) composed of each bed-texture class before and after the September habitat maintenance flows (HMF) in the three study reaches in Marble Canyon, as determined from side-scan sonar data.

7. Area $\left(\mathrm{m}^{2}\right)$ and volume $\left(\mathrm{m}^{3}\right)$ of fine sediment at each study site, within the high-elevation-eddy, midelevation-eddy, low-elevation-eddy, and main-channel zones.

8. Percentage change in fine-sediment area and volume in each study site relative to the areas and volumes in March 2000, within the high-elevation-eddy, mid-elevation-eddy, low-elevation-eddy, and main-channel zones.

9. Volumes and rates of fine sediment either eroded or deposited in the eddy part of the fan-eddy complex at river mile 30 during the September 2000 habitat maintenance flows (HMF).

10. Average response of the bed and eddy sandbars to various flow regimes of the low summer steady flows (LSSF) in different parts of the study area.

\section{Conversion Factors}

\section{SI to Inch/Pound}

\begin{tabular}{lll}
\hline \multicolumn{1}{c}{ Multiply } & \multicolumn{1}{c}{ By } & \multicolumn{1}{c}{ To obtain } \\
\hline Length & & \\
\hline centimeter $(\mathrm{cm})$ & 0.3937 & inch (in.) \\
meter $(\mathrm{m})$ & 3.281 & foot $(\mathrm{ft})$ \\
kilometer $(\mathrm{km})$ & 0.6214 & mile $(\mathrm{mi})$ \\
\hline Area & & \\
\hline square meter $\left(\mathrm{m}^{2}\right)$ & 10.76 & square foot $\left(\mathrm{ft}^{2}\right)$ \\
\hline Volume & & \\
\hline cubic meter $\left(\mathrm{m}^{3}\right)$ & 35.31 & cubic foot $\left(\mathrm{ft}^{3}\right)$ \\
\hline Flow rate & & \\
\hline cubic meter per second $\left(\mathrm{m}^{3} / \mathrm{s}\right)$ & 35.31 & cubic foot per second $\left(\mathrm{ft}^{3} / \mathrm{s}\right)$ \\
\hline Mass & & ton, short $(2,000 \mathrm{lb})$ \\
megagram $(\mathrm{Mg})$ & 1.102 &
\end{tabular}




\title{
Streamflow and Sediment Data Collected to Determine the Effects of Low Summer Steady Flows and Habitat Maintenance Flows in 2000 on the Colorado River between Lees Ferry and Bright Angel Creek, Arizona
}

By John C. Schmidt, David J. Topping, David M. Rubin, Joseph E. Hazel, Jr., Matt Kaplinski, Stephen M. Wiele, and Sara A. Goeking'

\begin{abstract}
The low summer steady flows (LSSF) experiment of 2000 further demonstrated that spike flows released from Glen Canyon Dam redistribute sand from the channel bed and lower elevation parts of eddy sandbars to channel-margin deposits and the higher elevation parts of eddy sandbars. Unfortunately, summer 2000 was a period of unusually low tributary influx of sediment and there was little fine sediment (i.e., sand and finer material) available for redistribution. Nevertheless, the low steady flows, which held releases from the dam steady at $230 \mathrm{~m}^{3} / \mathrm{s}\left(8,100 \mathrm{ft}^{3} / \mathrm{s}\right)$, during the summer of 2000 effectively retained on the channel bed the little sediment that was supplied by tributaries, and a subsequent 4-day, $870 \mathrm{~m}^{3} / \mathrm{s}\left(30,700 \mathrm{ft}^{3} / \mathrm{s}\right)$ spike flow caused modest increases in the area of the mid-elevation zone of eddy sandbars.
\end{abstract}

\footnotetext{
${ }^{1}$ John C. Schmidt and Sara A. Goeking, Department of Watershed Sciences, Utah State University, Logan, Utah, 84322-5210. David J. Topping, Grand Canyon Monitoring and Research Center, U.S. Geological Survey, Flagstaff, Ariz. David M. Rubin, U.S. Geological Survey, Marine Geology Team, Santa Cruz, Calif. Joseph E. Hazel, Jr. and Matt Kaplinski, Department of Geology, Northern Arizona University, Flagstaff, Ariz. Stephen M. Wiele, U.S. Geological Survey, Tucson, Ariz.
} 


\section{Introduction}

Since 1992, environmental management of the Colorado River in Glen, Marble, and Grand Canyons has been mandated by the Grand Canyon Protection Act of 1992 (GCPA; title XVIII, secs. 1801-1809, of Public Law 102-575). Releases of water from Glen Canyon Dam are the primary determinant of streamflow, sediment transport, water temperature, and disturbance to aquatic and riparian ecosystems downstream from the dam. Glen Canyon Dam also blocks the delivery of sediment from the upstream watershed to reaches downstream from the dam. Beginning in 1990, specific water-release patterns at the dam have been implemented to address downstream ecological concerns (U.S. Department of the Interior, 1995; National Research Council, 1996). These releases have also provided opportunities for scientific measurements of river processes.

One such ecologically oriented water-release regime occurred between April 1 and September 30, 2000. During this period, the Bureau of Reclamation released low steady flows from the dam during the summer and released short-duration spike flows immediately preceding and following the low steady flows. The low summer releases were intended to benefit the endangered humpback chub (Gila cypha) and assist in compliance with the Endangered Species Act of 1973 (Bureau of Reclamation, 2000). A spike flow in May was intended to create "ponding and other positive habitat conditions" at the confluence of the Little Colorado River (LCR), thereby allowing young humpback chub to "more quickly grow and survive" (Bureau of Reclamation, 2000). A high spike flow in early September was intended to adversely affect nonnative fish. Although the low steady flows were only one part of a longer period of experimental dam releases, the entire period is referred to by river managers as the low summer steady flows (LSSF) experiment because both the low steady flows and two spike flows were linked by similar biological objectives.

Although the motivation behind the LSSF experiment was biological, the Physical Resources Program of the U.S. Geological Survey's (USGS) Grand Canyon Monitoring and Research Center (GCMRC) developed a sediment measurement program in cooperation with Northern Arizona University (NAU) and Utah State University (USU). The goal of this collaborative effort was to measure influx, efflux, and change in the distribution of fine sediment in Marble Canyon and the eastern part of Grand Canyon. These measurements allowed calculation of fine-sediment budgets for different periods, because

$$
\mathrm{I}-\mathrm{E}=\Delta \mathrm{S}
$$

where I is influx of fine sediment, $\mathrm{E}$ is efflux, and $\Delta \mathrm{S}$ is change in storage. In this report, we summarize the measurements that comprise these budgets and compare values of $\Delta \mathrm{S}$ computed by (1) based on field measurements of changes in the topography of fine-sediment deposits on the channel bed and along the channel margins. The study area is the river corridor between Glen Canyon Dam and USGS gaging station 09402500 (Colorado River near Grand Canyon, Ariz.; herein referred to as the Grand Canyon gaging station), located immediately upstream from Bright Angel Creek. The dam is located at river mile $-15.8^{2}$, and the gage is located at river mile 88, 167 river $\mathrm{km}$ downstream from the dam (fig. 1).

\footnotetext{
${ }^{2}$ Locations in the river corridor are assigned by river mile upstream (negative values) or downstream (positive values) from Lees Ferry, Ariz. This measurement system was created by the USGS in 1921-23. We use revised locations of this measurement system, reported to the nearest 0.1 river mile (U.S. Geological Survey, 2006).
} 


\section{Background}

\section{Study Area}

The study area consists of four parts: Glen Canyon, upper Marble Canyon, lower Marble Canyon, and upper Grand Canyon (fig. 1). Glen Canyon is that part of the river corridor between the dam and the confluence of the Colorado and Paria Rivers at river mile 0.8. Upper Marble Canyon extends to approximately river mile 40, and lower Marble Canyon extends from there to the confluence with the Little Colorado River at river mile 61.8. We use the informal term upper Grand Canyon to refer to the river segment between the LCR and the Grand Canyon gaging station.

\section{Geomorphic Framework}

The distribution of fine sediment on the bed and along the margins of the Colorado River in the study area is determined by (1) the geomorphology of the river corridor, (2) the supply of fine sediment from tributaries, and (3) water releases from Glen Canyon Dam. The sites of finesediment storage are primarily determined by river corridor geomorphology and include the bed, eddy sandbars, and channel-margin deposits. Changes in fine-sediment storage occur as changes in bed elevation, changes in the topography of sandbars and channel-margin deposits, and changes in the proportion of the bed covered by fine sediment. Extreme changes in bed elevation and composition occurred in Glen Canyon soon after the dam was completed (Pemberton, 1976; Grams and others, 2007). Many studies have shown that the total area and number of sandbars and channel-margin deposits decreased after completion of the dam (Kearsley and others, 1994; Webb, 1996).

The distribution of river deposits along the channel edge is determined by the repeating hydraulic patterns created by debris fans that exist at the mouths of most tributaries. Schmidt and Rubin (1995) defined fan-eddy complexes as the sequence of hydraulic features that occurs wherever a tributary debris fan partially blocks the flow of the river, and this pattern is similar at each fan (fig. 2). The most upstream part of each fan-eddy complex is the ponded flow upstream from the fan, where the water-surface elevation is largely determined by the hydraulic control caused by the narrow channel and elevated bed of the rapid immediately downstream. Ponding may extend upstream between a few channel widths to a few kilometers (Kieffer, 1985) and varies with discharge. Differences in channel geometry cause some rapids to be "drowned out" at high flow, whereas the degree of hydraulic control at other sites may increase at flood stage (Kieffer, 1987). The bed of the ponded backwater is a large area of potential temporary storage of fine sediment (Howard and Dolan, 1981).

Flow separation occurs immediately downstream from most rapids where the bank angle diverges abruptly from the orientation of the main flow (Schmidt, 1990). A zone of lateral recirculating flow (i.e., an eddy) exists along the bank downstream from the point of flow separation. Eddies effectively trap the suspended sediment load, and eddy sandbars composed of fine sediment typically are deposited in these zones of lateral flow recirculation. Sedimentary structures in these sandbars reflect the recirculating flow (Rubin and others, 1990, 1994).

The entire eddy sandbar is not typically exposed at base flows, and some parts of eddy sandbars are of low elevation and always submerged. One metric of change in fine sediment storage in eddies is the area of eddy sandbars emergent at base flow or the area above some reference discharge. These measurements are meaningful because eddy sandbars do not migrate downstream and are fixed in location by the channel geometry that creates flow separation. Another 
metric describing sandbar change is to compare sandbar area to the area of the entire eddy where deposition has historically occurred. This metric normalizes sandbar area because every eddy sandbar is divided by its local area of potential deposition. Because the area and length of eddies changes with flow, it is impossible to precisely define the area of potential eddy deposition without field observation at a wide range of discharges. This is impossible for a large study area. Schmidt and others (2004) proposed an objectively defined surrogate called the eddy deposition zone (EDZ). The EDZ is the composite area of each eddy where eddy sandbars have ever been emergent in any year of available aerial photography (fig. 3). The EDZ is smaller than the recirculating eddy itself because sandbars in some eddies have never been emergent at base flows in any historical aerial photograph. Schmidt and others (2004) termed the proportional area of an EDZ where an eddy sandbar occurred in a specific year a "fill ratio." The "cumulative fill ratio" of a study reach is the total area of eddy sandbars measured at one time divided by the total area of all EDZs in that reach.

The highest elevation parts of eddy sandbars sometimes merge downstream with linear banks of fine-sediment deposits that resemble flood plains (Schmidt and Graf, 1990). These "channel-margin deposits" typically have levees of low relief and form by deposition of suspended sediment as it moves away from the main flow, similar to deposits that occur on the floodplains of alluvial rivers.

A mid-channel, or bank-attached, cobble bar often exists downstream from the zone of lateral flow recirculation. The debris on this bar has been eroded from the upstream debris fan (Webb and others, 1988, 1989, 1999; Grams and Schmidt, 1999; Pizzuto and others, 1999; Larsen and others, 2004). At moderate and low discharges, flow typically passes around the margins of these cobble bars and creates a riffle.

\section{Streamflow}

The seasonal and annual fluxes of water and fine sediment passing through the study area were highly variable before completion of Glen Canyon Dam (Topping and others, 2000a). The median discharge of the Colorado River at USGS gaging station 09380000 (Colorado River at Lees Ferry, Ariz; herein referred to as the Lees Ferry gaging station) was $226 \mathrm{~m}^{3} / \mathrm{s}\left(7,980 \mathrm{ft}^{3} / \mathrm{s}\right)$ for the predam period between May 8, 1921, and March 12, 1963, and the range of flows during the year was large. The $10 \%$ exceedence flow was $1,360 \mathrm{~m}^{3} / \mathrm{s}\left(48,000 \mathrm{ft}^{3} / \mathrm{s}\right)$, and the $90 \%$ exceedence flow of $127 \mathrm{~m}^{3} / \mathrm{s}\left(4,500 \mathrm{ft}^{3} / \mathrm{s}\right)$ was an order of magnitude less (Topping and others, 2003).

Operations of Glen Canyon Dam greatly reduced the magnitude of floods and increased the magnitude of base flows. The median discharge of the Colorado River for the period between March 14, 1963, and September 30, 2000, was 74\% higher and the seasonal variation in flows was much less than during the predam period (Topping and others, 2003). The 10\% exceedence flow for the postdam period was $708 \mathrm{~m}^{3} / \mathrm{s}\left(25,000 \mathrm{ft}^{3} / \mathrm{s}\right)$, and the $90 \%$ exceedence flow was $125 \mathrm{~m}^{3} / \mathrm{s}$ $\left(4,400 \mathrm{ft}^{3} / \mathrm{s}\right)$.

The era of environmental management began in summer 1990 during an 18-mo period when dam releases varied for 2-week periods to facilitate river-scale experiments to evaluate the downstream effects of dam releases that fluctuated on a daily basis for hydropower generation (Beus and Avery, 1992). The daily range in dam releases was thereafter constrained when the Secretary of the Interior adopted "interim operating criteria" in August 1991. Dam operations were modified only slightly after the 1996 signing of the Record of Decision (ROD) of the Operation of Glen Canyon Dam Final Environmental Impact Statement (U.S. Department of the Interior, 1995). In addition to constraining the magnitude of the daily peak discharge, the "interim operating 
criteria" and ROD prohibited daytime dam releases less than $227 \mathrm{~m}^{3} / \mathrm{s}\left(8,000 \mathrm{ft}^{3} / \mathrm{s}\right)$ and nighttime releases less than $142 \mathrm{~m}^{3} / \mathrm{s}\left(5,000 \mathrm{ft}^{3} / \mathrm{s}\right)$. As a result, the magnitude of base flows increased throughout the 1990s, and flows less than the predam median discharge of $226 \mathrm{~m}^{3} / \mathrm{s}\left(7,980 \mathrm{ft}^{3} / \mathrm{s}\right)$ rarely occurred.

The ROD distinguishes two types of high-flow dam releases: (1) habitat maintenance flows (HMF), which are high steady releases that are approximately at the capacity of the powerplant, and (2) beach/habitat-building flows (BHBF), which are infrequent events exceeding powerplant capacity. The $7-\mathrm{d}$ release of $1,274 \mathrm{~m}^{3} / \mathrm{s}\left(45,000 \mathrm{ft}^{3} / \mathrm{s}\right)$ in 1996 , referred to as the 1996 controlled flood, was the first BHBF released from the dam during the era of environmental management. Spike flows at the capacity of the powerplant in May and September 2000 were HMFs.

\section{Sediment Supply and Sediment Transport}

Between 1944 and completion of the dam, the annual load of fine sediment was $57 \pm 3 x$ $10^{6} \mathrm{Mg}$ at the Lees Ferry gaging station and $83 \pm 4 \times 10^{6} \mathrm{Mg}$ at the Grand Canyon gaging station (Topping and others, 2000a). Approximately $40 \%$ and $35 \%$ of the annual fine sediment load passing the Lees Ferry and Grand Canyon gages, respectively, was sand. Thus, the average annual predam sand supply to Marble Canyon was approximately $24 \times 10^{6} \mathrm{Mg}$, and the average annual predam sand supply to the upstream end of Grand Canyon was approximately $26 \times 10^{6} \mathrm{Mg}$ (Wright and others, 2005).

After completion of Glen Canyon Dam, sand delivery to the part of Glen Canyon downstream from the dam decreased by about $99.5 \%$. Sand delivery to the upstream end of Marble Canyon decreased by about $94 \%$, and the Paria River is now the only major supplier of sand to Marble Canyon. Because some sand continues to enter the Colorado River from the LCR and smaller tributaries, sand transported past the Grand Canyon gage decreased by about 85\% (Topping and others, 2000a).

Seasonal differences in suspended-sand concentration at the Lees Ferry and Grand Canyon gaging stations were demonstrated by Topping and others (2000b) and imply that there was a 9-mo period between July and the following March when sand accumulated in the study area because more sand was delivered into Marble and upper Grand Canyons than was exported downstream (Topping and others, 2000a). Topping and others (2000a) also showed that sand only accumulated in the study area during the predam era when the discharge of the Colorado River was typically less than about $250 \mathrm{~m}^{3} / \mathrm{s}\left(8,800 \mathrm{ft}^{3} / \mathrm{s}\right)$.

The role of tributary sand supply in determining the concentration of suspended sand in the Colorado River is now greater than during the predam period. Topping and others (2000b) showed that the dominant size of the fine sediment on the bed differs by a factor of four between times immediately following tributary fine-sediment resupply and periods when there is no tributary input of sediment. These changes in bed grain size occur because the finest part of tributary-supplied sediment is winnowed from the bed by subsequent clear-water dam releases. Topping and others (2000a, 2000b) and Rubin and others (2002) showed that newly input tributary sand is likely exported past the Grand Canyon gaging station within several months because suspended-sand transport is higher when the bed is enriched with finer sediment. Transport rates subsequently decline as the bed is winnowed and coarsens.

Longitudinal changes in sand transport may cause longitudinal differences in eddy sandbar size. Wiele and others (1999) predicted that higher concentrations of suspended sand would create larger eddy sandbars for the same hydrologic event. Additionally, Schmidt (1999) showed that deposition rates during the 1996 controlled flood were larger downstream from the LCR, where 
suspended-sand concentrations were greater. Conversely, small sandbars form or net sandbar erosion occurs where the concentrations of suspended sand are low. If a particular flood has a large increase in sand transport in the downstream direction, then there might also be an associated downstream increase in the size of the eddy sandbars that are formed by that flow.

The sites of fine-sediment accumulation and evacuation may change longitudinally and with time. Sediment budgets calculated for the 1996 controlled flood suggest that the primary source of sand deposited at higher elevations in eddies and as channel-margin deposits in Marble Canyon was eroded sand from upstream eddies (Schmidt, 1999). This resulted in a net decrease in sandbar size in Marble Canyon during this flood. In contrast, the sand deposited at higher elevations in eddies in upper Grand Canyon appears to have been eroded from both upstream eddies and the channel bed. Sand storage on the channel bed and at low elevations along the channel margins is temporary, however. The sediment budgets on which these conclusions are based are subject to large error, however, and documenting the existence of changing longitudinal patterns of sediment sources and sinks was one objective of the study described herein.

\section{Dam Releases during the Study Period}

Releases from Glen Canyon Dam between April 1 and September 30, 2000, were distinguished as six periods. The durations of these periods ranged from $4 \mathrm{~d}$ to 3 mo. Before this experimental flow period, dam releases had followed the pattern of normal fluctuating-flow operations, decreasing in a stepwise manner from a relatively high range in August and September 1999 to a relatively low range in February and March 2000 (fig. 4). Releases were maintained at a steady flow of $230 \mathrm{~m}^{3} / \mathrm{s}\left(8,100 \mathrm{ft}^{3} / \mathrm{s}\right)$ from March 25 through April 5, 2000. Releases from Glen Canyon Dam were increased to $485 \mathrm{~m}^{3} / \mathrm{s}\left(17,100 \mathrm{ft}^{3} / \mathrm{s}\right)$ between April 6 and 8, and flows remained at this magnitude until May 3 when they were increased to about $870 \mathrm{~m}^{3} / \mathrm{s}\left(30,700 \mathrm{ft}^{3} / \mathrm{s}\right)$. These high releases were maintained until May 7. For purposes of this report, the period before the May HMF is referred to as Period 1 and the May HMF is referred to as Period 2. The beginning of Period 1 varies in this report. In the discussion of flow and sediment transport, flows beginning on August 15, 1999, are considered as part of Period 1 to place this period within a broader context of river processes during normal dam operations. April 1, 2000, is considered the beginning of Period 1 for other components of the study.

During Period 3, dam releases consisted mostly of steady releases of $480 \mathrm{~m}^{3} / \mathrm{s}\left(17,000 \mathrm{ft}^{3} / \mathrm{s}\right)$, followed by $5 \mathrm{~d}$ of steady releases of $540 \mathrm{~m}^{3} / \mathrm{s}\left(19,100 \mathrm{ft}^{3} / \mathrm{s}\right)$ that then decreased in a stepwise manner to $230 \mathrm{~m}^{3} / \mathrm{s}\left(8,100 \mathrm{ft}^{3} / \mathrm{s}\right)$ on May 31 . Between June 1 and September 4 , dam releases were held constant at $230 \mathrm{~m}^{3} / \mathrm{s}\left(8,100 \mathrm{ft}^{3} / \mathrm{s}\right)$; this period is referred to as Period 4 . Period 5 , the September HMF, extended from September 5 through September 8, during which dam releases were increased to a steady $870 \mathrm{~m}^{3} / \mathrm{s}\left(30,700 \mathrm{ft}^{3} / \mathrm{s}\right)$ for $4 \mathrm{~d}$. Dam releases were reduced to base flows on September 9, when Period 6 began. The maximum discharge of the HMFs in Periods 2 and 5 was approximately $30 \%$ less than the maximum peak discharge of the 1996 controlled flood.

\section{LSSF Hypotheses and Study Design}

A comprehensive science plan was developed to evaluate the effects of the LSSF experiment on various components of the Colorado River ecosystem downstream from Glen Canyon Dam (Fritzinger and others, 2000). Only the sediment-studies part of this plan and associated guiding hypotheses are described herein. 


\section{Study Plan}

Changes in fine-sediment storage were determined in four study reaches, each approximately 3-8 km long, using a combination of reach-length aerial-photographic analyses and detailed ground surveys at selected study sites. These changes in fine-sediment storage were measured for Period 4 and Period 5. One purpose of this research program was to determine whether the distribution of sites of sediment storage and evacuation varied longitudinally. During Period 4, the location and magnitude of sediment storage change was expected to vary in relation to local and reach-scale channel geometry and distance downstream from those tributaries that delivered fine sediment during or immediately before the study period. During the September HMF (Period 5), the location and magnitude of sediment storage change was expected to vary in relation to bed conditions at the onset of this spike flow and in relation to the downstream increase in sediment flux that was anticipated would exist during the HMF.

Data collected were sufficient to compute fine-sediment budgets for Marble and upper Grand Canyons for Periods 4 and 5. To measure the influx of discharge and sediment supplied by tributaries, gaging stations were operated on the Paria River, House Rock Wash, and the LCR, where suspended-sediment samples were also collected. The proportion of the fine-sediment flux deposited at high elevations was estimated in Marble Canyon and in a reach in Grand Canyon immediately downstream from the LCR during Period 5. Various traditional and nontraditional methods were used to make measurements of changes in the volume and characteristics of fine sediment stored on the bed, in eddies, and in channel margins. This research approach provided the opportunity to evaluate how these methods could be integrated in the calculation of sediment budgets and to determine the level of precision and accuracy appropriate in measuring each component of such a budget.

Sediment budgets for Marble Canyon that arose from this study were compared to those of Schmidt (1999) and Hazel and others (2000). These sediment budgets, including those arising from this study, were subsequently refined using topographic-based and grain-size-based approaches to constructing sediment budgets in Hazel and others (2006). Evaluations were conducted to determine whether the proportion of the total sediment flux deposited at higher elevations differed significantly between the 1996 controlled flood and the September 2000 HMF. These data are crucial for river managers because they quantify the "cost" of restoration floods (i.e., the fine sediment exported from Marble Canyon) in relation to the "benefit" of these floods (i.e., the volume of newly deposited fine sediment that benefits target species or is of value for riparian habitat, camping, or aiding in the preservation of archaeological sites). Lastly, the sediment budget for Period 4 was compared to the seasonal sediment budgets of Topping and others (2000a) to determine if flows of $230 \mathrm{~m}^{3} / \mathrm{s}\left(8,100 \mathrm{ft}^{3} / \mathrm{s}\right)$ were sufficiently low to cause net accumulation of fine sediment on the channel bed and in the lower elevation parts of eddies in Marble Canyon during, and for extended periods following, tributary inputs of fine sediment. The potential for seasonal to multiyear accumulation of fine sediment downstream from Glen Canyon Dam underlies the preferred alternative described by the U.S. Department of the Interior (1995).

Thus, the sediment study plan and methods were guided by several expectations about river behavior. 
Hypothesis 1: Accumulation of Sediment in Marble Canyon and Upper Grand Canyon during Period 4

The steady flows less than $250 \mathrm{~m}^{3} / \mathrm{s}\left(8,800 \mathrm{ft}^{3} / \mathrm{s}\right)$ released during Period 4 were expected to result in accumulation of sediment in the study area, based on the findings of Topping and others (2000a). The study goals were to measure the inflow and export of fine sediment and to measure changes in the size of fine sediment deposits. These measurements made it possible to determine the magnitude of accumulation that occurred upstream and downstream from the LCR, to determine the locations of accumulation of fine sediment, and to determine whether these locations differed in a systematic way downstream. Overall, it was expected that $\Delta S$ in (1) would be positive during Period 4.

\section{Hypothesis 2: Evacuation of Fine Sediment from Marble Canyon and Upper Grand Canyon} during Normal Dam Operations

Flows higher than $250 \mathrm{~m}^{3} / \mathrm{s}\left(8,800 \mathrm{ft}^{3} / \mathrm{s}\right)$ were hypothesized to result in net export of sand from the study area, based on the same logic described in the preceding expectations. Thus, it was expected that $\Delta \mathrm{S}$ would be negative for other periods.

Hypothesis 3: Relative Effectiveness of High Flows in Depositing Eddy Sandbars and Creating Backwaters

In light of the anticipated accumulation of fine sediment during Period 4 , the transport of suspended sediment was expected to be greater and the grain size of the suspended sediment was expected to be finer in September than in May. Therefore, eddy sandbars were expected to be larger immediately after the September HMF than after the May HMF.

Hypothesis 4: Evaluation of the Relative Roles of Sediment Transport, Reach Scale Geometry, and Local Site Geometry in Determining the Magnitude and Location of Deposition and Erosion during High Flows

Detailed measurements of changes in sediment storage within short reaches provided the opportunity to describe how these changes differ longitudinally as the sediment flux presumably increased downstream. The role of reach-scale channel geometry in controlling the location of fine-sediment erosion and deposition was also evaluated.

Hypothesis 5: Evaluation of Rubin and Topping's (2001) Metric of Relative Bed-sediment Coarseness $(\beta)$ to Describe Average System Behavior

Rubin and Topping (2001) suggested that $\beta$ can be calculated from sedimenttransport measurements and be used as a measure of upstream changes in fine sediment accumulation. $\beta$ is a nondimensional measure of the average bed-surface grain-size that interacts with the suspended sand in the flow. $\beta$ uses the concentration and grain size of the sand in suspension to compute the average upstream grain size of the sand on the bed. All measurements necessary to calculate 
$\beta$ and to determine the upstream changes in storage that cause $\beta$ to change were collected.

\section{Methods}

\section{Tributary Influxes and Sediment Transport of the Colorado River}

Sediment influxes were measured on the Paria River, House Rock Wash, and the LCR. Stream-flow gaging stations on the Paria River and LCR were in place before the beginning of this study. Gaging of House Rock Wash began on July 25, 2000, when a downward looking acoustic stage gage was installed. This tributary is the largest entering the Colorado River between the Paria River and the LCR. Because of the remoteness and flashiness of House Rock Wash, discharge measurements were not made there, and the relation between stage and discharge was computed using the USGS multidimensional surface-water modeling system (McDonald and others, 2001).

Between August 15, 1999, and October 31, 2000, 96 suspended-sediment measurements were made near USGS gaging station 09382000 (Paria River at Lees Ferry, Ariz., herein referred to as the Paria River gaging station), and 48 suspended-sediment measurements were made near USGS gaging station 09402000 (Little Colorado River near Cameron, Ariz., herein referred to as the LCR gaging station). Of the samples collected near the Paria River gaging station, 17 were collected by the equal-width increment (EWI) method (Edwards and Glysson, 1988), 77 were dip samples, and 2 were collected by an automatic pump sampler. Of the samples collected near the LCR gaging station, 3 were collected by either the EWI or equal-discharge increment (EDI) methods, 2 were dip samples, 38 were collected by an automatic pump sampler, and 5 were collected by a U-59 single-stage sampler. Five suspended-sediment samples were collected in House Rock Wash between July 25 and October 31, 2000, using a U-59 single-stage sampler.

Suspended-sediment concentration and grain size in the Colorado River were determined from cross-sectionally integrated suspended-sediment measurements. Between August 15, 1999, and September 30, 2000, 238 measurements were made at USGS gaging station 0938100 (Colorado River above Little Colorado River near Desert View, Ariz.; herein referred to as the Lower Marble Canyon gaging station) located at river mile 61.4, and 340 measurements were made at the Grand Canyon gaging station. Of the samples collected at the Lower Marble Canyon gaging station, 79 were collected by the EWI method using a D-77 bag sampler and 159 were collected by the EDI method using a D-77 bag sampler. Of the samples collected at the Grand Canyon gaging station, 7 were collected by the EWI method using a D-77 bag sampler and 333 were collected by the EDI method using a D-77 bag sampler. In addition to the samples collected at these two gaging stations, 12 cross-sectionally integrated suspended-sediment measurements were made with a D-77 bag sampler using the EWI method near river mile 30.2 just before, during, and immediately after the September HMF.

To determine longitudinal changes in the spatial distribution of channel and eddy sources of suspended fine sediment before, during, and after Period 4, suspended-sediment samples were collected downstream from Lees Ferry on river trips in May, July, and September 2000. Between May 11 and May 16, 21 surface dip samples were collected in the center of the channel. Dam releases during this river trip were $480 \mathrm{~m}^{3} / \mathrm{s}\left(17,000 \mathrm{ft}^{3} / \mathrm{s}\right)$. Between July 26 and July 31,18 surface dip samples were collected in the center of the channel. Dam releases during this trip were $230 \mathrm{~m}^{3} / \mathrm{s}$ $\left(8,100 \mathrm{ft}^{3} / \mathrm{s}\right)$. Between September 6 and 8, 91 single-vertical depth-integrated samples and 37 surface dip samples were collected in the center of the channel using a sampling scheme wherein the same parcel of water was tracked between Lees Ferry and river mile 100 during $3 \mathrm{~d}$ of traveling 
at the mean flow speed and camping for only those hours when navigation was not feasible because of darkness. Because the goal of the trip was to sample the same water parcel as it traveled downstream, this sampling trip is hereafter referred to as the "Lagrangian sampling trip."

\section{Characteristics and Changes in the Area of the Bed Covered by Fines and the Size of Fine Sediment on the Bed}

Changes in the area of the bed covered by fine sediment were determined from towed sidescan sonar surveys conducted by R.J. Anima before and after the September HMF (Wong and others, 2003). Details of the side-scan sonar system used in these surveys are described by Anima and others (1998). Before and after the September HMF, side-scan sonar data were collected in three reaches in Marble Canyon: the Lees Ferry, Redwall Gorge, and Point Hansbrough reaches (fig. 1). These data were positioned using a handheld Global Positioning System (GPS) receiver and reference to aerial photographs. The spatial accuracy of the side-scan sonar data was subsequently improved by matching shoreline features present in the side-scan sonar data with equivalent features in 2002 orthorectified digital aerial photography. Once an adequate number of ground control points were located in the side-scan sonar data, several geometric correction algorithms were applied using standard GIS image-processing software. The effectiveness of each algorithm for producing an image that most closely matched the shoreline features in the aerial photography was compared, and the rubber-sheeting algorithm was found to produce the best results. Ground control point positioning was only possible along the edges of the side-scan sonar data, where the shoreline was detectable. Not all images contained complete shoreline features (e.g., the side-scan sonar swath captured only one shore, or neither shore was visible in places where the river was wider than the sample swath). In these situations, it was difficult or impossible to identify the true locations of the features observed in the side-scan sonar data, and some river segments contained no ground control points. This is not desirable when using the rubber-sheeting model (or most other geometric correction models), and as expected, it produced distortions and some data loss.

The grain size of bed sediment was monitored using three techniques: physical samples, observational samples, and calculated indices of bed sediment size. Sediment samples were collected with a pipe dredge, and an underwater video microscope recorded observations of surficial sediment. Indices of grain size were calculated from the concentration and grain size of suspended sediment at the Grand Canyon gaging station using the $\beta$ technique of Rubin and Topping (2001).

Using an underwater microscope system composed of a microscopic lens installed on a digital video camera and housed in a heavy pressure case (Chezar, 2001; Rubin and others, 2006, in press), several thousand in situ images of surficial bed sediment were collected. The entire system was lowered to the riverbed using a winch. A digital video recording console on the surface vessel was used to acquire and record images of the riverbed. The mean grain size of each sample was determined by viewing digital videotapes of the bed images on a computer using a video-editing program. We extracted frames that showed usable images of bed sediment, and frames were considered usable when no sediment was blurred in the image. Blurring is caused by movement of the camera owing to currents, turbidity, or change in boat position. The selected usable frames were converted from picture files to text files to obtain grain-size data. A spatial autocorrelation algorithm (Rubin and others, 2001; Rubin, 2004) was used to process the text files and determine the mean grain size of each sample. Samples were aggregated into 15 groups that distinguished samples collected before and after the September HMF, and the mean grain size was computed for 
each of the 15 groups before and after the September HMF. Values of $\beta$ were compared to observed systemwide trends in suspended sediment and bed sediment to evaluate this metric's ability to describe average system behavior.

\section{Changes in the Topography of Fine-Sediment on the Bed, in Eddy Sandbars, and in Channel-margin Deposits}

\section{Changes Measured by Ground Surveys and Bathymetry}

The topography of eddy sandbars, channel-margin deposits, and the bathymetry of the bed were measured in March, June, August, and September 2000 to evaluate changes in location and magnitude of fine-sediment storage in parts of 19 fan-eddy complexes. One measurement site was in Glen Canyon, 13 sites were in Marble Canyon, and 5 sites were in upper Grand Canyon (fig. 1). Measurements bracketed both HMFs. The volume and area of fine sediment above the stage of specific reference discharges were compared. Kaplinski and others (1995) and Hazel and others (1999) described annual and more frequent surveys at the same long-term study sites between July 1991 and February 1997. Study site reference numbers indicate river mile location (table 1).

The primary area of interest within each site was the eddy sandbars immediately downstream from each constriction. Nearby channel-margin deposits and the main-channel bed immediately downstream from each constriction and directly offshore from surveyed eddy sandbars were also measured at most sites. For computational purposes, the dividing line separating the main channel and eddy was taken as the topographic base of the eddy sandbar. This dividing line typically occurs offshore from the location of the streamline dividing downstream channel flow and recirculating flow.

Surveys of terrestrial and shallow subaqueous topography were conducted using electronic total stations and conventional survey techniques. River bathymetry was surveyed using highresolution single-beam and multibeam echo sounders (Kaplinski and others, 2000); although, there were technical problems with the multibeam system during the June surveys that prevented bed topography from being measured at most sites.

The repeat surveys allowed precise assessment of topographic change. As many as 2,000 ground points, between $2 \times 10^{4}$ and $3 \times 10^{4}$ single-beam bathymetric points, and between $8 \times 10^{6}$ and $10 \times 10^{6}$ multibeam bathymetric points were collected at each site to define the topography. The point data have a horizontal error of less than $0.25 \mathrm{~m}$ and vertical error that varies from $5 \mathrm{~cm}$ or less for points acquired with a total station to $10 \mathrm{~cm}$ or less for bathymetric points. Point data were referenced, in meters, to established survey marks with the Grand Canyon Monitoring and Research Center's geodetic control network. The network references the National Spatial Reference System (Zilkoski and others, 1997) and uses the 1983 Arizona State Plane Coordinate System, central zone.

Topographic surfaces and change detection at each site were generated using surface modeling software. Single-beam and multibeam point data were resampled at 2-m intervals, and the multibeam data were converted to a 2 -m point grid derived from a triangulated irregular network (TIN) using the Delaunay method of triangulation. The combined ground-based and bathymetric data typically corresponded to an average density of one point per 1 to $5 \mathrm{~m}^{2}$. These combined points were used to calculate a TIN surface for both terrestrial and subaerial portions of each of the 19 fan-eddy complexes. Fine-sediment volumes below the $227 \mathrm{~m}^{3} / \mathrm{s}\left(8,000 \mathrm{ft}^{3} / \mathrm{s}\right)$ stage were determined by subtracting the measured values from a minimum surface TIN, which was derived 
from a regularly spaced grid of minimum point values generated from a 10-yr dataset containing as many as 25 surveys at each study site (Hazel and others, 2006).

We computed fine-sediment storage changes in eddy sandbars for three elevation zones related to the stages of three types of dam releases. The high-elevation zone is emergent above a flow of $708 \mathrm{~m}^{3} / \mathrm{s}\left(25,000 \mathrm{ft}^{3} / \mathrm{s}\right)$ and is only inundated by BHBFs and some HMFs. The midelevation zone is the area inundated by flows of $227\left(8,000 \mathrm{ft}^{3} / \mathrm{s}\right)$ to $708 \mathrm{~m}^{3} / \mathrm{s}\left(25,000 \mathrm{ft}^{3} / \mathrm{s}\right)$, the typical operating range for Glen Canyon Dam during most months. The low-elevation zone is below the stage of $227 \mathrm{~m}^{3} / \mathrm{s}\left(8,000 \mathrm{ft}^{3} / \mathrm{s}\right)$ and is always inundated during the typical flow regime. This zone includes deeper, continuously inundated portions of the eddy and main channel. The elevations for the stage of each reference discharge were derived from previously determined stagedischarge relationships for each site (Hazel and others, 1999). The high-elevation zone is equivalent to the postdam flood deposits and the mid-elevation zone is equivalent to the fluctuating-flow deposits of Schmidt and others (2004).

The methods described here permitted detection of changes in sediment storage, as well as analyses of sediment transfer among elevation zones. Changes in area and volume were normalized and expressed as a percentage of the topography surveyed in March 2000, using the following formula.

$$
\% \text { change }=100 *\left[\left(\mathrm{~V}_{\mathrm{Tx}}-\mathrm{V}_{\mathrm{Tx}+1}\right) / \mathrm{V}_{\mathrm{i}}\right] \text {, }
$$

where $V_{T x}$ is the volume or area at time $\mathrm{x}, V_{T x+1}$ is the volume or area at time $\mathrm{x}+1$, and $V_{i}$ is the volume or area in March. Areas are reported for the mid-elevation and high-elevation zones only. Low-elevation eddy and main channel areas did not change appreciably.

Direct comparison of topographic changes caused by the May and September 2000 HMFs was problematic because the time interval between the surveys bracketing the May HMF (conducted in March and June) was much greater than that for the September HMF. The maximum time interval between the pre-HMF (March) survey at a study site and the onset of the May HMF was $46 \mathrm{~d}$, and the maximum interval between the end of the May HMF and the post-HMF (June) survey at a study site was $34 \mathrm{~d}$. During this period, there were $24 \mathrm{~d}$ of steady, moderately high discharge at $487 \mathrm{~m}^{3} / \mathrm{s}\left(17,200 \mathrm{ft}^{3} / \mathrm{s}\right)$ before the May HMF and $23 \mathrm{~d}$ of steady discharge (also at 487 $\left.\mathrm{m}^{3} / \mathrm{s}\right)$ after the HMF, followed by the 3 -mo period of steady flow at $230 \mathrm{~m}^{3} / \mathrm{s}\left(8,100 \mathrm{ft}^{3} / \mathrm{s}\right)$ that began June 1. Thus, considerable change in the deposits at the study sites may have occurred that was unrelated to the May HMF. In contrast, the September HMF was immediately preceded and followed by the low, steady discharge of $230 \mathrm{~m}^{3} / \mathrm{s}$, which resulted in minimal modification of the deposits of fine sediment at the study sites, and the time interval between measurements was small.

\section{Daily Changes in Sand Storage as Measured by Ground Surveys at River Mile 30.7}

The eddy sandbar and nearby channel at river mile 30.7 were surveyed daily during the September HMF to examine daily and hourly rates of topographic change. This eddy is located in a relatively narrow part of Redwall Gorge in upper Marble Canyon. The area of the eddy within the study boundary is $8,523 \mathrm{~m}^{2}$, and it is one of the largest in the local area (Schmidt and others, 2004). A pre-HMF survey was conducted on September 4, when the discharge was about $237 \mathrm{~m}^{3} / \mathrm{s}(8,400$ $\mathrm{ft}^{3} / \mathrm{s}$ ). The site was surveyed three times on September 5 , with the first survey occurring as the flow increased from about $538 \mathrm{~m}^{3} / \mathrm{s}\left(19,000 \mathrm{ft}^{3} / \mathrm{s}\right)$ to $722 \mathrm{~m}^{3} / \mathrm{s}\left(25,500 \mathrm{ft}^{3} / \mathrm{s}\right)$. The rising limb of the HMF arrived at approximately 5:30 a.m. on September 5 (fig. 4) and took about $7 \mathrm{~h}$ to reach peak discharge, a rate of approximately $91 \mathrm{~m}^{3} / \mathrm{s}\left(3,200 \mathrm{ft}^{3} / \mathrm{s}\right)$ per hour. The second survey occurred when the flow reached its maximum stage. The total stage change during the rising limb of the HMF was 
$3.7 \mathrm{~m}$ (12 ft) (fig. 5). The site was surveyed once more that day, and surveys were repeated twice per day thereafter. The post-flood survey was conducted on September 9, when flow had returned to about $233 \mathrm{~m}^{3} / \mathrm{s}\left(8,200 \mathrm{ft}^{3} / \mathrm{s}\right)$. The longest interval between surveys was $18 \mathrm{~h}$. Volumes were calculated for the entire eddy area.

\section{Aerial Photograph Analysis of Eddy Sandbars and Channel-margin Deposits}

The area of fine sediment in the mid-elevation zone was mapped from aerial photographs in four study reaches covering $21.4 \mathrm{~km}$ of the river before and after the September HMF. These study reaches (table 2) were shorter than and totally encompassed by the $55 \mathrm{~km}$ previously mapped by Schmidt and Leschin (1995), Schmidt and others (1999), Sondossi (2001), and Sondossi and others (2002). These earlier studies described the distribution of fine sediment for several years between 1984 and 1997, including changes in the area of fine sediment caused by the 1996 controlled flood (Schmidt, 1999).

The cumulative size distributions of EDZs in the longer study reaches mapped in previous studies were compared with those of the shorter study reaches mapped in this study to evaluate whether the distributions were similar between these two datasets. Similarity is a prerequisite for comparisons of the 2000 data with data from previous years. The cumulative size distributions of eddies within these two datasets (fig. 6) were not similar in the Lees Ferry and Point Hansbrough study reaches. Thus, revised metrics for the shorter study reaches were computed for all the years presented in previous studies.

Interpretations were made of photographs acquired between August 29 and 31 and between September 15 and 18, 2000, when discharge was $227 \mathrm{~m}^{3} / \mathrm{s}\left(8,000 \mathrm{ft}^{3} / \mathrm{s}\right)$. These photographs were provided by the GCMRC as 18-cm resolution, black-and-white, digital imagery. The distribution of fine sediment was delineated from both photographic series using on-screen digitizing methods in ArcInfo. Shadows at some sites prevented unambiguous identification of the boundary between water and wet sand, and survey data in these places were used to aid in mapping the edge of water. Map units were similar to those defined by Schmidt and Leschin (1995), Schmidt (1999), and Schmidt and others (2004). We differentiated between channel-margin deposits and eddy sandbars based on the criteria of Schmidt (1990), Rubin and others (1990), and Schmidt and Rubin (1995).

GIS databases that include separate data layers obtained from different years of aerial photographs may contain several types of errors, including mapping and interpretation errors, spatial transformation errors, and errors in change-detection algorithms. The first two sources of error can occur in any specific data layer, whereas the other sources of error emerge in comparing the distribution of deposits among different years. The accuracy and precision of the maps produced in this study were estimated in two ways. First, the estimation of error within each data layer was quantified by Schmidt and others (2004), who compared a remote-sensing approach for delineating deposits in the mid-elevation zone with the extent of these deposits surveyed with total stations at 13 eddy sandbars in Marble and upper Grand Canyons. The error was assumed to be the same as those calculated by Schmidt and others (2004), since the methods used here were the same. To estimate the accuracy of the algorithm for interpreting change among data layers, areas where the algorithm predicted erosion, no change, or deposition were compared with the areas surveyed at seven sites.

A major objective of this study was the detection of temporal changes in the distribution and size of eddy sandbars and channel-margin deposits. Thus, the area of eddy sandbars and channel-margin deposits were measured, and fill ratios were determined. Absolute changes in eddy sandbars were determined by counting the number of eddy sandbars that significantly increased, 
did not change, or significantly decreased in area between August and September 2000.

Significance in these calculations was defined as a change greater than $200 \mathrm{~m}^{2}$, which represents the minimum detectable change of our methods. We also determined the mean and median size of eddy sandbars in each reach in each year of photography, the fill ratio of each EDZ in each reach, and the reach cumulative fill ratio. Net normalized aggradation (NNA) was defined as

$$
N N A=\left(A_{d}-A_{e}\right) / A_{E D Z}
$$

where $A_{d}$ is the area of significant deposition during a time period, $A_{e}$ is the area of significant erosion during the same time interval, and $\mathrm{A}_{\mathrm{EDZ}}$ is the area of the eddy deposition zone (Schmidt and others, 1999). Schmidt and others (2004) provide an extensive explanation of these metrics.

Robustness of the analyses used in this study was also evaluated. The overall accuracy of the algorithms used to compare the areas of sandbars before and after the September HMF was $64.1 \%$ (table 3 ). The off-diagonal of the error matrix in table 3, which includes areas where deposition occurred yet the algorithm predicted erosion $(0.4 \%$ of the total area) and vice versa $(0.1 \%$ of the total area), indicates that the algorithm did not always detect small amounts of erosion or deposition but rarely produced predictions opposite to the actual change. This indicates that the algorithm did not detect many of the small-scale changes in elevation measured by detailed ground surveys.

\section{Assessment of Reworking in Eddy Sandbars Using Scour Chains}

In August, 67 scour chains were installed to assess the amount of scour and fill at 18 sites during the September HMF. Each site consisted of two to four transects, with three to four chains comprising each transect (table 4). Transects were oriented perpendicular to the local edge of water at $878 \mathrm{~m}^{3} / \mathrm{s}\left(31,000 \mathrm{ft}^{3} / \mathrm{s}\right)$ and extended toward the center of the eddy. The location of each chain was surveyed in August and September before and after the HMF. Chains were $1 \mathrm{~m}$ long.

\section{Assessment of Changes in Backwater Area Among Years}

Areas of ponded flow shoreward from emergent sandbars, such as the inundated but stagnant flow area of flooded eddy return-current channels, were delineated on aerial photographs taken before and after the September HMF. These areas are locally called "backwaters" by aquatic ecologists working in Grand Canyon, and that term is used here. Thus, these backwaters are not the same as the areas of mainstem flow ponded upstream from debris fans in fan-eddy complexes. The size and distribution of backwaters as depicted on aerial photographs were mapped for the flow conditions at the time the photographs were taken. Backwaters were defined as those areas enclosed by shoreline on three sides and only open to exchange of flow with the main current at one end of the embayment. The line drawn from the edge of the sandbar that forms the streamward side of the embayment was drawn at an angle of approximately $45^{\circ}$ to the mean current direction (fig. 7). Backwaters were differentiated between those whose opening was oriented upstream and those oriented downstream. 


\section{Results}

\section{Spatial and Temporal Trends in Discharge and Suspended Sediment}

\section{Measurements of Discharge and Suspended Sediment in Tributaries}

There was little inflow from tributaries during summer and fall 2000, and the hydrographs of the four mainstem gaging stations did not differ greatly from that measured at the dam (fig. 8). Small differences in discharge between the Lees Ferry and Lower Marble Canyon gaging stations reflect small inflows from the Paria River (fig. 9A), House Rock Wash (fig. 9C), and other small tributaries in Marble Canyon. Inflow from the LCR was below normal for the study period (fig. 9B). The largest inflows during the study period occurred after August 15 well downstream of the study area, between the Grand Canyon gaging station and USGS gaging station 09402400 (Colorado River above Diamond Creek near Peach Springs, Ariz.), which is located approximately $224 \mathrm{~km}$ downstream from the Grand Canyon gaging station (compare fig. 8C and 8D). Although the LSSF study design anticipated that substantial tributary sediment would be supplied to the Colorado River during Period 4, there was little inflow of suspended sediment from any of the tributaries (Figs. 10, 11, and 12).

\section{Trends in Suspended Sediment in the Colorado River during the May and September HMFs}

Comparison of the suspended-sediment data collected at the Lower Marble Canyon and Grand Canyon gaging stations during the two HMFs (fig. 13) suggests that the upstream sand supply in Marble Canyon during the May HMF was greater than during the September HMF. Though the concentrations of suspended silt and clay during the two HMFs were comparable at the Lower Marble Canyon gaging station (fig. 14A), the concentration of suspended sand was approximately $30 \%$ lower during each day of the September HMF than during each day of the May HMF (fig. 14B). This was true despite the fact that suspended sand was slightly finer during the latter portion of the September HMF than during the May HMF (fig. 14C). Observations made during the Lagrangian sampling trip and subsequent observations in spring 2001 suggests that small-scale flooding occurred on Nankoweap and Kwagunt Creeks, two small tributaries that enter the Colorado River in Marble Canyon between the Point Hansbrough and Tapeats Gorge study reaches (fig.1), during the latter portion of the September HMF, and these tributaries probably supplied the finer-grained sediments at this time. While there was less sand in suspension in Marble Canyon during the September HMF, approximately $80 \%$ of the sand that was eroded from Marble Canyon during the September HMF was derived from sources upstream from river mile 30. Furthermore, the sand in suspension was much coarser at river mile 30 than it was at either the Lower Marble Canyon or Grand Canyon gaging stations during each day of the September HMF (fig. 14C). The differences between the May and September HMFs were less pronounced at the Grand Canyon gaging station than at the Lower Marble Canyon gaging station. After day one of the September HMF, the upstream supply of sand appears to have been comparable during both events, and the upstream supply of silt and clay actually increased temporarily during day two of the September HMF in response to upstream tributary activity.

As the upstream supply of sediment became depleted during the May and September HMFs, the suspended sediment coarsened over time while the concentration of suspended sediment decreased. This process was observed everywhere suspended sediment was measured during the two HMFs, as was the case during both the 1996 controlled flood (Rubin and others, 1998; Topping 
and others, 1999; Topping and others, 2000b) and an HMF in November 1997 (Topping and others, 2000b). Coarsening of the suspended sediment over time during these two HMFs occurred because of both a decrease in the concentration of silt and clay and a coarsening of the sand in suspension.

\section{Comparison of the Longitudinal Patterns of Suspended Sediment in May, July, and September}

Analysis of the surface dip samples collected in May, July, and September indicate that the pattern of the downstream increase in suspended sand was similar during all three periods, with a rapid increase in concentration at the mouth of the Paria River and a more gradual increase in suspended-sand concentration from the mouth of the Paria River downstream (fig. 15A). Because no substantial new tributary sand was supplied to the Colorado River during any of these sampling trips, this downstream increase in suspended-sand concentration reflected the progressive erosion of sand from the eddies and channel in the downstream direction during each period. During the May and July trips, approximately half of the sand exported past the Lower Marble Canyon gaging station was eroded from the upstream half of Marble Canyon. During the September HMF, approximately $80 \%$ of the sand exported from Marble Canyon was eroded from the upstream half of Marble Canyon.

Analysis of the suspended silt and clay data yields a similar result, with the exception being the July trip, when larger tributary effects on the silt and clay concentrations were evident immediately downstream from the Paria River and LCR (fig. 15B). During all three trips, roughly half of the suspended silt and clay that was exported from Marble Canyon was from the upstream half of Marble Canyon.

\section{Lagrangian Sampling Trip during the September HMF}

Because the goal of this river trip was to repeatedly sample the same parcel of water moving downstream on each of the $3 \mathrm{~d}$, sampling did not begin on day one because we anticipated a rapid temporal decrease in suspended-sediment concentration at the onset of the flood. Such a rapid decrease in concentration would increase the error associated with imperfect tracking of the same parcel of water as it moved downstream.

After an initial rapid increase in the concentration of suspended sand between Lees Ferry and river mile 10, suspended-sand concentrations gradually increased further downstream. Slight decreases were measured between the last measurement of an evening and the first measurement of the next morning (fig. 16A), because the parcels of water sampled on different days were different parcels of water. Similarly, the concentration of suspended silt and clay gradually increased in the downstream direction, and there was a rapid increase in suspended silt and clay concentration immediately downstream from the LCR. As the concentration of suspended sand increased downstream, the grain size of the suspended sand got finer (fig. 16B). Comparison of the data collected throughout the Lagrangian sampling trip, at river mile 30, and at the Lower Marble Canyon gaging station suggests that more than half of the sand that was eroded upstream from river mile 30 during the September HMF was eroded between the Paria River and river mile 10.

\section{Computation of the Mass-Balance Sediment Budgets}

Using both the model of Topping (1997) and suspended-sediment measurements, the cumulative fine-sediment supply for the Paria River was computed for the entire study period. Tributary influxes of fine sediment from the other two measured tributaries, House Rock Wash and 
the LCR, were computed using suspended-sediment measurements only (fig. 17A). The cumulative fine-sediment export past the Lower Marble Canyon and Grand Canyon gaging stations was computed using measurements of suspended-sediment concentration (fig. 17B). Cumulative finesediment influxes to and effluxes from the study area were thus computed for Periods 1 through 5 .

\section{Fine-sediment Input to Marble Canyon}

Instantaneous loads of sand, silt, and clay in the Paria River computed using the model of Topping (1997) compared favorably with those measured during the two periods of historical daily sediment data, October 1947-September 1976 and July-December 1983, with the model-predicted sand loads being better than the model-predicted silt and clay loads (Topping, 1997). Uncertainties used in the model computations for the period of August 15, 1999, through October 31, 2000, were $20 \%$ for sand and 50\% for silt and clay (fig. 17A). Comparison of the model-predicted and measured instantaneous sand loads and silt and clay loads indicate that these uncertainties are reasonable (fig. 18A, B).

Data collected at the gaging station on House Rock Wash were used to estimate the supply of sand and the supply of silt and clay from the smaller tributaries during Periods 4 and 5. Data collected at gaging stations installed subsequent to this study during 2001-02 on other small tributaries suggest that House Rock Wash contributes between 1.5 and 2 times the amount of fine sediment to Marble Canyon than does the combined influx of Badger Creek, Tanner Wash, North Canyon Wash, and Shinumo Wash (D.J. Topping, unpubl. data). Together with House Rock Wash, these small tributaries comprise approximately $55 \%$ of the tributary drainage basin area to Marble Canyon downstream from the Paria River. Observations made in these small tributaries in July 2000 and measured streamflow at the Lower Marble Canyon gaging station together indicate that no substantial floods occurred before July 2000 on Badger Creek, Tanner Wash, or Shinumo Wash. One large flood probably occurred in June on North Canyon Wash, and one moderate flood occurred before July 25 on House Rock Wash. To account for these tributary inputs, the sand loads, and silt and clay loads computed for House Rock Wash were doubled, with uncertainties assumed to be $50 \%$.

\section{Fine-sediment Export from Marble Canyon}

Sand export and silt and clay export from Marble Canyon during Periods 1 through 5 were computed by multiplying the measured concentrations of suspended sediment in these size classes at the Lower Marble Canyon gaging station by the discharge of water; uncertainties of $20 \%$ were assumed (fig. 17B). Only one suspended-sediment measurement was made during the period between October 1999 and March 2000; measurements of suspended-sand and suspended-silt and clay concentration observed at the Grand Canyon gaging station were thus used to estimate suspended-sediment concentrations at the Lower Marble Canyon gaging station during this period. In addition to computing the sediment efflux from Marble Canyon, the suspended-sediment data collected near river mile 30 were used to compute the sediment export from the upstream half of Marble Canyon during the September HMF.

\section{Sand Input to Upper Grand Canyon}

During each of the five periods, the sand input to upper Grand Canyon was computed by combining the computed sand efflux past the Lower Marble Canyon gaging station, including uncertainties, with an estimate of the sand supplied by the LCR (fig. 17A). A suspended-sand rating 
curve was developed to estimate the suspended-sand concentration as a function of discharge at the LCR gaging station. Data used in this rating curve were 138 suspended-sand measurements made at this gaging station between 1997 and 2001 (fig. 19). Uncertainties used for the estimates of the sand supplied by the LCR were $30 \%$. No estimates of the silt and clay load of the LCR were made because of the much greater uncertainty associated with computing silt and clay loads by a ratingcurve approach. Thus, no silt and clay budget could be constructed for upper Grand Canyon.

\section{Sand Export from Upper Grand Canyon}

Sand export from upper Grand Canyon during Periods 1 through 5 was computed by multiplying the measured suspended-sand concentrations at the Grand Canyon gaging station by the discharge of water. Uncertainties were $10 \%$ because of the greater number of sedimenttransport measurements at this gaging station.

\section{Mass-Balance Sediment Budgets for Periods 1 through 5}

Sediment budgets for the first five periods of the LSSF experiment are consistent with hypotheses concerning sediment transport described at the beginning of this report (figs. 20 and 21, table 5). The mass balance for sand was negative in Marble Canyon in Periods 1, 2, 3, and 5 and was positive in Period 4. The mass balance for sand in upper Grand Canyon was indeterminate in Periods 1, 2, 3, and 5 and was positive in Period 4. Thus, influxes of tributary fine sediment did not remain in Marble Canyon during Period 1 but were typically more than $250 \mathrm{~m}^{3} / \mathrm{s}\left(8,800 \mathrm{ft}^{3} / \mathrm{s}\right)$. Instead, they were transported past the Lower Marble Canyon gaging station within a few months after tributary inflows. Accumulation only took place during Period 4 when discharges were less than about $250 \mathrm{~m}^{3} / \mathrm{s}\left(8,800 \mathrm{ft}^{3} / \mathrm{s}\right)$. However, because tributary-derived influxes of fine sediment were much lower than average during summer 2000, less sand accumulated during Period 4 than was eroded during the May HMF (Period 2) and the transitional moderate dam releases of Period 3. Thus, less fine sediment was available for entrainment in Marble Canyon at the start of the September HMF than at the start of the May HMF.

\section{Characteristics and Changes in Bed-Sediment Area and Grain Size}

\section{Side-scan Sonar Mapping of Changes in Bed Texture}

Using the methods described in Anima and others (1998) and Wong and others (2003), areas of similar bed texture were identified and classified by R.J. Anima in the side-scan sonar data collected in the three Marble Canyon reaches before and after the September HMF. Four bedtexture classes were identified: sand, finer gravel (i.e., pebbles and cobbles), boulders (i.e., coarser gravel), and bedrock. The sand and finer-gravel classes were further subdivided based on whether they occurred in main-channel or eddy environments (table 6). Near-equivalent areas of interpretable side-scan sonar data were collected during the pre- and post-HMF trips in the Lees Ferry and Redwall Gorge reaches. The area of interpretable side-scan sonar data collected during the post-HMF trip in the Point Hansbrough reach was only approximately $58 \%$ of the area in which interpretable side-scan sonar data were collected in this reach during the pre-HMF trip.

The September HMF caused the area of sand covering the bed to increase and the area of fine gravel to decrease, based on comparison of the side-scan sonar data in the three reaches in Marble Canyon (fig. 22). The area of the bed composed of boulders and bedrock did not significantly change during this period. These findings are similar to those of Anima and others 
(1998), who showed that during the 1996 controlled flood the area of sand on the bed increased despite the fact that the volume of sand on the bed and in the lower elevation parts of eddy sandbars decreased (Andrews and others, 1999; Hazel and others, 1999; Schmidt, 1999). Because the discharge during Period 5 was not high enough to entrain boulders, the small differences in the area of bed composed of boulders and bedrock illustrates of the error associated with interpretation of side-scan sonar data and incorporation into a GIS.

\section{Direct Measurements of Bed-Sediment Grain Size}

The mean grain size of the fine sediment on the surface of the bed coarsened as a result of the September HMF (Period 5), and 12 of the 15 sample sites coarsened. The fine sediment on the bed coarsened by an average of $0.16 \mathrm{~mm}$ in the upstream $93 \mathrm{~km}$ of the study area. The greatest increase in mean grain size was $1.02 \mathrm{~mm}$ at river mile 1.75 , although this value is anomalous relative to the average for the 12 sites that coarsened. Mean grain size decreased at only two sites as a result of the September HMF. These sites are located at river miles 65 and 68, where mean grain size decreased by $0.15 \mathrm{~mm}$ and $0.04 \mathrm{~mm}$, respectively. One site out of 15 , located at river mile 59.95, experienced no change in grain size. Among the four sites downstream from river mile 60, sediment became coarser at two sites and became finer at two sites.

\section{Evaluation of Relative Bed Sediment Coarseness $(\beta)$ to Describe Average System Behavior}

Temporal trends in the grain size of the sand component of the bed largely tracked trends in the sand budget (fig. 23). Bed-grain size was computed using the method of Rubin and Topping (2001). The sand component on the bed abruptly fined following upstream tributary floods during August-September 1999 and then subsequently coarsened until early April 2000, when the sand component of the bed sediment was extremely coarse. Day-to-day variability of $\beta$ values was relatively small compared to monthly trends.

\section{Changes in the Topography of Fine Sediment Deposits on the Bed and along the Channel Margins}

The source of the difference between tributary influx of fine sediment and transport past the Grand Canyon gaging station is the fine sediment that is either evacuated or accumulated on the bed, in sandbars, and in channel-margin deposits. Although the sediment budgets described in the previous section demonstrate that there was some degree of sand evacuation from Marble Canyon during Periods $1,2,3$, and 5, this pattern of channel change is not necessarily reflected in the changes in eddy sandbars or distribution of fine sediment on the bed in every short reach. Similarly, accumulation of sand in Marble Canyon and upper Grand Canyon during Period 4 does not guarantee that accumulation occurred in every short reach, nor do those budgets demonstrate the elevation zone where accumulation occurred. Thus, we made field measurements of changes in fine sediment deposits and analyzed changes on aerial photographs to compare large-scale changes in $\Delta S$ predicted by (1) with patterns of change measured in short reaches or at specific sites.

We measured changes in fine-sediment deposits in two ways: precise measurement of topographic change in a few places and imprecise measurement of change in many places. The precise measurements were made by ground and bathymetric survey and the imprecise measurements were made by mapping the area of every fine-sediment deposit in four study reaches. Each approach has its limitations. Neither approach is a rigorously developed sampling 
scheme, and neither approach is a comprehensive census of the change of every fine-sediment deposit in the study area.

\section{Changes in Fine-Sediment Storage as Measured by Ground Surveys}

Despite a large degree of variability in topographic change from site to site, the average responses of eddy sandbars indicates that fine sediment was redistributed from the bed and lowelevation parts of eddies to the mid-elevation zone during the HMFs. These were the same periods when $\Delta \mathrm{S}$ in Marble Canyon was negative. In contrast, sand was redistributed from the midelevation zone to lower elevations during the low steady flows of Period 4 when $\Delta S$ was positive in Marble Canyon and upper Grand Canyon.

The average response of the mid-elevation zone to the May and September HMFs was an increase in the mean volume of fine sediment. Between March and June, the average volume of fine sediment in the mid-elevation zone increased from 787 to $924 \mathrm{~m}^{3}$ in upper Marble Canyon and increased from 2,370 to 2,697 $\mathrm{m}^{3}$ in lower Marble Canyon (table 7). Although the measurement interval was large and does not uniquely isolate the effect of the May HMF, measurements at river mile 30.7 (described below) and field observations indicate that most of the deposition in the midelevation zones occurred during Period 2. The proportional increase in fine sediment in the midelevation zone was significant in relation to the volume of these deposits measured in March 2000. Deposition between March and June resulted in a 47\% and 51\% increase in the volume of fine sediment in the mid-elevation zone in upper and lower Marble Canyons, respectively (table 8). Deposition in the mid-elevation zone also occurred between August and September, the period spanning the September HMF. The average change in volume in this zone was $+409 \mathrm{~m}^{3}$ and +859 $\mathrm{m}^{3}$ in upper and lower Marble Canyons, respectively (table 7).

In contrast to mid-elevation zone changes, the low-elevation zone was depleted of fine sediment during the HMFs in upper Marble Canyon, where the average volume of fine sediment at low-elevation decreased by $20 \%$ (table 8), from 13,628 to $6,701 \mathrm{~m}^{3}$ (table 7). There were too few measurement sites from which to calculate average change in lower Marble Canyon or upper Grand Canyon between March and June at low elevation. Measurements were only made at two sites in lower Marble Canyon, where one site increased in volume (river mile 47) while the other decreased (river mile 51), and at one site in upper Grand Canyon (river mile 62), where aggradation occurred.

Fine sediment at low elevation was also evacuated during the September HMF. Measurements suggest that this pattern may have occurred in lower Marble Canyon, as well as upper Marble Canyon, because the two sites in lower Marble Canyon lost fine sediment as well as the four measured sites in upper Marble Canyon.

Mid-elevation fine sediment deposits were typically eroded during the low flows of Period 4, when the average volume decreased from 924 to $698 \mathrm{~m}^{3}$ in upper Marble Canyon and from 2,697 to $2,315 \mathrm{~m}^{3}$ in lower Marble Canyon. Some of this fine sediment was presumably transferred to the low-elevation zone because the average volume of sand in this zone increased by $+7,346 \mathrm{~m}^{3}$ in upper Marble Canyon and by $1,270 \mathrm{~m}^{3}$ in lower Marble Canyon (table 7).

The average changes disguise significant site-to-site variability (fig. 24). Substantial aggradation occurred in the mid-elevation zone during both the May and September HMFs at some sites, such as at river miles 30, 51, 55, and 65 (tables 7 and 8). Elsewhere, however, the volume of fine sediment in this zone decreased during the May HMF, such as at river miles 3, 45, and 68, and during the September HMF at river miles 50 and 87.

Topographic changes of the main channel bed and low-elevation zones of eddies reflected a high degree of site-to-site variability. Some sites that aggraded during Periods 2 and 3 eroded 
during the low steady flows of Period 4, such as at river miles 30, 51, and 62 (table 7). In contrast, other sites experienced fine-sediment evacuation during Periods 2 and 3 and aggraded during Period 4, such as at river miles 22, 32, and 35. One site, at river mile 47, aggraded during Periods 2 , 3 , and 4 , but was eroded during Period 5.

Changes in the area and volume of fine sediment in the high-elevation zone at the 19 study sites were insignificant because this zone was not inundated by the HMFs. Surveys conducted since 1990 indicate that the volume of fine sediment in the high-elevation zone significantly increased only during the 1996 controlled flood and slowly and steadily decreased thereafter (fig. 25). This pattern continued during the LSSF when redistribution of sand was caused by wind.

The effects of the overall LSSF experiment were not significantly different among upper Marble Canyon, lower Marble Canyon, and upper Grand Canyon (tables 7 and 8). Therefore, the ground surveys at the 19 study sites provided no evidence of longitudinal differences in eddy sandbar response or the relative proportion of fine sediment transferred among the bed, eddy sandbars, or channel-margin deposits amongst any of the periods of the LSSF.

\section{Changes in Fine-Sediment Storage as Measured by Aerial Photograph Analysis}

Analysis of aerial photographs provides an opportunity to independently evaluate whether the average changes calculated from the precise ground survey measurements were representative of changes averaged for longer reaches. Although Hazel and others (1999) demonstrated that the area of new deposits created by the 1996 controlled flood decreased despite measured increases in volume, the average change in area of mid-elevation fine sediment deposits was similar to the average changes in volume during both HMFs in upper and lower Marble Canyon and in upper Grand Canyon (tables 7 and 8). Thus, we assumed that measured increases in the area of midelevation sand interpreted from aerial photographs indicated that the same area had increased in volume.

The measurements made from aerial photographs for the September HMF indicate that the average trends calculated from the detailed measurement sites were representative of average system response (fig. 26). The average of the three reaches in Marble Canyon indicated that an increase in sandbar area had occurred, which is the same trend as indicated by measurements of area and volume in upper and lower Marble Canyon from ground surveys. Nevertheless, significant variability also exists at the reach scale. For example, the average and median area of eddy sandbars in the mid-elevation zone decreased slightly in the Lees Ferry and Point Hansborough reaches but increased in the Redwall Gorge and Tapeats Gorge (figs. 27 and 28).

Site-to-site variability is even larger than the reach-scale variability, as indicated by the differences in the area of fine sediment at mid-elevation among eddies in a reach (fig. 29), the proportion of each eddy filled with those deposits (fig. 30), the number of eddies that were significantly aggraded or eroded (fig. 31), and the different distributions of net normalized aggradation (NNA) (fig. 32) in each reach caused by the September HMF. The NNA metrics for the September 2000 HMF indicate that the Lees Ferry reach experienced more erosion, relative to the amount of deposition, than any other reach (fig. 32).

\section{Amount of Reworking in Eddy Sandbars as Determined by Scour Chain Recovery}

Surveys of scour chains before and after the September 2000 HMF show that statistics describing net change of eddy sandbar topography disguise the magnitude of scour and fill that took place at different times and in different parts of the same eddy. Based on all recoverable scour chains, both offshore and nearshore sites within about $20 \mathrm{~m}$ of the shoreline experienced only 
deposition (fig. 33). However, a few scour chains ranging from 18 to $87 \mathrm{~m}$ from the shoreline at $878 \mathrm{~m}^{3} / \mathrm{s}\left(31,000 \mathrm{ft}^{3} / \mathrm{s}\right)$ were not recovered, thus indicating that some sites experienced more than 1 $\mathrm{m}$ of scour (table 4). For example, one chain at the Carbon Creek fan-eddy complex (river mile 65) was not recovered, yet freshly deposited sand was observed at the site and net deposition of $80 \mathrm{~cm}$ was measured by ground surveys. Therefore, this site experienced at least $1 \mathrm{~m}$ of scour followed by at least $1.8 \mathrm{~m}$ of fill.

\section{Changes in Fine-Sediment Storage as Measured by Ground Surveys: Daily Changes at One Study Site}

Measurements of topographic change of the eddy sandbar at river mile 30.7 during the September HMF further illustrate the dynamic processes of scour and fill that caused the topographic changes described above. Although the details of these processes undoubtedly differ from site to site, they further illustrate that net topographic change may result from deep scour or thick fill in some parts of eddies. Initially, the eddy sandbar at river mile 30.7 was rapidly eroded. Subsequently, there was gradual deposition, punctuated by a smaller erosion event between the first and second days of the HMF. Erosion of 7,630 $\mathrm{m}^{3}$ of sand occurred on the rising limb of the HMF on September 5 (table 9). As a result, a semicircular depression more than $3 \mathrm{~m}$ deep was formed in the middle to upstream portion of the reattachment sandbar (fig. 34). This erosion event and the resulting semicircular depression probably was the result of a subaqueous mass failure. This mass failure of the sandbar occurred solely beneath the water surface, and the high-elevation portion of the sandbar was not affected. At least some of this eroded material was not immediately transported downstream and temporarily filled part of the main channel, where more than $2 \mathrm{~m}$ of fine sediment accumulated. The next survey was performed $3 \mathrm{~h}$ later when this 2-m-thick deposit on the bed had been scoured. On September 6, an additional 4,340 $\mathrm{m}^{3}$ of sand was eroded from the eddy. This erosion occurred upstream from the area of slumping the day before. Deposition of fine sediment during the following $2 \mathrm{~d}$ replaced about half of the sand scoured from the eddy. This deposition was greatest on the upstream part of the reattachment sandbar near the reattachment point and in the upstream depression resulting from the failure on September 5. Much of the eddy sandbar platform in this area was gradually covered with $1-2 \mathrm{~m}$ of sand.

The overall response at this eddy sandbar to the September HMF varied among the different elevation zones. Deposition of $580 \mathrm{~m}^{3}$ of fine sediment in the mid-elevation zone resulted in a $40 \%$ increase in fine-sediment volume and a $16 \%$ increase in fine-sediment area (table 8). However, $3,060 \mathrm{~m}^{3}$ of fine sediment was scoured from the low-elevation zone in the eddy, constituting a $23 \%$ volume decrease. The net effect of the September HMF was a loss of 2,520 $\mathrm{m}^{3}$ of fine sediment from the eddy (table 9). The main channel experienced a net volume increase of $1,135 \mathrm{~m}^{3}$ of fine sediment, or a $16.6 \%$ increase, because of additional slumping of fine sediment from the eddy (table 8).

Rapid failure of eddy sandbars has been documented during normal dam operations (Cluer, 1995), during the 1996 controlled flood (Andrews and others, 1999; Konieczki, and others, 1997), and during the 2-d 1997 test flow of $878 \mathrm{~m}^{3} / \mathrm{s}$ (Hazel and others, 2000); although, this process may not be common. Andrews and others (1999) suggested rapid erosion resulted from high deposition rates and mass failure of over-steepened, unconsolidated sandbar slopes, and models suggest that sandbar failure is not a result of declining sand concentration (Wiele and others, 1999). Further study is needed to resolve the processes involved in eddy sandbar response to changes in dam operations. When mass failures occur during the onset of high flows, the aggradation that follows may not replace the sand that was initially eroded from eddy sandbars (Schmidt, 1999). 


\section{Characteristics of Eddy Sandbars during the LSSF in Relation to Characteristics Observed since 1984}

The increases in the mean and median area of eddy sandbars in the mid-elevation zone caused by the September 2000 HMF were small in the context of the longer term record since 1984. Increases in sandbar area at mid-elevation did not return sandbars to the size they had been in 1984 . In some cases, sandbars were not restored to the sizes they had been in 1990.

The longer history of sandbar change reflects progressive loss of fine sediment since 1984. The total area of fine-sediment deposits in the mid-elevation zone in all study reaches decreased significantly from 1984 to 1990 (fig. 27A). Thereafter, the study reaches have responded in somewhat different ways. In the Redwall Gorge, Point Hansbrough, and Tapeats Gorge reaches there was no significant difference in eddy sandbar area in the mid-elevation zone between 1990 and 2000. Between April 1996 and August 2000, mean eddy sandbar area and total fine-sediment area in the mid-elevation zone increased in all reaches to conditions similar to those in 1990 (Figs. $26,28)$. In the Redwall Gorge reach, the area of mid-elevation fine-sediment increased substantially soon after the 1996 controlled flood and then decreased by August 2000, with changes during this period being more pronounced in eddy sandbars than in channel-margin deposits (fig. 27C). This trend is similar to that determined by averaging change measured at the 19 study sites (fig. 26). All reaches exhibited their lowest mean and median eddy sandbar sizes in the mid-elevation zone in April 1996. The volume of fine sediment in the mid-elevation zone was typically less in 2000 than in 1996, although the volume of sand at a few sites was nearly as large as those measured at other times in the 1990s (fig. 24).

The 1984-2000 time series of sandbar area shows that the Lees Ferry reach has experienced erosion of greater magnitude and persistence than the other reaches. Between 1990 and 1996, the total area of fine sediment in the Lees Ferry reach continued to decline. The loss of fine-sediment area in this reach between 1990 and 2000 was greatest in channel-margin deposits (fig. 27B). The greatest decrease in total fine-sediment area occurred between March and April 1996, when the 1996 controlled flood redistributed fine sediment to the high-elevation zone (Schmidt and others, 2004). By August 2000, the area of fine sediment in the Lees Ferry reach remained significantly less than in 1990, while the total fine-sediment area in the three downstream reaches was not significantly different from the 1990 area.

Eddy sandbars at mid-elevation filled less of the eddy deposition zone in April 1996 than at any other time, and increased between April 1996 and August 2000 (figs. 28 and 30). Only the Redwall Gorge reach showed an increase in fill ratio because of the September 2000 HMF (fig. 28). By September, the fill ratios in the Redwall Gorge and Point Hansbrough reaches were near 1984 levels; although, both the cumulative and site-specific fill ratios of the Lees Ferry and Tapeats Gorge reaches had significantly decreased.

Different flow regimes since 1984 have caused sandbar area and fill ratios to be more or less similar to each other, as reflected in the magnitude of the inter-quartile range (fig. 29). Eddy sandbars within each reach were more similar to each other immediately following the 1996 controlled flood than at any other time. The variability of eddy sandbar area increased after the 1996 controlled flood in all reaches except Lees Ferry.

The reach-to-reach variability in sandbar response to flow regime change is further illustrated by different distributions of the number of eddies where significant erosion or deposition occurred in each reach. In addition, similar flow regime changes caused different proportional changes in the study area. The 1996 controlled flood and September $2000 \mathrm{HMF}$ caused different styles of change in eddy sandbar area. The larger 1996 controlled flood caused decreases in the area 
of mid-elevation sand in all reaches, but increases in sandbar area in this elevation zone occurred in September 2000 in the Redwall Gorge.

\section{Changes in Backwater Area}

The total area of backwater (i.e., eddy return-current channel) habitat increased in all reaches during the September HMF except in the Redwall Gorge reach, where backwater area decreased slightly (fig. 35). The number of backwaters also increased significantly in the Tapeats Gorge and Redwall Gorge reaches. The number and total area of backwaters within each reach in September 2000 were comparable to those in 1984, when these study reaches contained more and larger backwaters than at any other time during the period of record examined by Goeking and others (2003). Therefore, backwater area has not been greatly affected by the long-term declines in eddy sandbar area in Marble and Grand Canyons.

\section{Discussion and Conclusions}

The LSSF experiment can be evaluated in two ways: as a demonstration project and as opportunity to refine scientific understanding. As a demonstration project, one goal of the LSSF was to restrict the downstream transport of fine sediment by decreasing dam releases in the summer when tributary resupply of fine sediment was anticipated. Another purpose of the LSSF was to redistribute the tributary-supplied fine sediment to channel-margin deposits and eddy sandbars during the September HMF. This demonstration project was of limited success because tributary inflows were unusually low in summer 2000. The May and September HMFs did significantly increase the volume and area of fine sediment in eddy sandbars in the mid-elevation zone, but the magnitude of the increase was small relative to other observed increases in deposit volume and area since 1984. The two HMFs did not reverse the long-term trend of decreasing eddy sandbar volume in Marble and upper Grand Canyons.

In terms of improving scientific understanding, the LSSF was generally successful in the sense that integrated measurements were made of main-channel and eddy processes. Measurements of main-channel fine-sediment storage, eddy fine-sediment storage, and associated sediment budgets show that fine sediment was exported from Marble Canyon when dam releases were greater than approximately $250 \mathrm{~m}^{3} / \mathrm{s}\left(8,800 \mathrm{ft}^{3} / \mathrm{s}\right)$, and that fine sediment accumulated in Marble Canyon when dam releases were less than $250 \mathrm{~m}^{3} / \mathrm{s}$. These results demonstrate that tributarysupplied fine sediment is exported from Marble Canyon during all but the lowest dam releases, and that interannual accumulation is likely to occur only if discharge is restricted to less than approximately $250 \mathrm{~m}^{3} / \mathrm{s}$. Values of $\beta$ reflect these trends and also indicate that the bed sand was coarsest and the sand supply was the most depleted in Marble and upper Grand Canyons in June 2000 than compared to any previous time. Thus, it was not surprising that the volume or area of eddy sandbars changed little during the September HMF.

Comparison of the sand mass balance with measured changes in components of $\Delta S$ demonstrate that sand is stored in and is transferred among different elevation zones by different flow regimes (table 10). Sand accumulated in the mid-elevation zone during the two HMFs, and sand was eroded from the low-elevation zone by the same flows. In contrast, sand was eroded from the mid-elevation zone and accumulated in the low elevation zone during Period 4. Thus, changes in sand volume at low elevation in eddies mirror changes in the large-scale, sand mass balance. In contrast, changes in the area of sand on the bed increased during periods when evacuation of sand occurred. 
At smaller spatial scales, reach and site-scale differences appear to determine if net evacuation or accumulation of sand occurs in eddies. Thus, reach average or larger scale metrics disguise the fact that there are always eddies that lose sand when most nearby eddies gain sand, and vice versa. In fact, during Period 5 when the mid-elevation zone was accumulating sand in most areas, eddy sandbars near Lees Ferry and Point Hansborough typically lost sand. Thus, the inherent characteristics of site-to-site variability in eddy sandbar response to changing flows and sediment supply must be considered in development of robust metrics that describe systemwide change in key sediment-related resources, such as the area of campsites.

The effects of the May and September HMFs differed with respect to the fine-sediment supply and the consequent effects on fine-sediment storage in eddy sandbar and channel-margin deposits. Because of the small amount of fine sediment supplied by tributaries between the May and September HMFs, less fine sediment was available for transport and deposition during the September HMF than during the May HMF. The difference in upstream fine-sediment supply between the two HMFs was most pronounced during the first day of high discharge, whereas the fine-sediment supply was similar between the two HMFs after the first day. Thus, the recent influxes of tributary fine sediment were exhausted quickly during the rising limb and first day of the September HMF. Following this initial period, the predominant source of the fine sediment exported from Marble Canyon during the September HMF was the eddy sandbars, as was the case during the 1996 controlled flood (Schmidt, 1999; Hazel and others, 2006). Measurements of eddy sandbar scour and fill corroborate this pattern. For example, detailed surveys at an eddy sandbar at river mile 30.7 documented rapid erosion followed by gradual deposition of fine sediment during the September HMF, but an overall net loss of fine sediment. Similarly, scour-chain data from the mid-elevation zone indicated that most eddies experienced erosion followed by deposition, and low-elevation parts of eddy sandbars experienced net erosion during the September HMF. This result is expanded upon in Hazel and others (2006).

Samples of suspended and bed sediment illustrated a downstream increase in sediment transport throughout the duration of the LSSF experiment. The concentration of suspended sediment increased and the grain size of the suspended sediment decreased over the upstream 161 $\mathrm{km}$ on all three sampling trips (May, July, and September). The increase in suspended-sand concentration was most pronounced downstream from the Paria River and was more gradual throughout the rest of Marble and upper Grand Canyons. Similarly, the increase in suspended-silt and clay concentration was most pronounced downstream from the LCR. No new tributary finesediment input occurred during the suspended-sediment sampling trips, so the increasing concentration reflected the progressive erosion of stored fine sediment from the bed of the main channel and eddies, even during the low steady flows in July. Suspended-sediment data show that most of the fine sediment eroded during the September HMF was eroded from upper Marble Canyon. These changes in suspended sediment resulted from a downriver increase in the amount of suspended sediment in the eddies and main channel and a downriver decrease in the grain size of the fine sediment on the bed, thus causing the median grain size of suspended sediment to decrease and the concentration of suspended sediment to increase. Grain size of the surficial bed sediment also coarsened during the September HMF, especially in the upstream $93 \mathrm{~km}$ nearest Lees Ferry.

Reach-scale maps of the distribution of fine sediment support the conclusion that downstream increases in suspended-sand concentrations represent the erosion of sand stored in channel-margin and eddy sandbar deposits. While none of the reaches experienced significant changes in fine-sediment area because of the LSSF experiment, net normalized aggradation values were negative only in the Lees Ferry reach, indicating that this reach experienced more erosion than 
deposition. The Lees Ferry reach contained significantly less fine sediment in 2000 than in 1990; in contrast, this trend did not occur in the three downstream reaches. Only in the Lees Ferry reach has a substantial decline in the area of mid-elevation fine sediment in eddies continued through 2000 , indicating that fine sediment from this reach continues to be exported downstream.

\section{References}

Andrews, E.D., Johnson, C.E., Schmidt, J.C., and Gonzales M., 1999, Topographic evolution of sand bars, in Webb, R.H., Schmidt, J.C., Marzolf, G.R., and Valdez, R.A., eds., The controlled flood in Grand Canyon: Washington, D.C., American Geophysical Union, Geophysical Monograph Series, v. 110, p. 117-130.

Anima, R.J., Marlow, M.S., Rubin, D.M., and Hogg, D.J., 1998, Comparison of sand distribution between April 1994 and June 1996 along six reaches of the Colorado River in Grand Canyon, Arizona: U.S. Geological Survey Open-File Report 98-141, 33 p.

Beus, S.S., and Avery, C.C., 1992, The influence of variable discharge regimes on Colorado River sand bars below Glen Canyon Dam: Flagstaff, Ariz., Northern Arizona University, Final report to Glen Canyon Environmental Studies, 451p., [http://www.gcmrc.gov/library/reports/physical/Fine_Sed/beus1993.pdf].

Bureau of Reclamation, 2000, Reclamation will test low steady flow releases from Glen Canyon Dam this coming summer: Salt Lake City, Press release, 2 p.

Chezar, H., 2001, Underwater microscope system: U.S. Geological Survey Fact Sheet 135-01.

Cluer, B. L., 1995, Cyclic fluvial processes and bias in environmental monitoring, Colorado River in Grand Canyon: Journal of Geology, v. 103, p. 411-421.

Edwards, T.K., and Glysson, G.D., 1988, Field methods for measurement of fluvial sediment: U.S. Geologic Survey Open-File Report 86-531, 118 p

Fritzinger, C., Liszewski, M., Melis, T.S., Mietz, S., Ralston, B., Yard, M., and Gold, B.D., 2000, A science plan for WY2000 low summer steady flows: Flagstaff, Ariz., Grand Canyon Monitoring and Research Center, 74 p., [http://www.gcmrc.gov/library/reports/synthesis/LSSF2000.pdf].

Goeking, S.A., Webb, M.K., and Schmidt, J.C., 2003, Spatial and temporal trends in the area and number of backwaters between 1935 and 2000, Marble and Grand Canyons, Arizona: final draft report to the Grand Canyon Monitoring and Research Center, cooperative agreement no. 01WRAG0059, 26 p., [http://www.gcmrc.gov/library/reports/physical/hydrology/Goeking2004.pdf].

Grams, P.E., and Schmidt, J.C., 1999, Integration of photographic and topographic data to develop temporally and spatially rich records of sand bar change in the Point Hansbrough and Little Colorado River confluence study reaches: Logan, Utah, Utah State University, Final report to the Grand Canyon Monitoring and Research Center, 249 p., [http://www.gcmrc.gov/library/reports/physical/Fine_Sed/Grams1999b.pdf].

Grams, P. E., Schmidt, J. C., and Topping, D. J., 2007, The rate and pattern of bed incision and bank adjustment on the Colorado River in Glen Canyon downstream from Glen Canyon Dam, 1956-2000: Geological Society of America Bulletin, v. 119, no. 5, p. 556-575. 
Hazel, J.E., Kaplinski, M., Parnell, R., Manone, M., and Dale, A., 1999, Topographic and bathymetric changes at thirty-three long-term study sites, in Webb, R.H., Schmidt, J.C., Valdez, R.A., and Marzolf, G.R., eds., The Controlled Flood in Grand Canyon: Geophysical Monograph Series, v. 110, American Geophysical Union, p. 161-183.

Hazel, J.E. Jr., Kaplinski, M., Parnell, R., and Manone, M., 2000, Sand deposition in the Colorado River ecosystem from flooding of the Paria River and the effects of the November 1997, Glen Canyon Dam Test Flow: Final report to the Grand Canyon Monitoring and Research Center, Northern Arizona University, Flagstaff, Ariz., 37 p., [http://www.gcmrc.gov/library/reports/physical/Fine_Sed/Hazel2000b.pdf].

Hazel, J., Jr., Topping, D.J., Schmidt, J.C., and Kaplinski, M., 2006, Influence of a dam on finesediment storage in a canyon river: Journal of Geophysical Research, v. 111, F01025, 16 p.

Howard, A. and Dolan, R., 1981, Geomorphology of the Colorado River in the Grand Canyon: Journal of Geology, v. 89, p. 269-298.

Kaplinski, M., Hazel, J.E., and Beus, S.S., 1995, Monitoring the effects of interim flows from Glen Canyon Dam on sand bars in the Colorado River corridor, Grand Canyon National Park, Arizona: U.S. Bureau of Reclamation, Glen Canyon Environmental Studies.

Kaplinski, M., Hazel, J.E., Parnell, R., Manone, M., and Gonzales, M., 2000, Evaluation of hydrographic survey techniques used for channel mapping by the Grand Canyon Monitoring and Research Center in the Colorado River Ecosystem, Grand Canyon, Arizona: Final report to the Grand Canyon Monitoring and Research Center, Northern Arizona University, Flagstaff, Ariz., 37 p., [http://www.gcmrc.gov/library/reports/physical/Fine_Sed/Parnell2000.pdf].

Kearsley, L.H., Schmidt, J.C., Warren, K.D., 1994, Effects of Glen Canyon Dam on Colorado River sand deposits used as campsites in Grand Canyon National Park, USA: Regulated Rivers: Research and Management, v. 9, p. 137-149.

Kieffer, S.W., 1985, The 1983 hydraulic jump in Crystal Rapid: Implications for river-running and geomorphic evolution in the Grand Canyon: Journal of Geology, v. 93, p. 385-406.

Kieffer, S.W., 1987, The rapids and waves of the Colorado River, Grand Canyon, Arizona: U.S. Geological Survey Open-File Report 87-096, 69 p.

Konieczki, A.D., Graf, J.B., and Carpenter, M.C., 1997, Streamflow and sediment data collected to determine the effects of a controlled flood in March and April 1996 on the Colorado River between Lees Ferry and Diamond Creek, Arizona: U.S. Geological Survey Open-File Report $97-$ $224,55 \mathrm{p}$.

Larsen, I.J., Schmidt, J.C., and Martin, J.A., 2004, Debris fan reworking during low magnitude floods in the Green River canyons of the eastern Uinta Mountains, Colorado and Utah: Geology, v. 32, no. 4, p. 309-312.

McDonald, R.R., Bennett, J.P., and Nelson, J.M., 2001, The USGS multidimensional surface water modeling system: Proceedings of the Seventh Federal Interagency Sedimentation Conference, Reno, Nevada, p. I-161 to I-167.

National Research Council, 1996, River resource management in the Grand Canyon: Washington, D.C., National Academy Press, 226 p. 
Pemberton, E.L., 1976, Channel change in the Colorado River below Glen Canyon Dam, in $3^{\text {rd }}$ Federal Interagency Sedimentation Conference, p. 5-61 to 5-73.

Pizzuto, J.E., Webb. R.H., Griffiths, P.G., Elliott, J.G., and Melis, T.S., 1999, Entrainment and transport of cobbles and boulders from debris fans, in Webb, R.H., Schmidt, J.C., Marzolf, G.R., and Valdez, R.A., eds., The controlled flood in Grand Canyon: Washington, D.C., American Geophysical Union, Geophysical Monograph Series, v. 110, p. 53-70.

Rubin, D.M., 2004, A simple autocorrelation algorithm for determining grain size from digital images of sediment: Journal of Sedimentary Research, v. 74, p. 160-165.

Rubin, D.M., Schmidt, J.C., and Moore, J.N., 1990, Origin, structure, and evolution of a reattachment bar, Colorado River, Grand Canyon, Arizona: Journal of Sedimentary Petrology, v. 60, p. 982-991.

Rubin, D.M., Schmidt, J.C., Anima, R.A., Brown, Kristin, M., Hunter, R.E., Ikeda, H., Jaffe, B.E., McDonald, R., Nelson, J.M., Reiss, T.E., Sanders, R., and Stanley, R.G., 1994, Internal structure of bars in Grand Canyon and evaluation of proposed flow alternatives for Glen Canyon Dam: U.S. Geological Survey Open-File Report 94-594, 56 p.

Rubin, D.M., Nelson, J.M., and Topping, D.J., 1998, Relation of inversely graded deposits to suspended-sediment grain-size evolution during the 1996 flood experiment in Grand Canyon: Geology, v. 26, p. 99-102.

Rubin, D.M., and Topping, D.J., 2001, Quantifying the relative importance of flow regulation and grain-size regulation of suspended-sediment transport $(\alpha)$, and tracking changes in bed-sediment grain size $(\beta)$ : Water Resources Research, v. 37, p. 133-146.

Rubin, D.M., Topping, D.J., and Chezar, H., 2001, In-situ grain-size analysis using digital images collected by underwater microscopy: International Association for Mathematical Geology, Cancun, Mexico.

Rubin, D.M., Topping, D.J., Schmidt, J.C., Hazel, J., Kaplinski, K., and Melis, T.S., 2002, Recent sediment studies refute Glen Canyon Dam hypothesis: EOS, Transactions, American Geophysical Union, v. 83, n. 25, p. 273 and 277-278.

Rubin, D.M., Chezar, H., Harney, J.N., Topping, D.J., Melis, T.S., and Sherwood, C.R., 2006, Underwater microscope for measuring spatial and temporal changes in bed-sediment grain size: U.S. Geological Survey Open-File Report 2006-1360, [http://pubs.usgs.gov/of/2006/1360/].

Rubin, D.M., Chezar, H., Topping, D.J., Melis, D.J., and Harney, J., in press, Two new approaches for measuring spatial and temporal changes in bed-sediment grain size: Sedimentary Geology.

Schmidt, J.C., 1990, Recirculating flow and sedimentation in the Colorado River in Grand Canyon, Arizona: Journal of Geology, v. 98, p. 709-724.

Schmidt, J.C., and Graf, J.B., 1990, Aggradation and degradation of alluvial sand deposits, 1965 to 1986, Colorado River, Grand Canyon National Park, Arizona: U.S. Geological Survey Professional Paper 1493, 74 p.

Schmidt, J.C., and Leschin, M.F., 1995, Geomorphology of post-Glen Canyon Dam fine-grained alluvial deposits of the Colorado River in Point Hansbrough and Little Colorado River confluence study reaches in Grand Canyon National Park, Arizona: Final draft report for the Bureau of Reclamation, Glen Canyon Environmental Studies. 
Schmidt, J. C., and Rubin, D. M., 1995, Regulated streamflow, fine-grained deposits, and effective discharge in canyons with abundant debris fans: Geophysical Monograph, v. 89, p. 177-194.

Schmidt, J.C., 1999, Summary and synthesis of geomorphic studies conducted during the 1996 controlled flood in Grand Canyon, in Webb, R.H., Schmidt, J.C., Marzolf, G.R., and Valdez, R.A., eds., The 1996 controlled flood in Grand Canyon: Washington, D.C., American Geophysical Union, Geophysical Monograph Series, v. 110, p. 329-342.

Schmidt, J.C., Grams, P.E., and Leschin, M.F., 1999, Geomorphology of post-Glen Canyon dam fine-grained alluvial deposits of the Colorado River in the Point Hansbrough and Little Colorado River confluence study reaches in Grand Canyon National Park, Arizona: Bureau of Reclamation, Glen Canyon Environmental Studies.

Schmidt, J.C., Topping, D.J., Grams, P.E., and Hazel, J.E., 2004, System-wide changes in the distribution of fine sediment in the Colorado River corridor between Glen Canyon Dam and Bright Angel Creek, Arizona: Final report to the Grand Canyon Monitoring and Research Center, Flagstaff, Ariz., [http://www.gcmrc.gov/library/reports/physical/Fine_Sed/Schmidt2004.pdf].

Sondossi, H.A., 2001, Historical analysis of the geomorphology of sand bars along the Colorado River in upper Marble Canyon, Arizona: Utah State University, M.S. thesis, 138 p.

Sondossi, H.A., Schmidt, J.C., Goeking, S.A., and Grams, P.E., 2002, Historical change in the geomorphology of sand bars in Redwall Gorge: Final plates to the Grand Canyon Monitoring and Research Center.

Topping, D.J., 1997, Physics of flow, sediment transport, hydraulic geometry, and channel geomorphic adjustment during flash floods in an ephemeral river, the Paria River, Utah and Arizona: University of Washington, unpublished Ph.D. thesis, $406 \mathrm{p}$.

Topping, D.J., Rubin, D.M., Nelson, J.M., Kinzel, P.J., III, and Bennett, J.P., 1999, Linkage between grain-size evolution and sediment depletion during Colorado River floods, in Webb, R.H., Schmidt, J.C., Marzolf, G.R., and Valdez, R.A., eds., The controlled flood in Grand Canyon: Washington, D.C., American Geophysical Union, Geophysical Monograph Series, v. 110, p. 71-98.

Topping, D.J., Rubin, D.M., and Vierra, L.E., Jr., 2000a, Colorado River sediment transport 1. Natural sediment supply limitation and the influence of Glen Canyon Dam: Water Resources Research, v. 36, p. 515-542.

Topping, D.J., Rubin, D.M., Nelson, J.M., Kinzel, III, P.J., and Corson, I.C., 2000b, Colorado River sediment transport 2. Systematic bed-elevation and grain-size effects of sand supply limitation: Water Resources Research, v. 36, p. 543-570.

U.S. Department of the Interior, 1995, Operation of Glen Canyon Dam Final Environmental Impact Statement: Salt Lake City, Utah, Bureau of Reclamation, 337 p.

U.S. Geological Survey, 2006, Grand Canyon Monitoring and Research Center, Colorado River Mileage System [Spatial Database, GIS.BASE_GCMRC_TenthMile], $1^{\text {st }}$ revised edition, http://www.gcmrc.gov/products/ims/ims.htm, accessed June 16, 2006.

Webb, R.H., 1996, Grand Canyon, a century of change: rephotography of the 1889-1890 Stanton expedition: Tucson, Ariz., The University of Arizona Press, 290 p. 
Webb, R.H., Pringle, P.T., Reneau, S.L., and Rink, G.R., 1988, Monument Creek debris flow, 1984, Implications for formation of rapids on the Colorado River in Grand Canyon National Park: Geology, v. 16, p. 50-54.

Webb, R.H., Pringle, P.T., and Rink, G.R., 1989, Debris flows from tributaries of the Colorado River, Grand Canyon National Park, Arizona: U.S. Geological Survey Professional Paper 1492, $39 \mathrm{p}$.

Webb, R.H., Schmidt, J.C., Valdez, R.A., and Marzolf, G.R., 1999, The controlled flood in Grand Canyon: Washington D.C., American Geophysical Union, Geophysical Monograph Series, v.110, $367 \mathrm{p}$.

Wiele, S.M., Andrews, E.D., and Griffin. E.R., 1999, The effect of sand concentration on depositional rate, magnitude, and location in the Colorado River below the Little Colorado River, in Webb, R.H., Schmidt, J.C., Marzolf, G.R., and Valdez, R.A., eds., The controlled flood in Grand Canyon: Washington, D.C., American Geophysical Union, Geophysical Monograph Series, v. 110, p. 131-145.

Wong, F. L., Anima, R. J., Galanis, P., Codianne, J., Xia, Y., Bucciarelli, R., and Hamer, M., 2003, Grand Canyon riverbed sediment changes, experimental release of September 2000; a sample data set: U.S. Geological Survey Open-File Report 03-0265.

Wright, S.A., Melis, T.S., Topping, D.J., and Rubin, D.M., 2005, Influence of Glen Canyon Dam operations on downstream sand resources of the Colorado River in Grand Canyon, in Gloss, S.P., Lovich, J.E., and Melis, T.S., eds., The state of the Colorado River ecosystem in Grand Canyon: U.S. Geological Survey Circular 1282, p. 17-31.

Zilkoski, D.B., D’Onofrio, J.D., Frakes, S.J., 1997, Guidelines for establishing GPS derived ellipsoid heights (standards: $2 \mathrm{~cm}$ and $5 \mathrm{~cm}$ ) version 4.3: Silver Springs, Maryland, National Oceanic and Atmospheric Administration Technical Memorandum NOS NGS-58, [http://www.ngs.noaa.gov/PUBS_LIB/NGS-58.html]. 


\section{Figures}

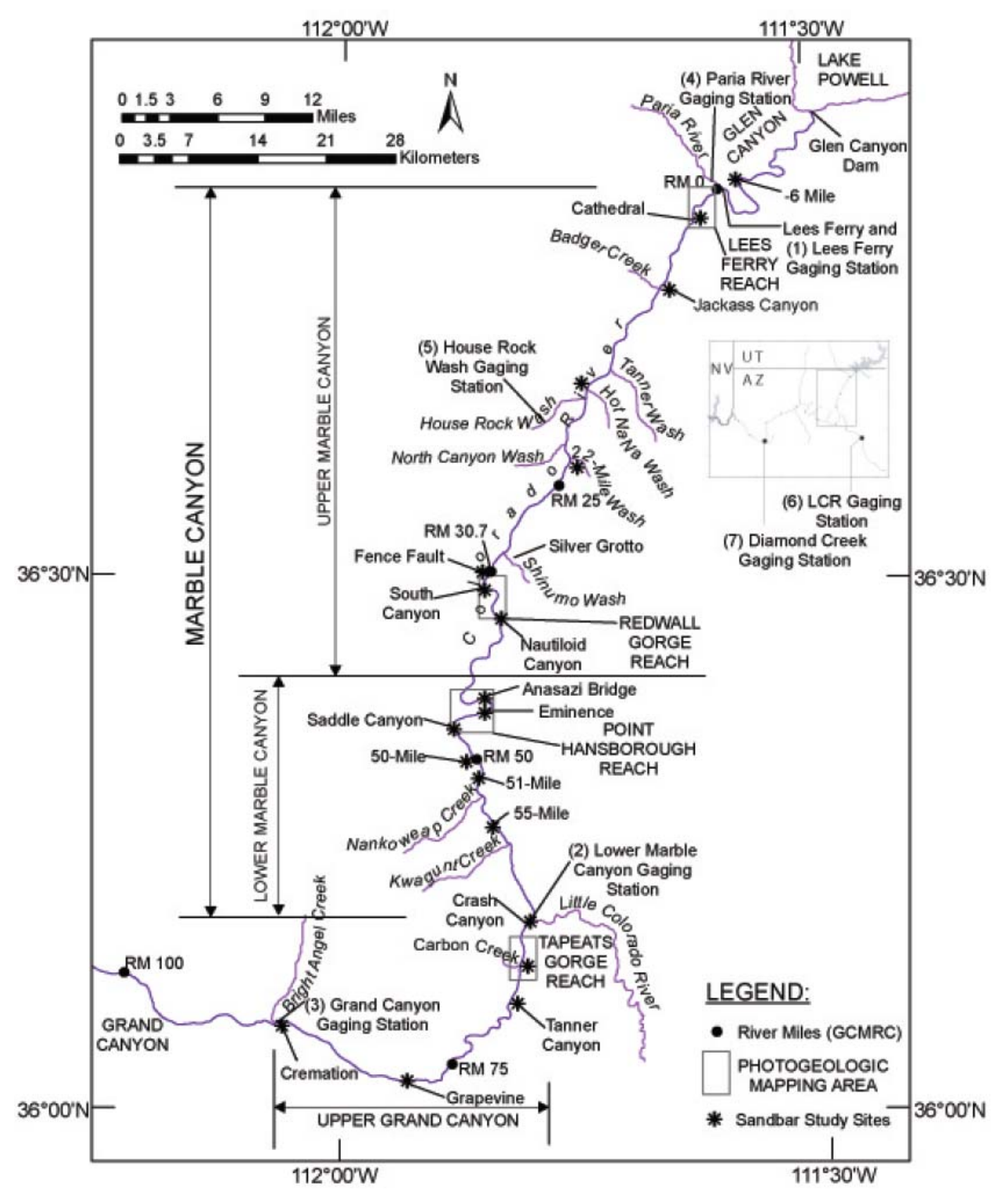

Figure 1. Map showing the Colorado River in Marble and Grand Canyons. U.S. Geological Survey gaging stations are located at (1) Colorado River at Lees Ferry, Ariz., station 09380000, (2) Colorado River above Little Colorado River near Desert View, Ariz., station number 09383100, (3) Colorado River near Grand Canyon, Ariz., station number 09402500, (4) Paria River near Lees Ferry, Ariz., station number 09382000, (5) House Rock Wash, Ariz., (6) Little Colorado River near Cameron, Ariz., station number 09402000, and (7) Colorado River above Diamond Creek near Peach Springs, Ariz., station number 09402400. Each of the 19 fan-eddy complexes surveyed in March, June, August, and September 2000 are indicated with asterisks. Boxes enclosed areas of comprehensive photogeologic mapping. 


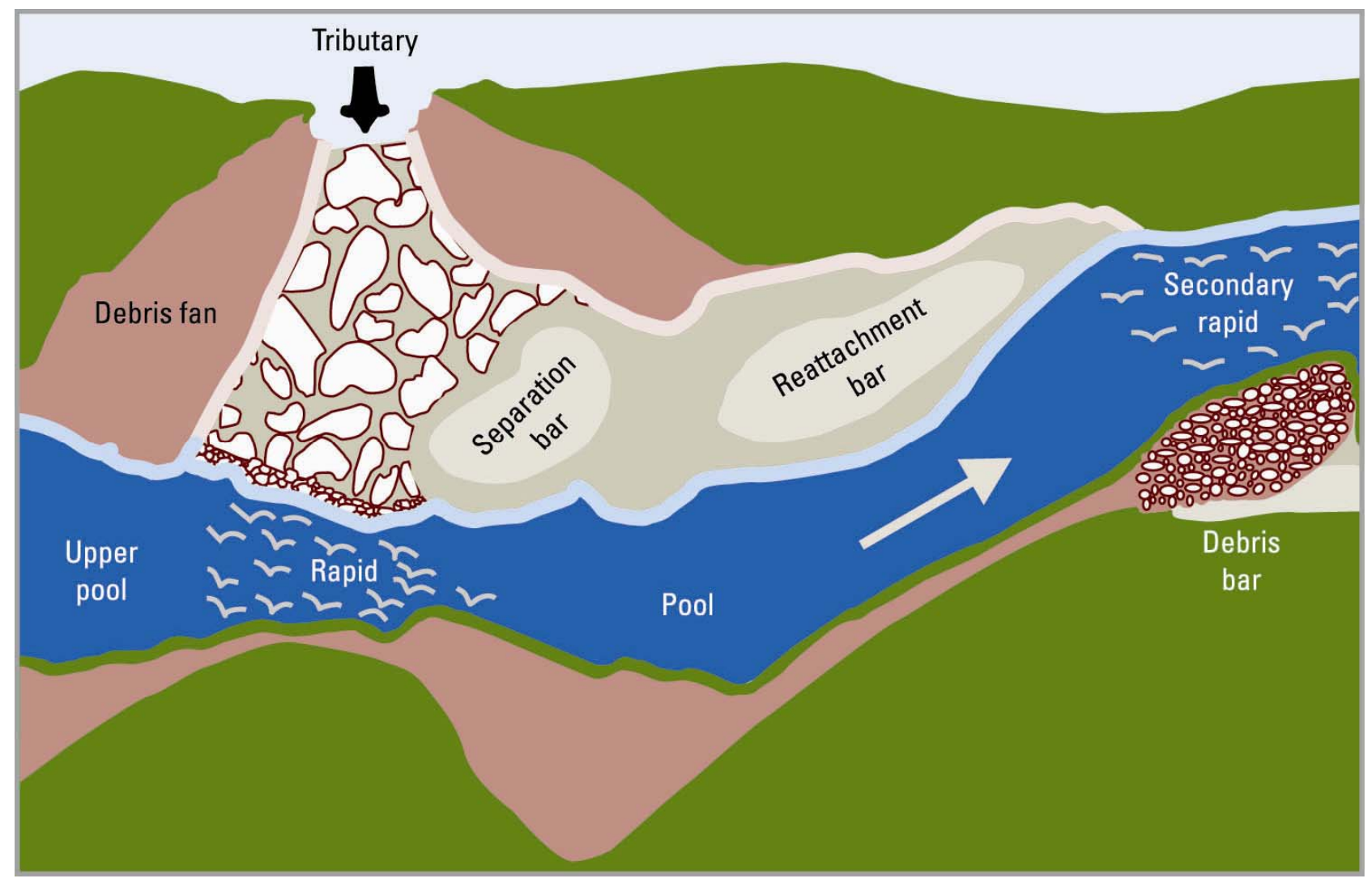

Figure 2. Diagram of a typical fan-eddy complex. 


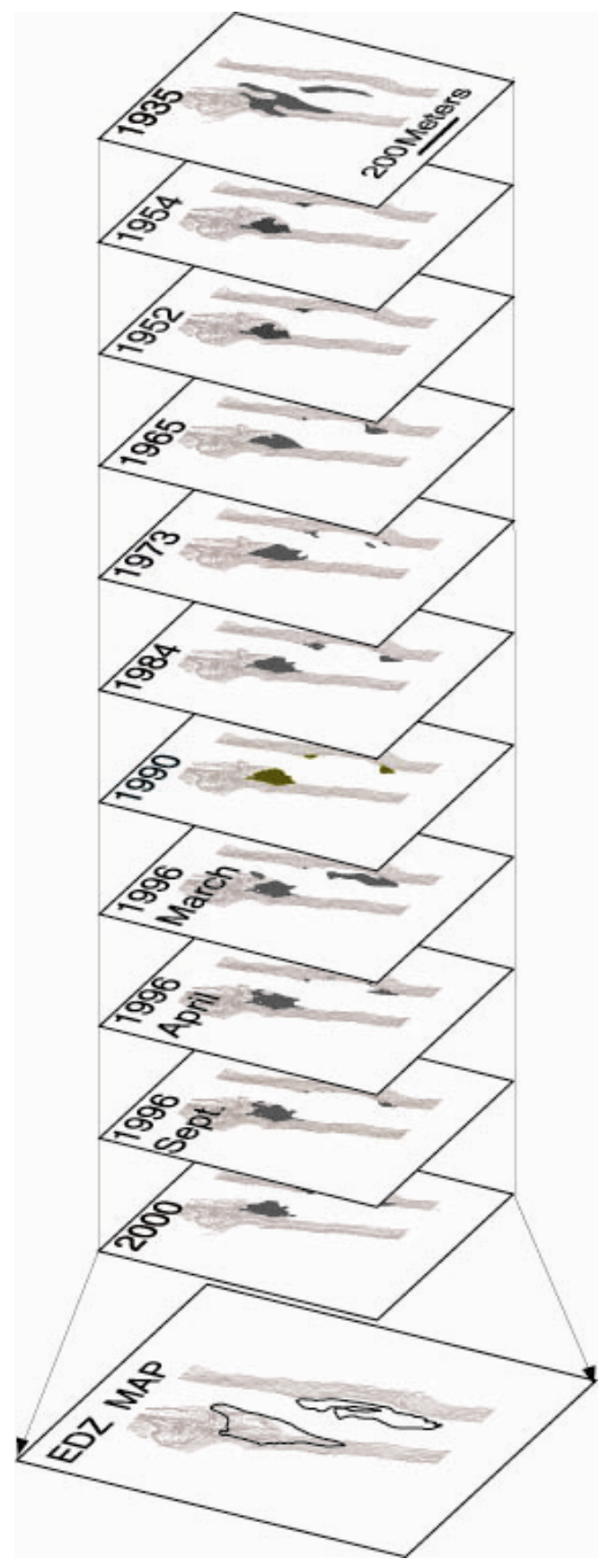

Figure 3. Diagram showing method of calculation of eddy deposition zones. 


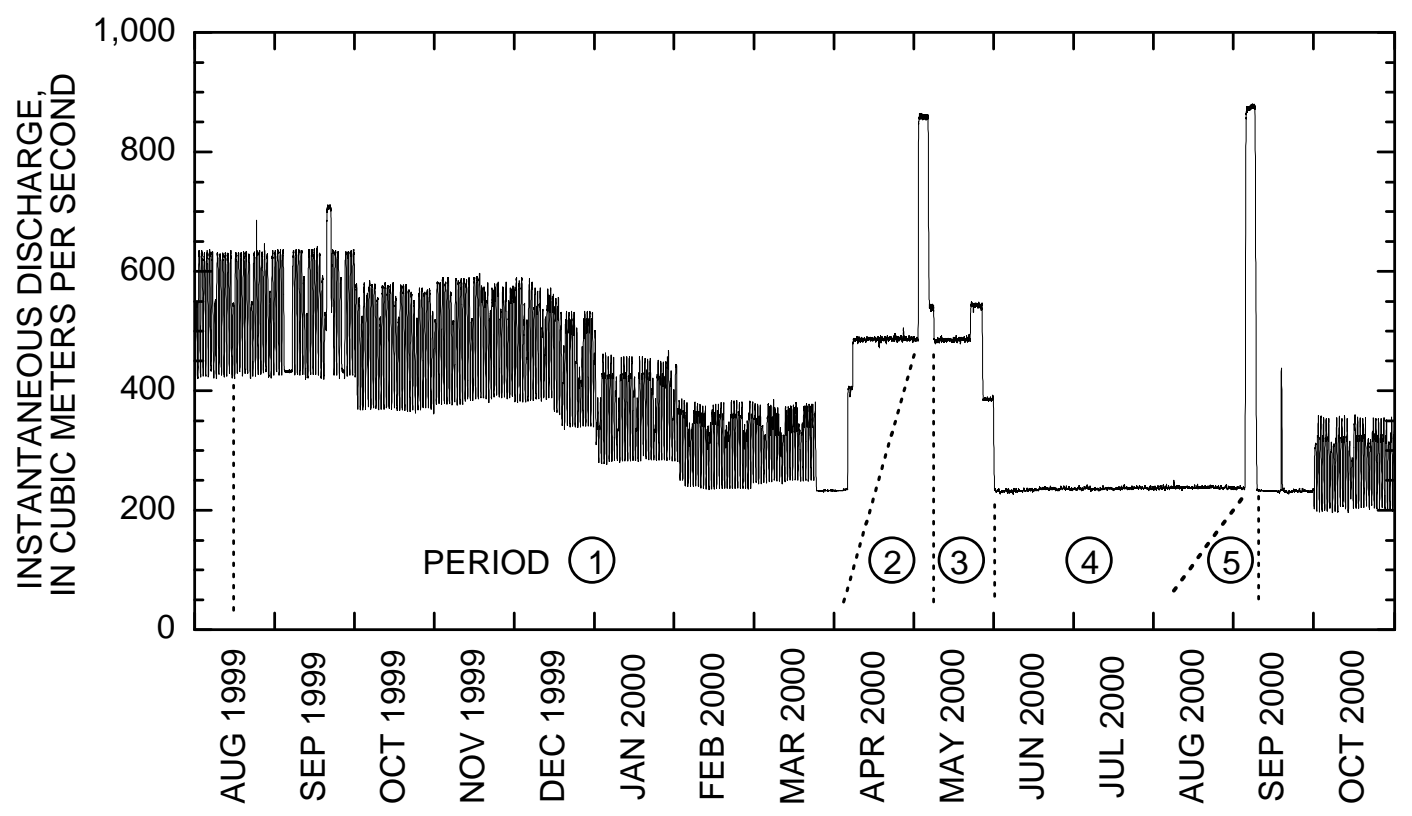

Figure 4. Hydrograph showing releases from Glen Canyon Dam (as measured at the Lees Ferry gaging station) throughout the six periods of the low summer steady flows (LSSF) experiment. 


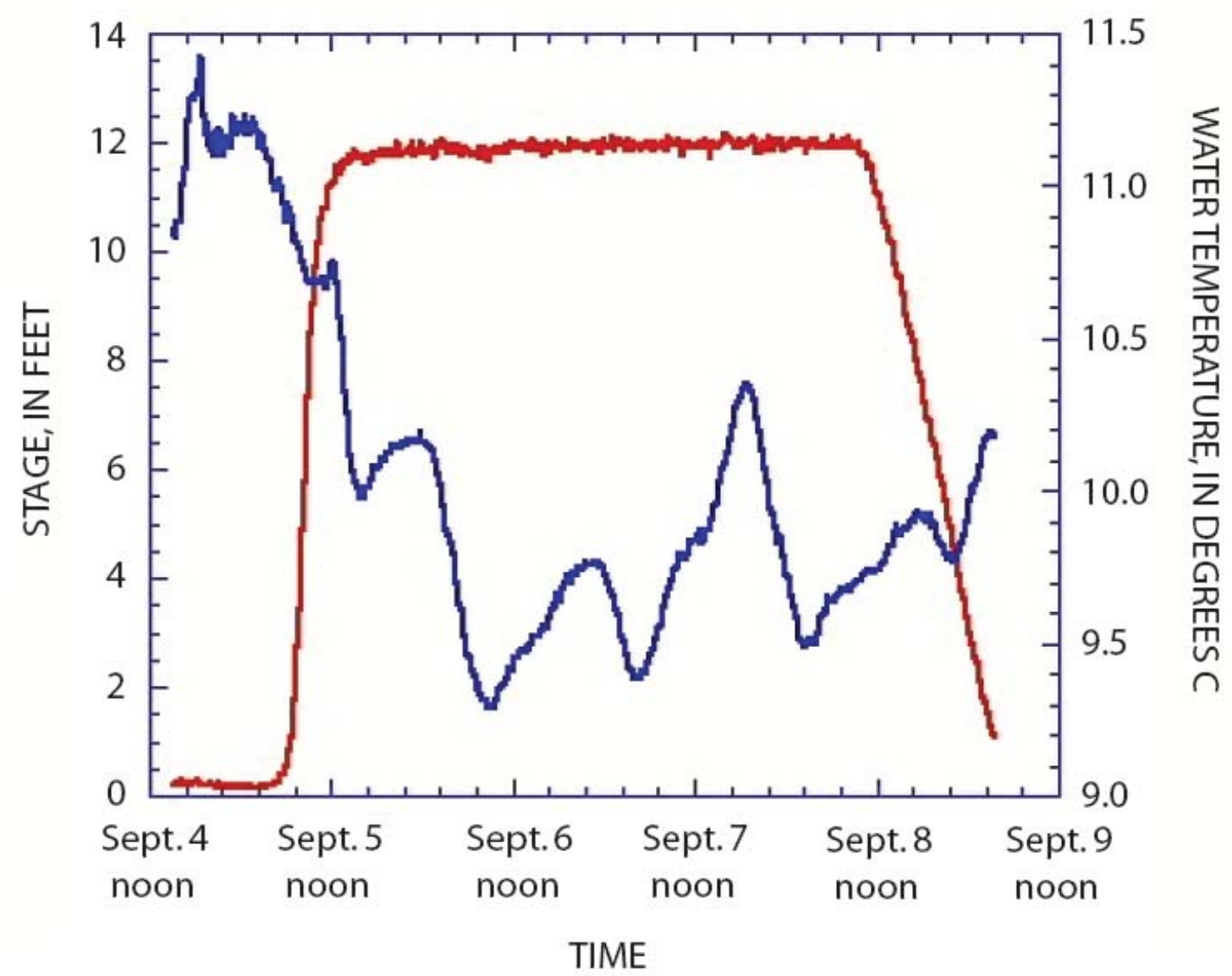

Figure 5. Stage and temperature at river mile 30.7 during the September 2000 habitat maintenance flows. These measurements were made every 15 minutes at a temporary stage gage installed on river left across from the sandbar. 
A.

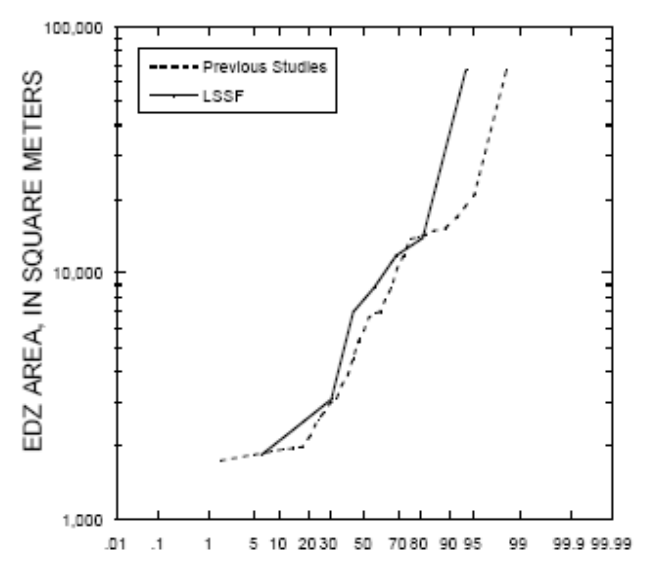

PERCENT SMALLER THAN INDICATED AREA

C.

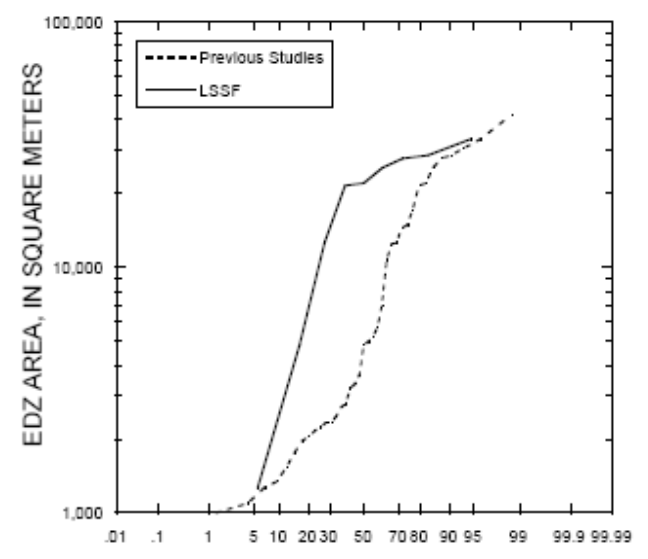

PERCENT SMALLER THAN INDICATED AREA

E.

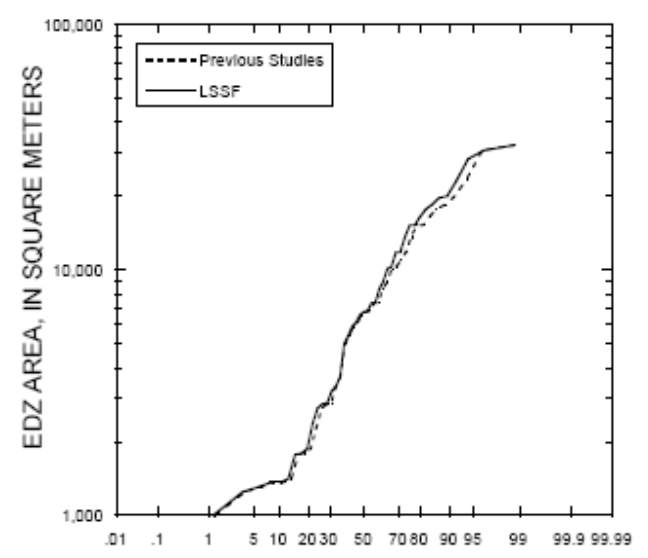

PERCENT SMALLER THAN INDICATED AREA
B.

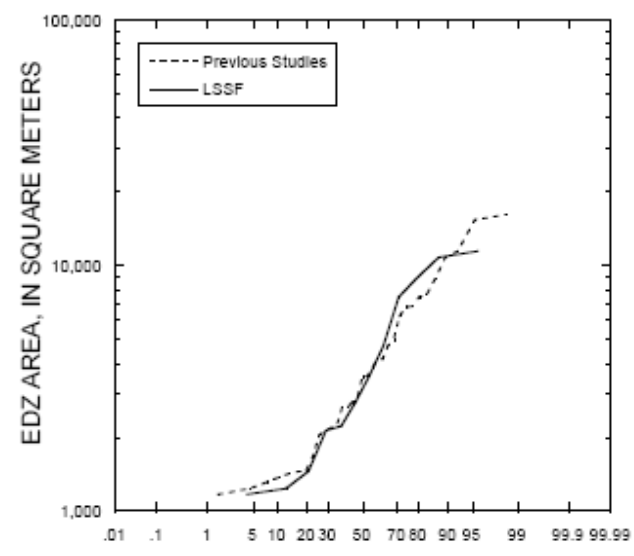

PERCENT SMALLER THAN INDICATED AREA

D.

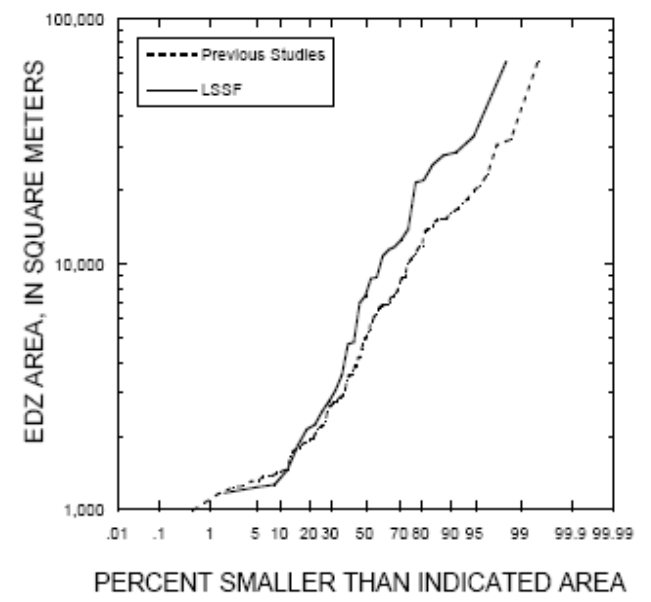

Figure 6. Cumulative size distributions of eddies in previous studies and low summer steady flows reaches. (A) Lees Ferry study reach. (B) Redwall Gorge study reach. (C) Point Hansbrough study reach. (D) Marble Canyon aggregated sample. (E) Tapeats Gorge study reach. 


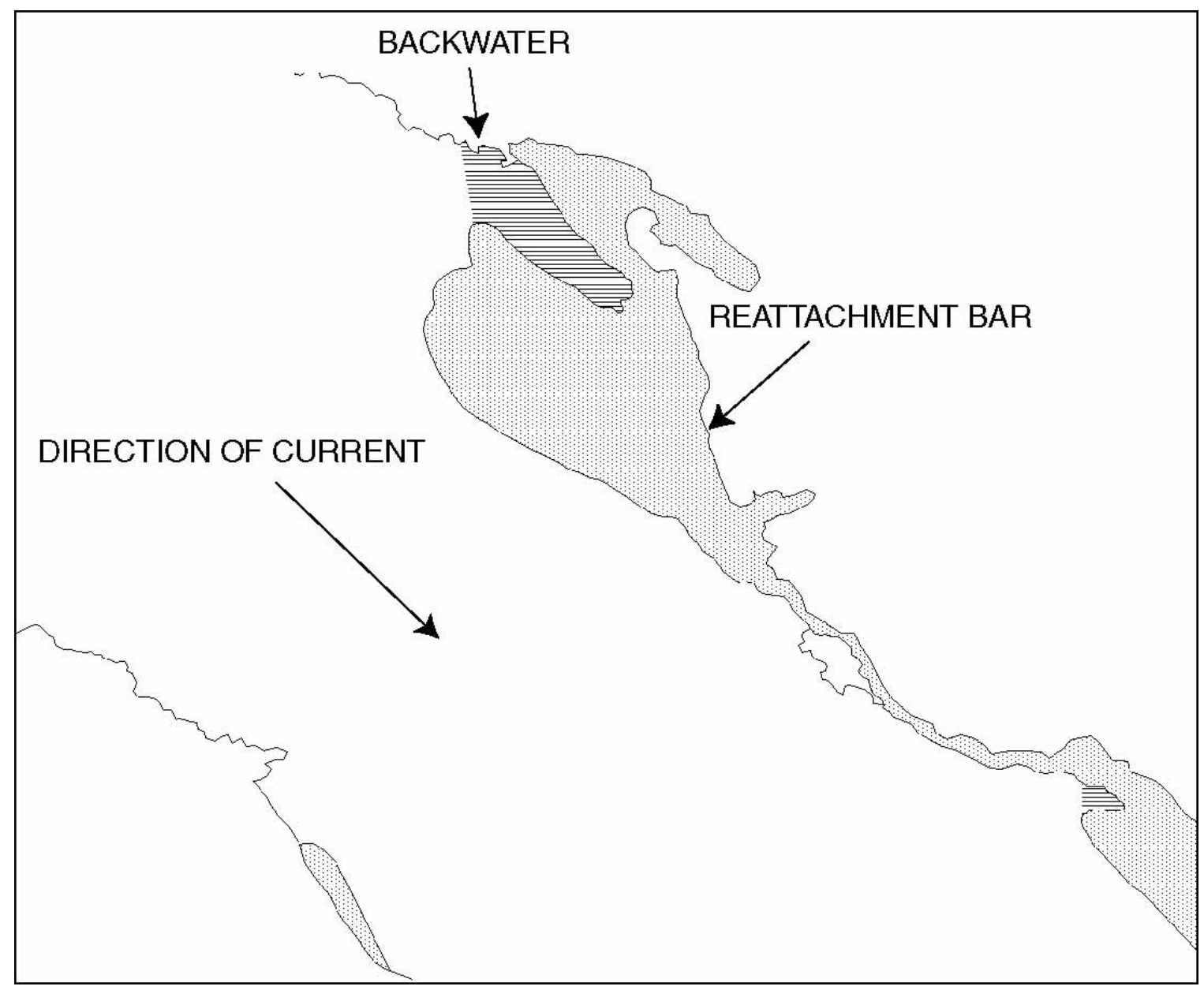

Figure 7. Diagram showing a sample backwater opening in the upstream direction. The upstream boundary of the backwater was drawn at an angle of approximately $45^{\circ}$ with respect to the maincurrent direction. 

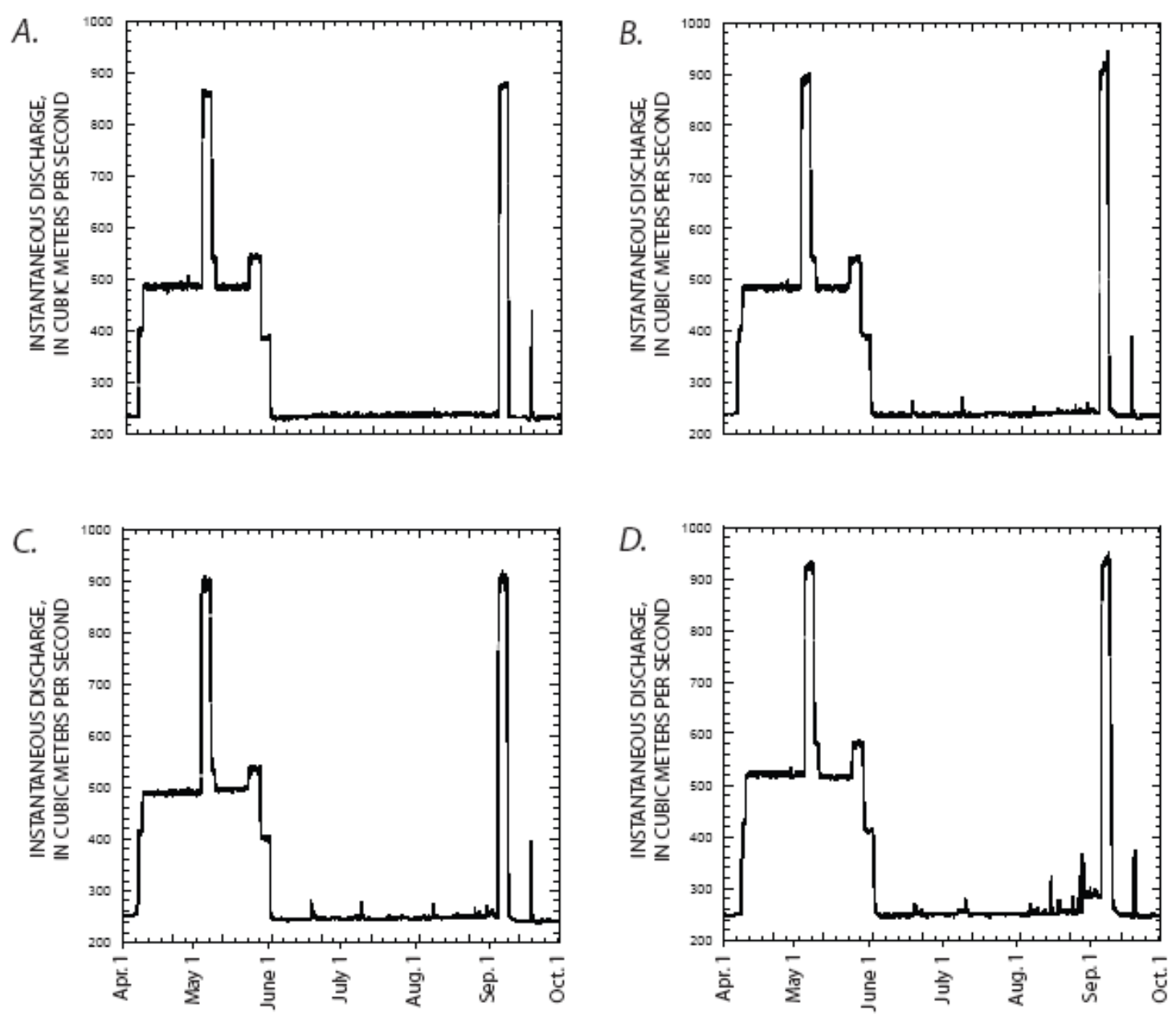

Figure 8. Hydrographs of the (A), Colorado River at the Lees Ferry, (B) Lower Marble Canyon, (C) Grand Canyon, and (D) Diamond Creek gaging stations from April 1-October 1, 2000. 
A.

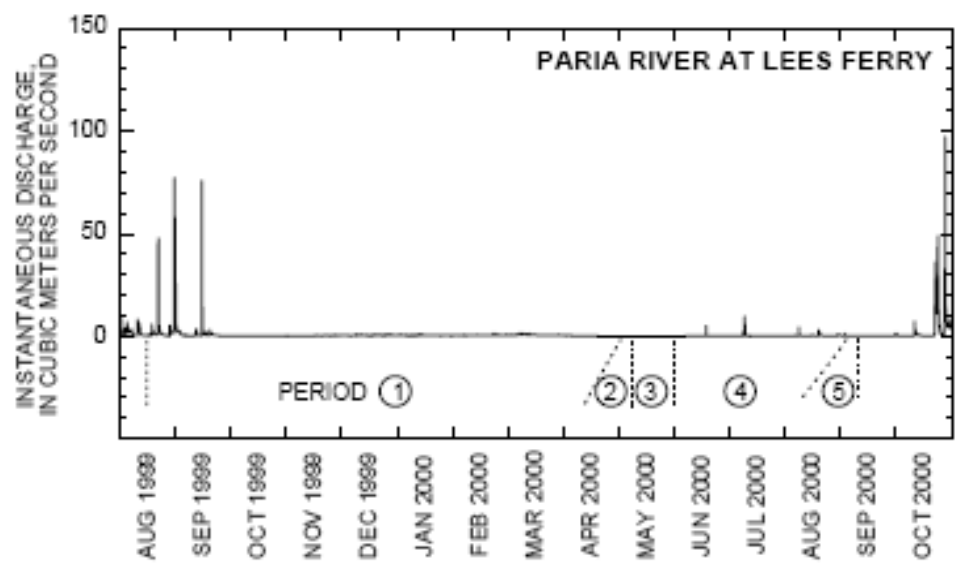

B.

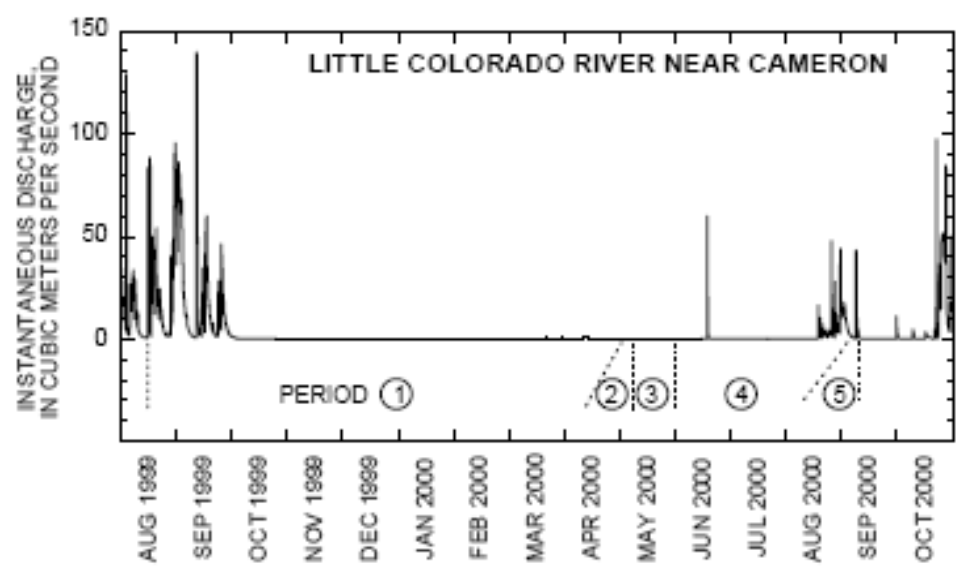

C.

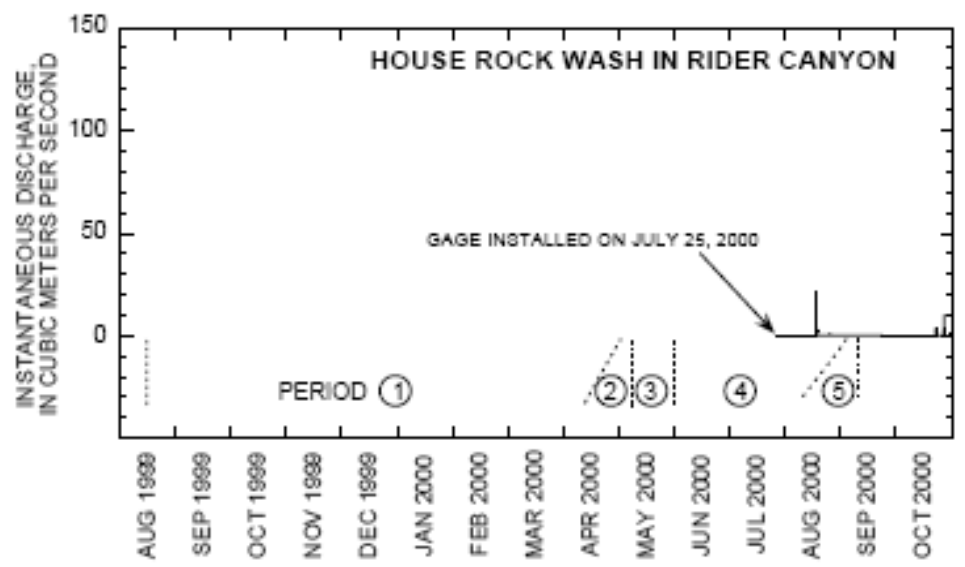

Figure 9. Hydrographs of three tributaries to the Colorado River: (A) the Paria River, (B) the Little Colorado River, and (C) House Rock Wash. 
A.

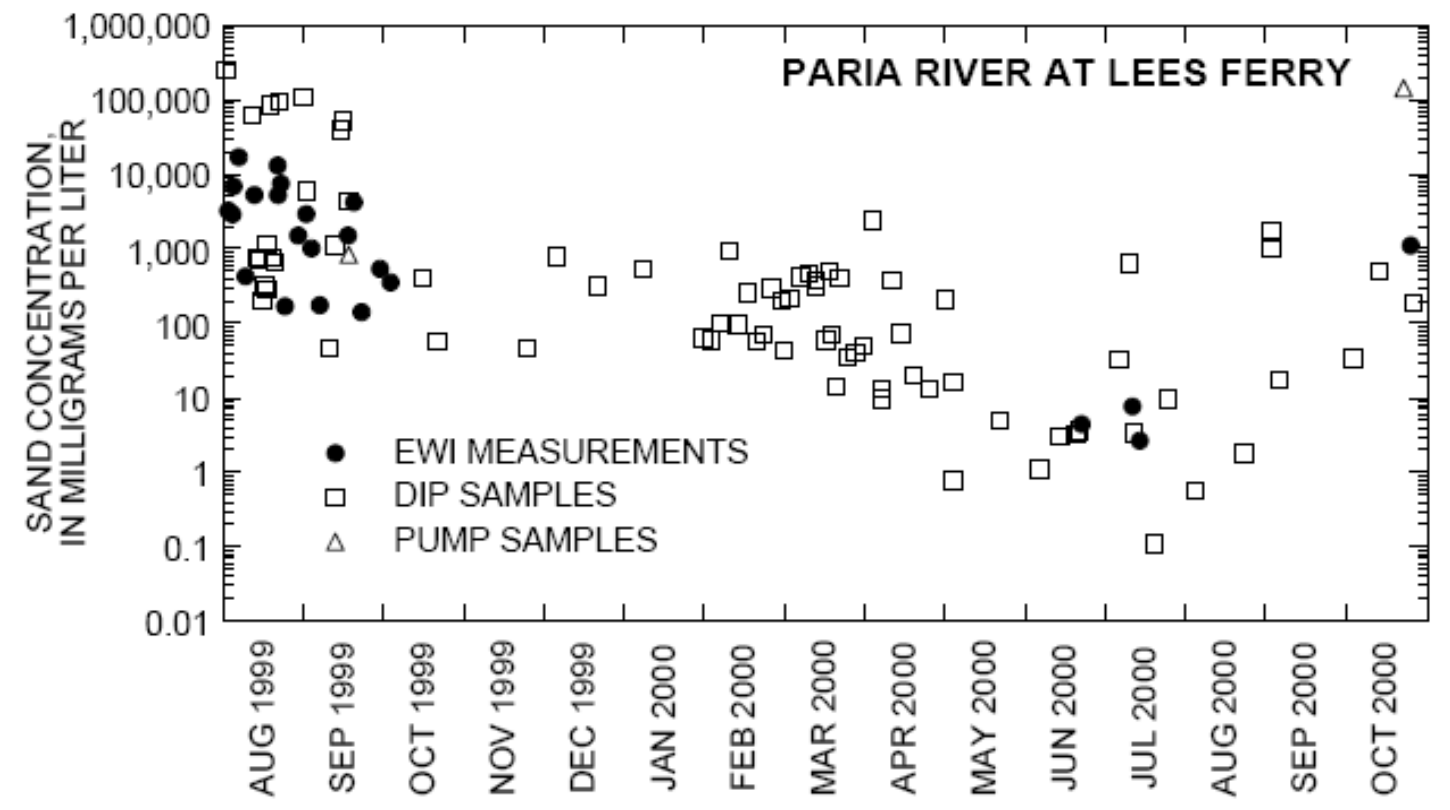

B.

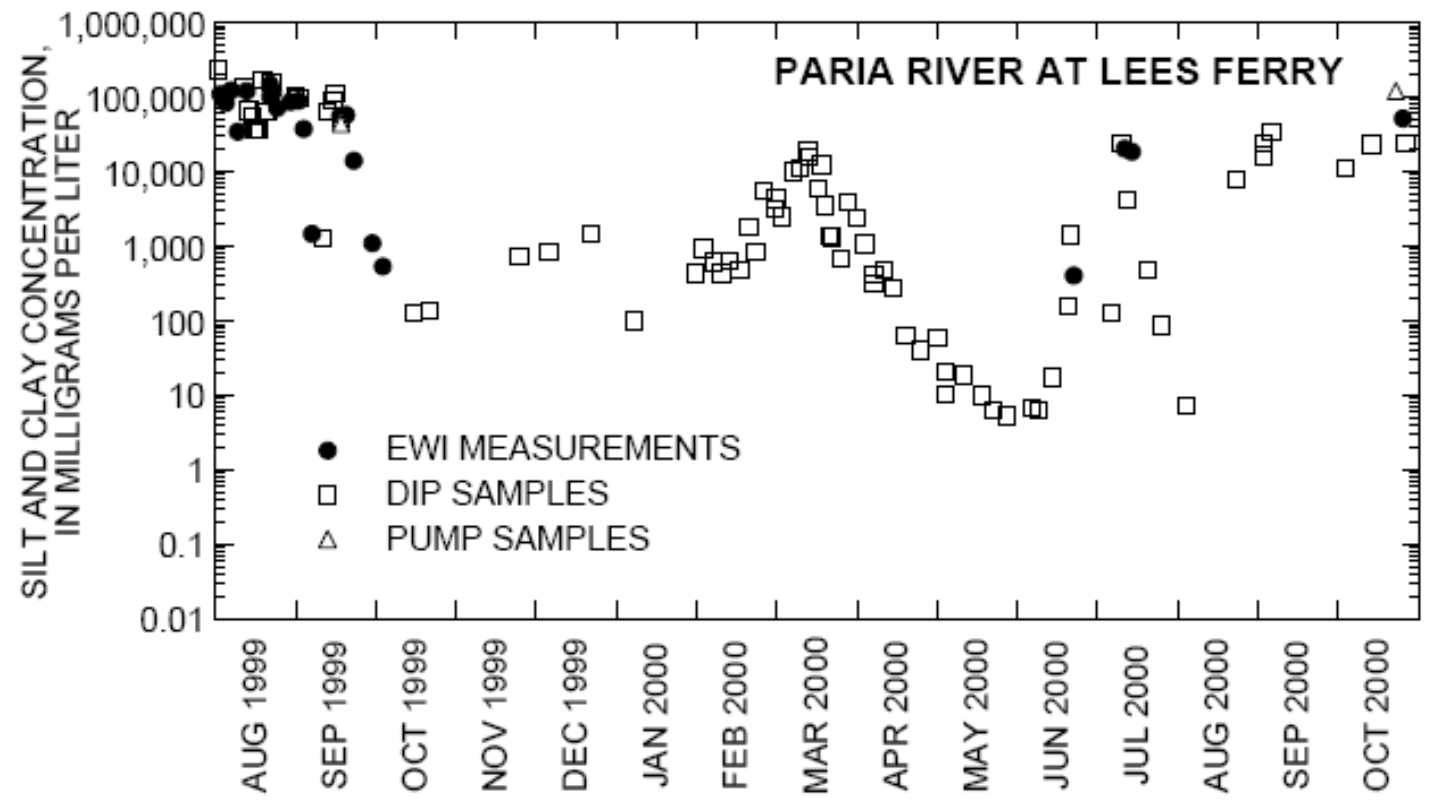

Figure 10. Measurements of (A) suspended-sand and (B) silt and clay concentrations at the Paria River at Lees Ferry gaging station during the study period. 


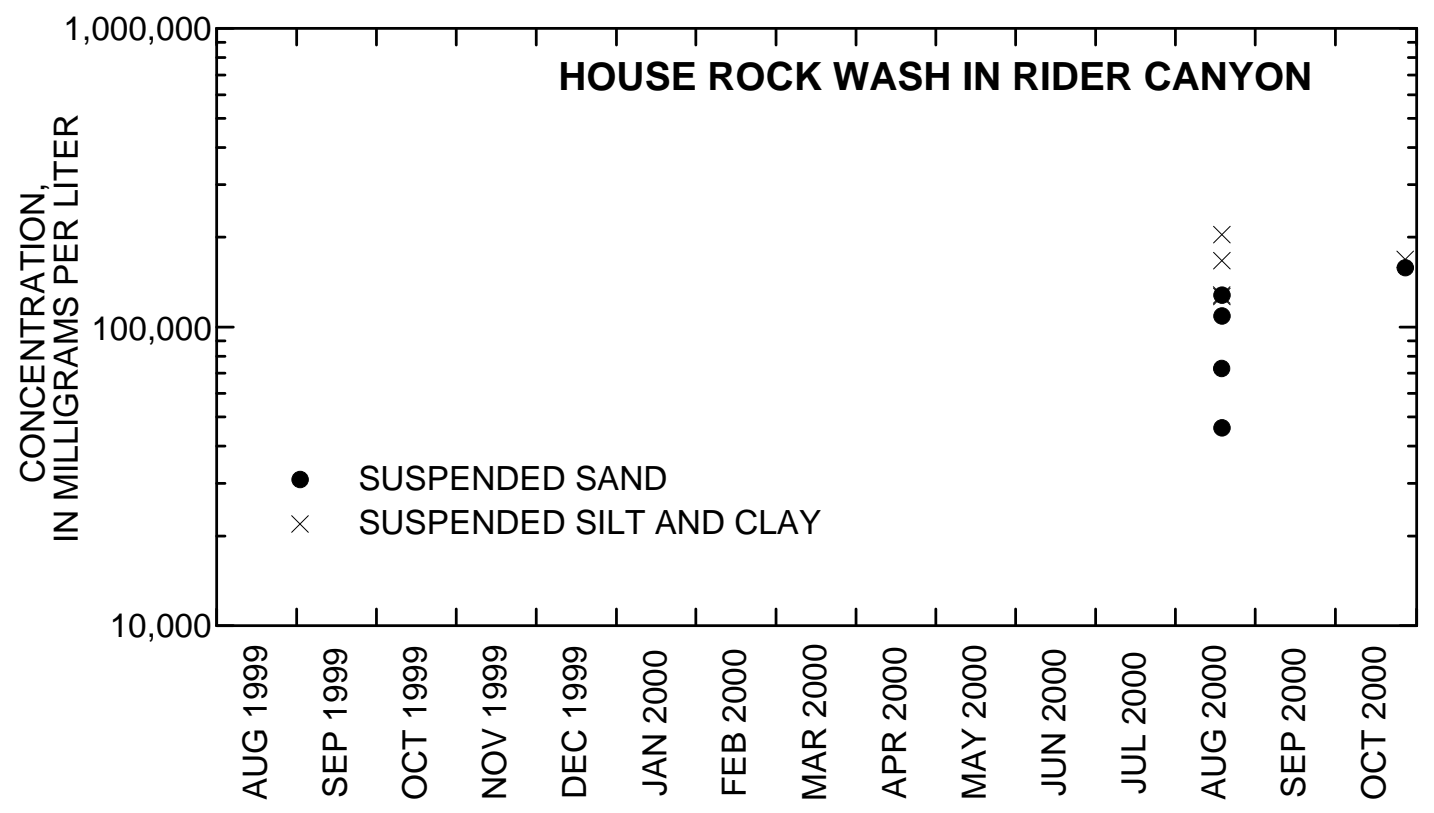

Figure 11. Measurements of suspended-sediment concentration in House Rock Wash during the study period. 
A.

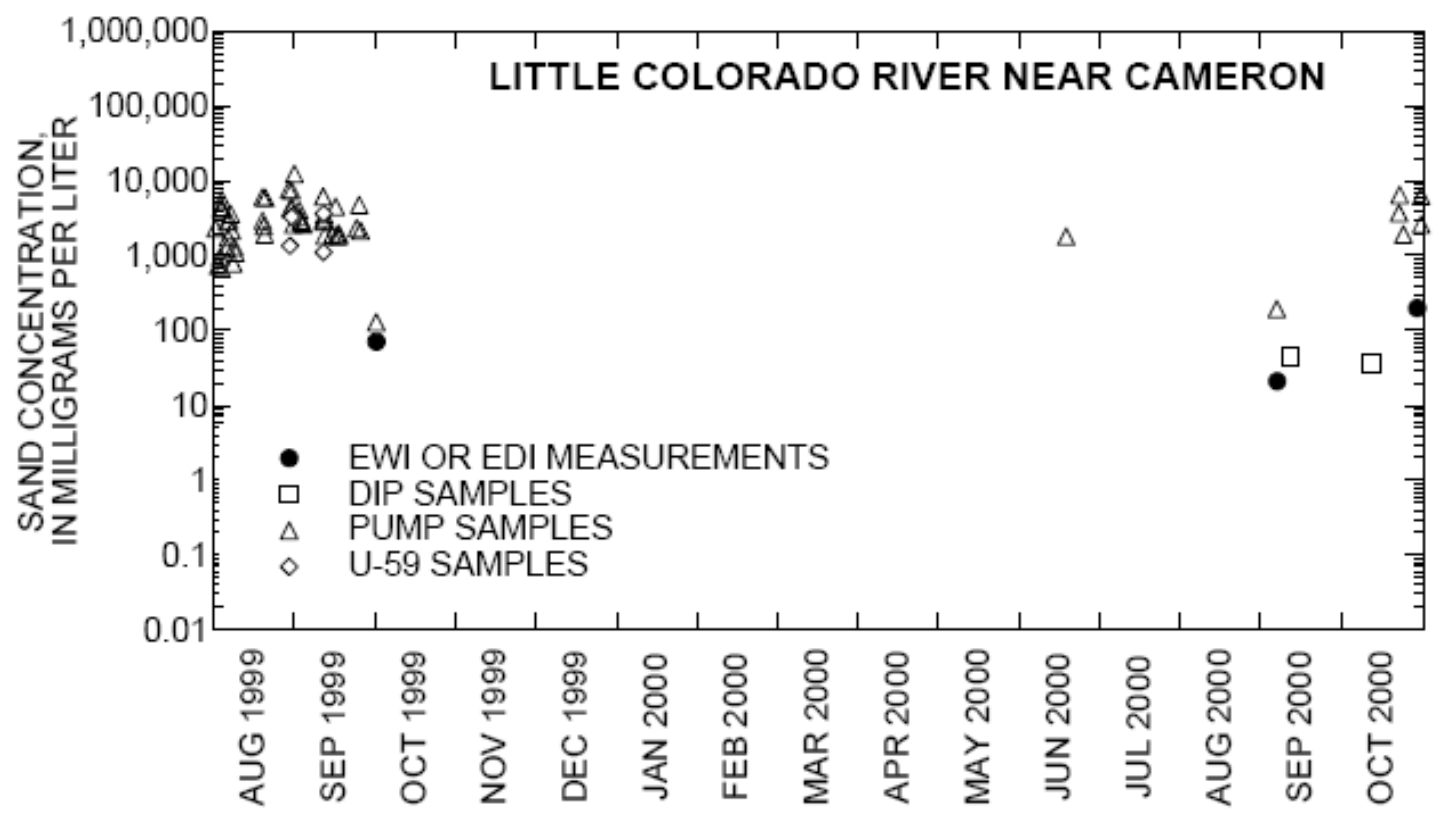

B.

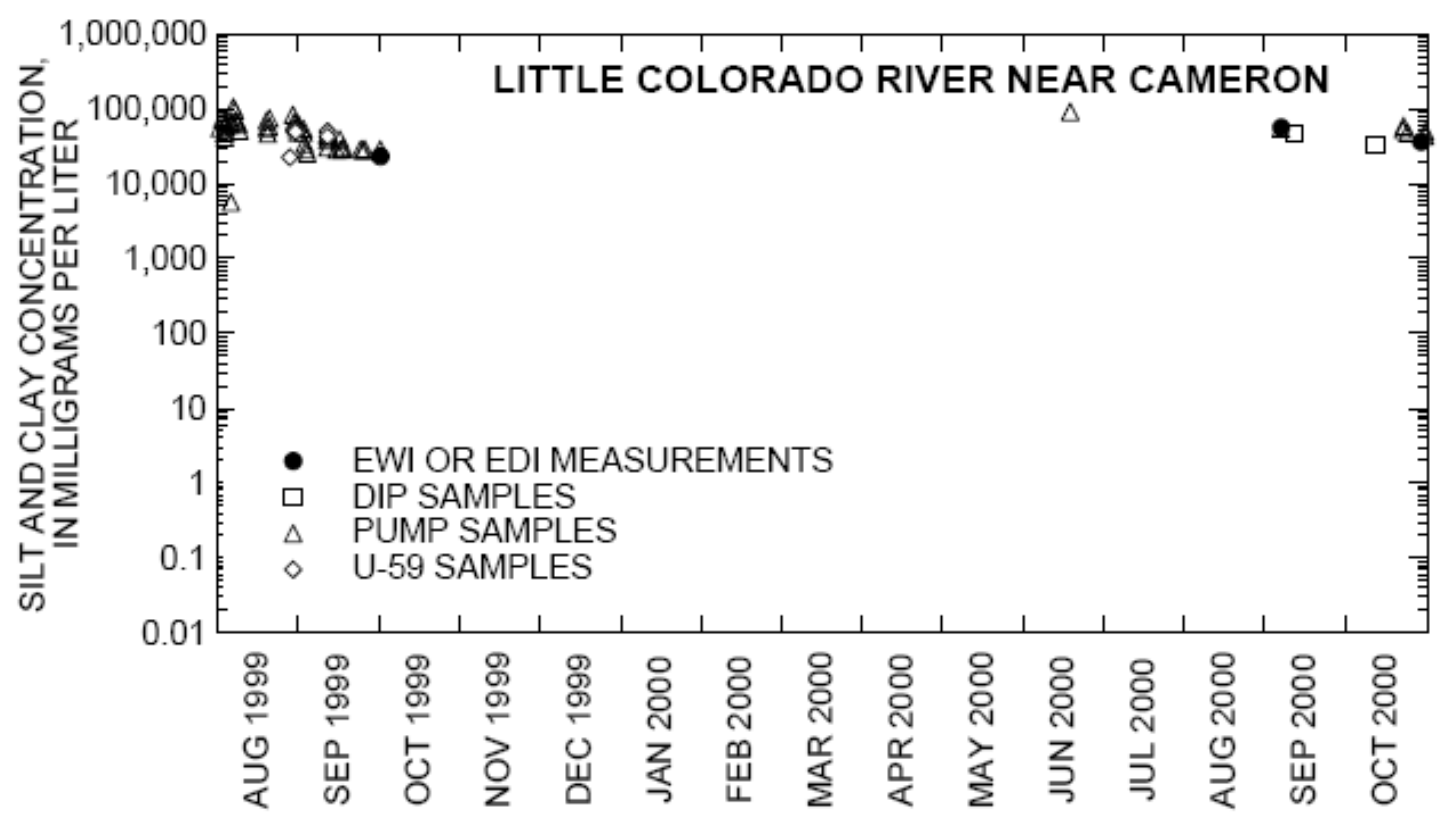

Figure 12. Measurements of (A) suspended-sand and (B) silt and clay concentrations at the Little Colorado River near Cameron, Ariz., during the study period. 


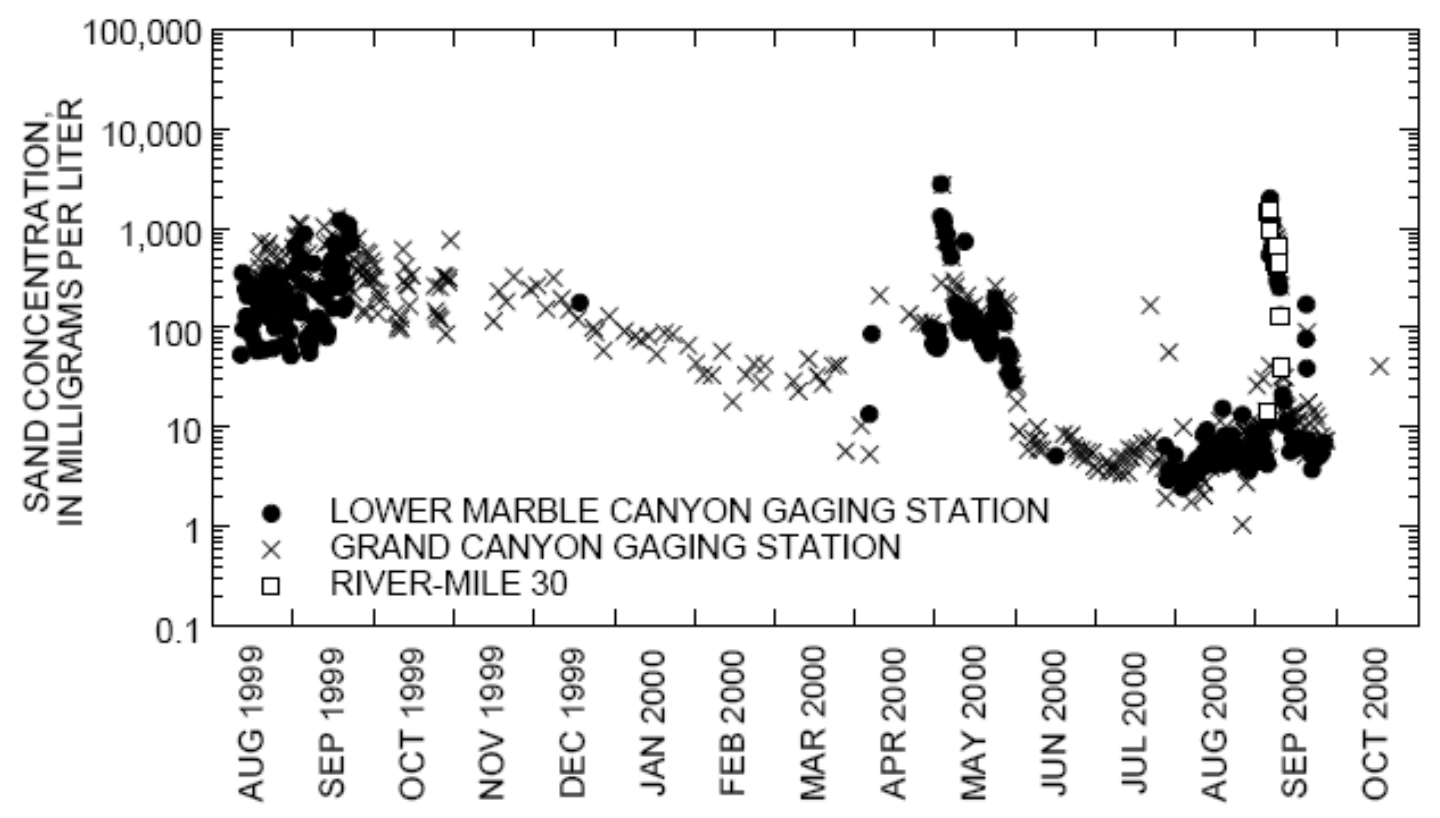

B.

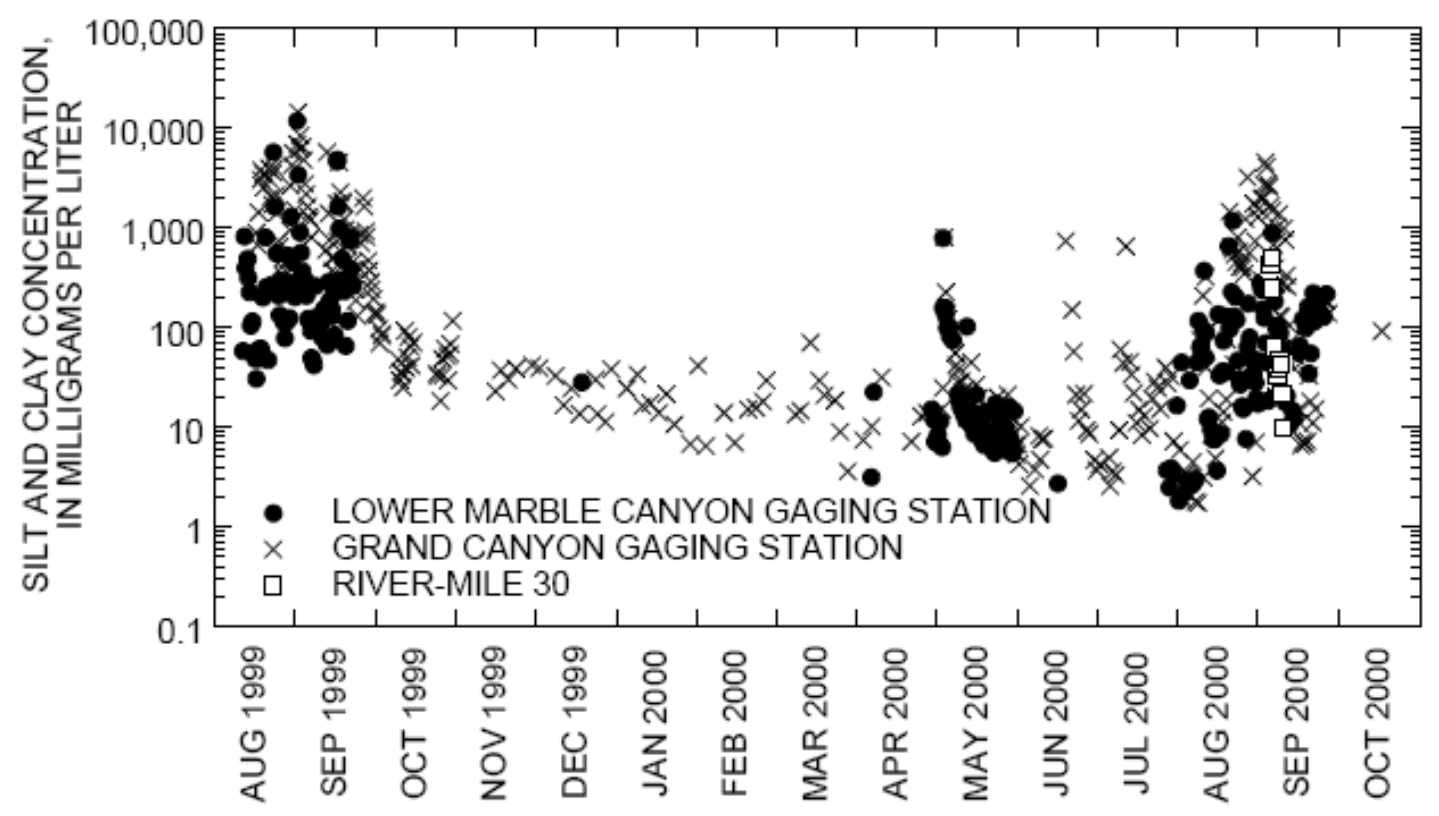

Figure 13. Measurements of (A) suspended-sand and (B) silt and clay concentrations in the Colorado River at the Lower Marble Canyon and Grand Canyon gaging stations during the study period. 
A.

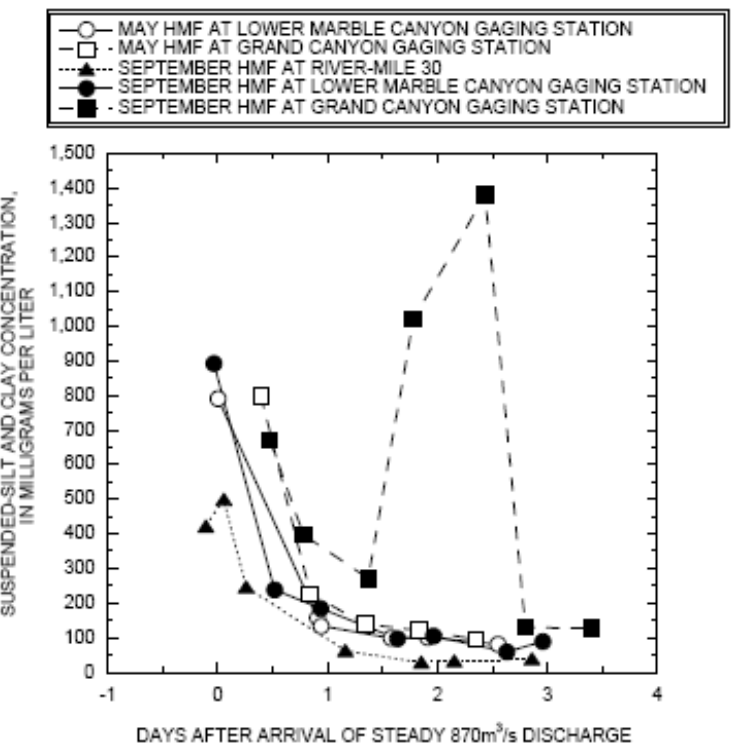

c.

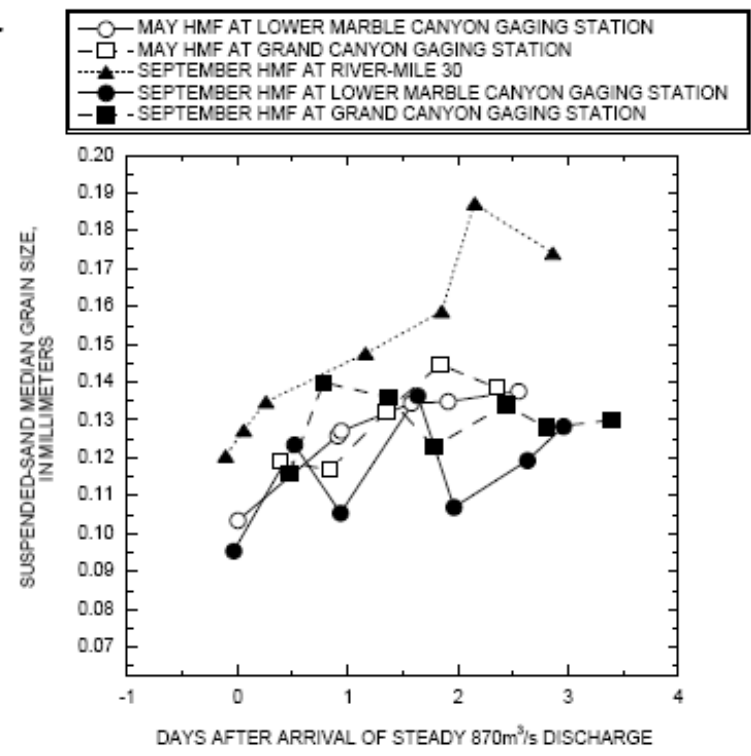

B.

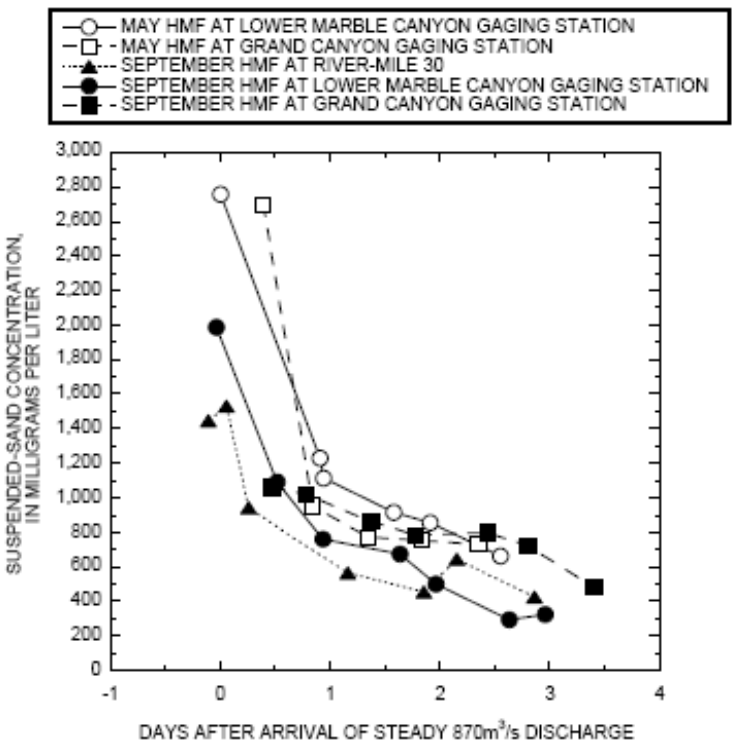

Figure 14. Measurements of (A) suspended-silt and clay concentration, $(B)$ suspended-sand concentration, and $(C)$ median grain size of suspended sand during the May and September habitat maintenance flows (HMF). 
A.

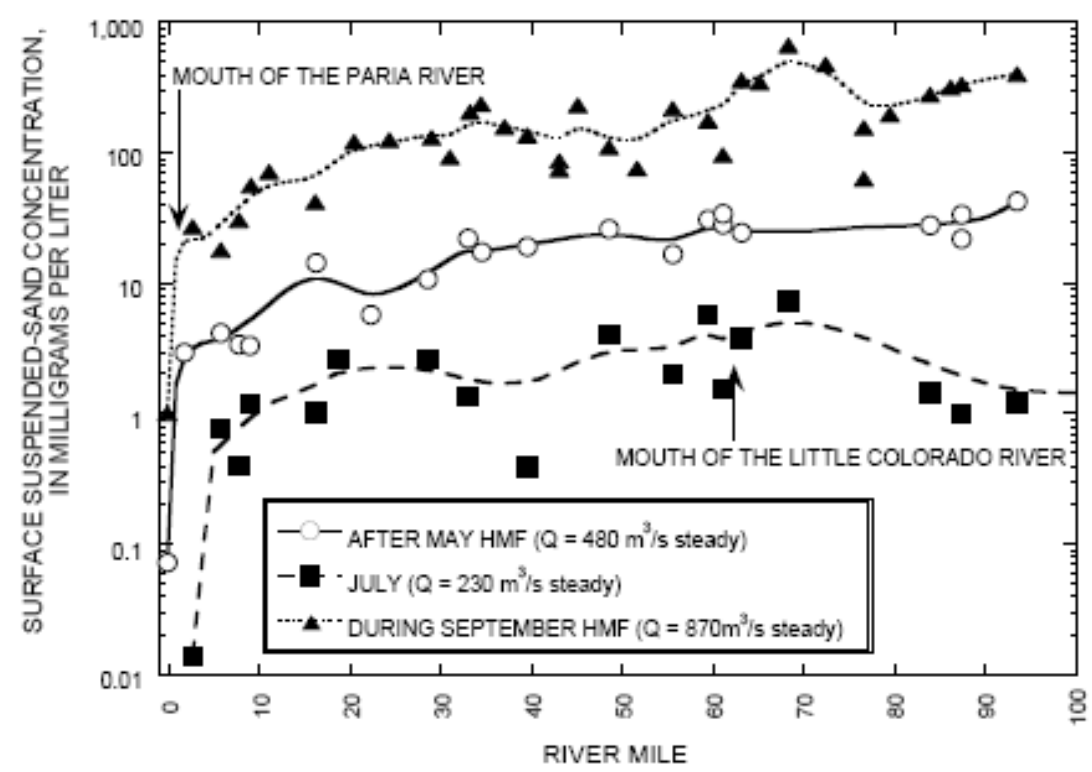

$B$.

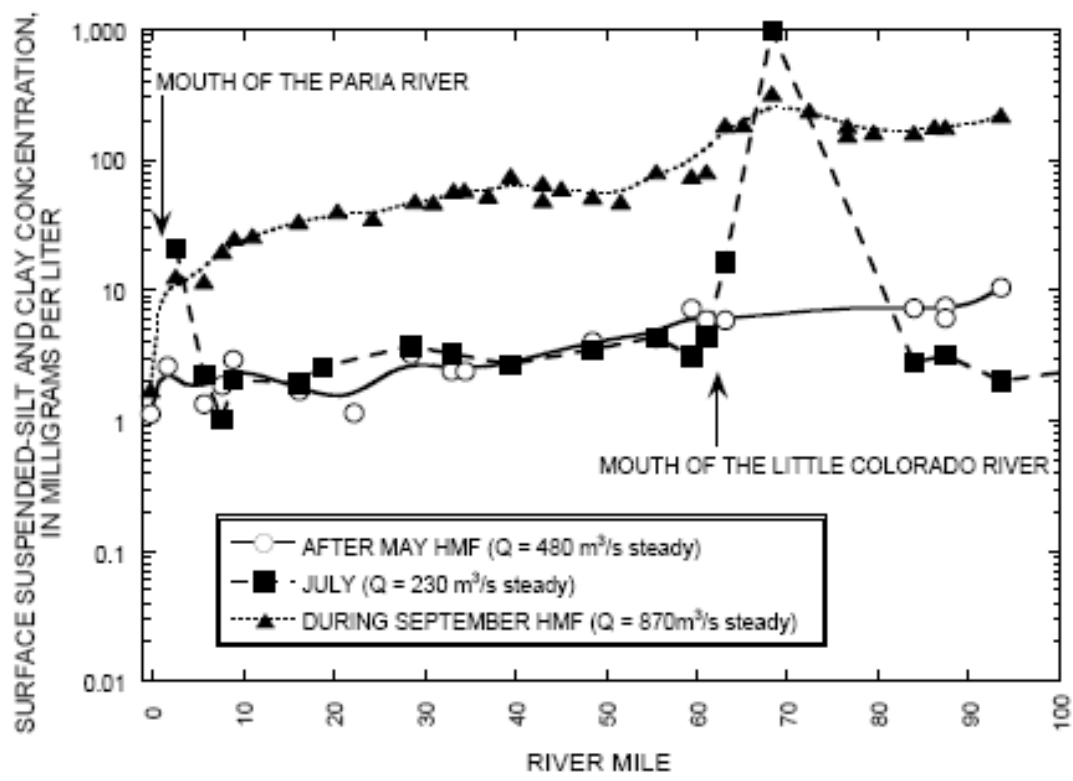

Figure 15. Measured surface (A) suspended-sand and (B) silt and clay concentrations (with smoothed curves) during May, July, and September 2000. 
A.

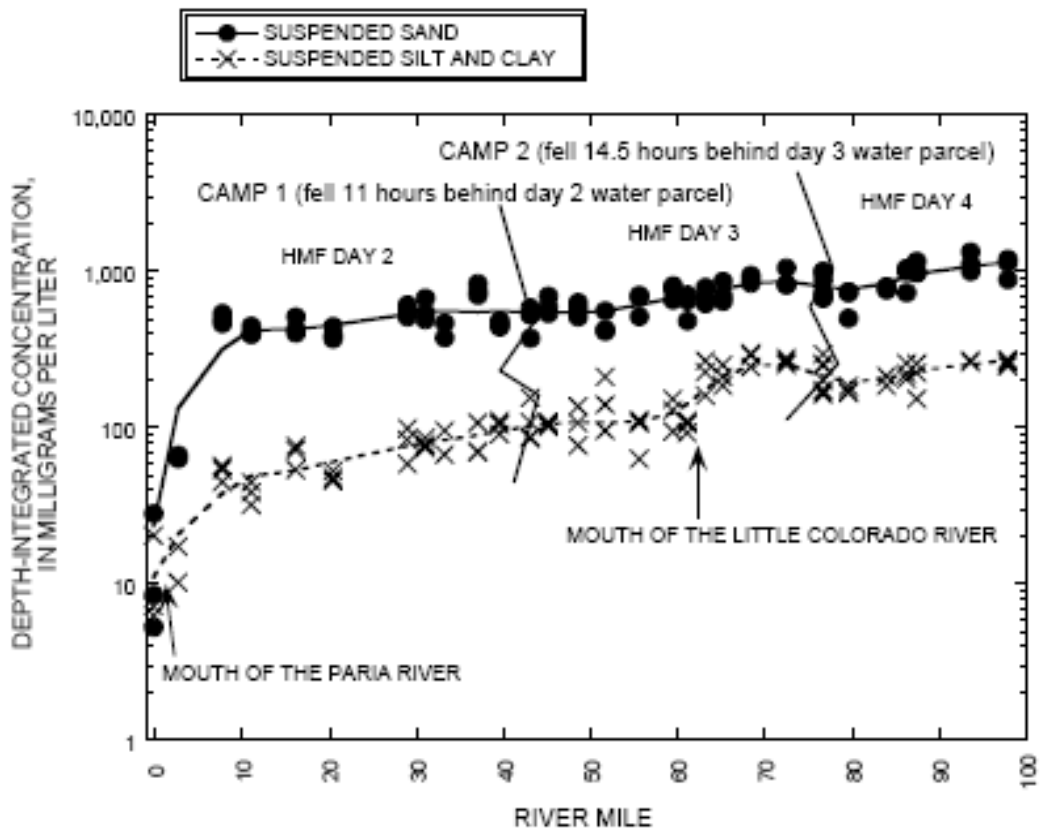

B.

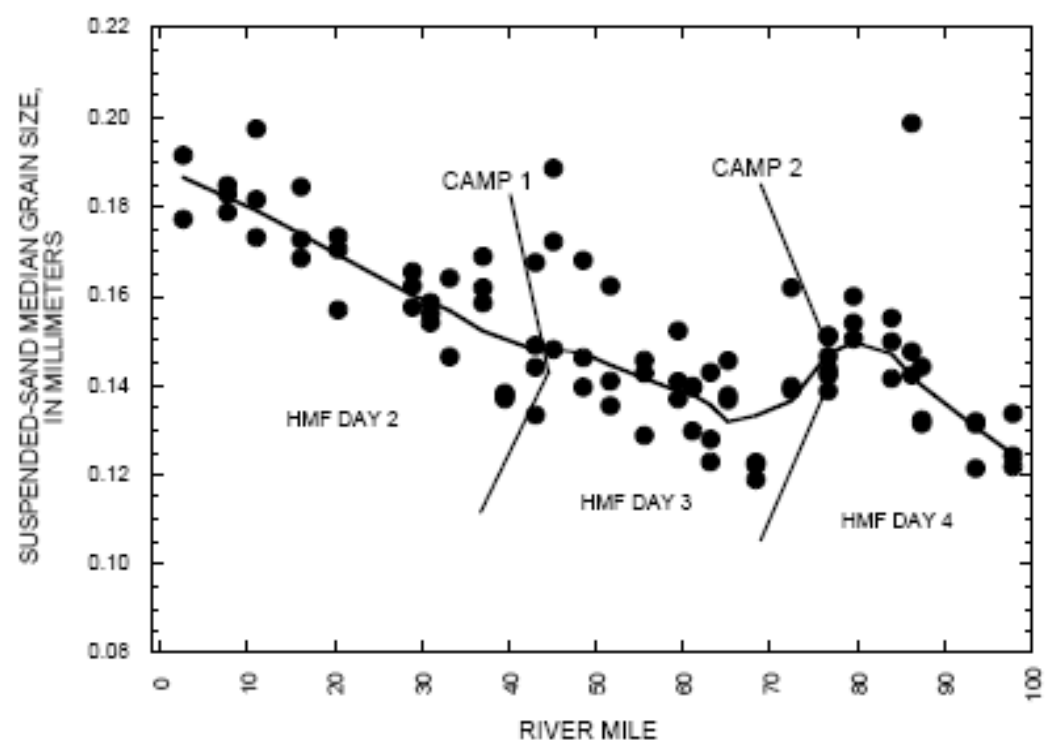

Figure 16. Depth-integrated measurements of suspended sediment (with smoothed curves) from the Lagrangian sampling trip during the September 2000 habitat maintenance flows (HMF). (A) Concentrations of suspended sand and suspended silt and clay. (B) Median grain size of suspended sand. 


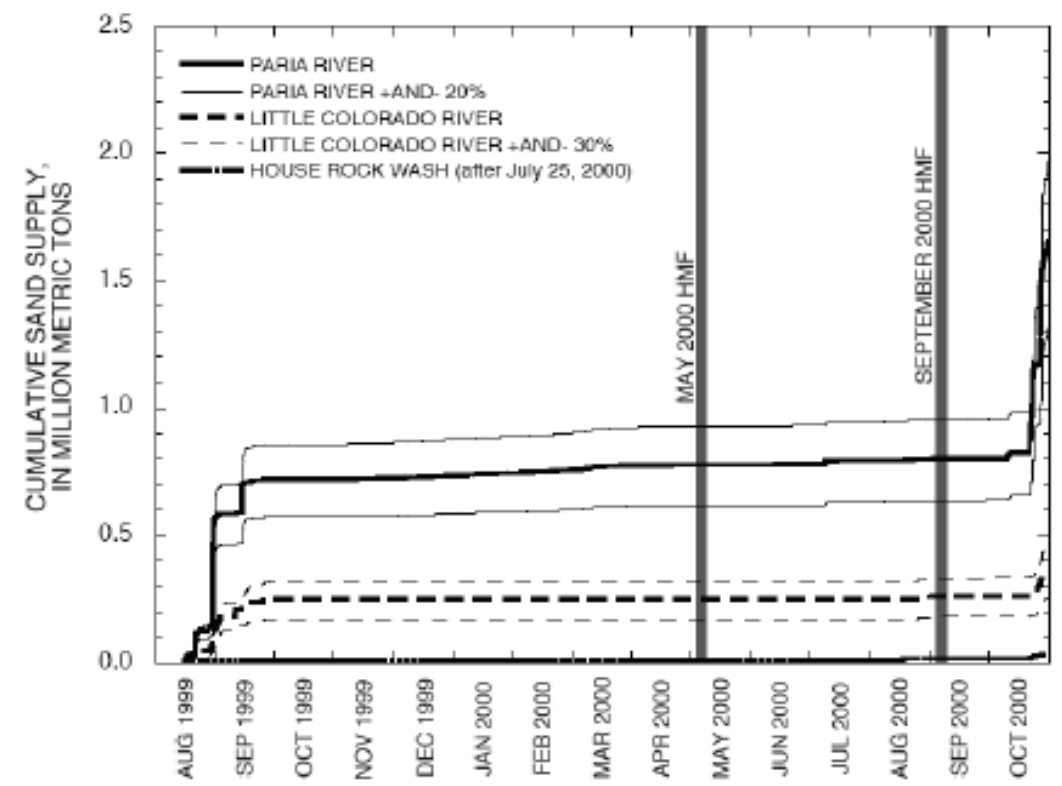

B.

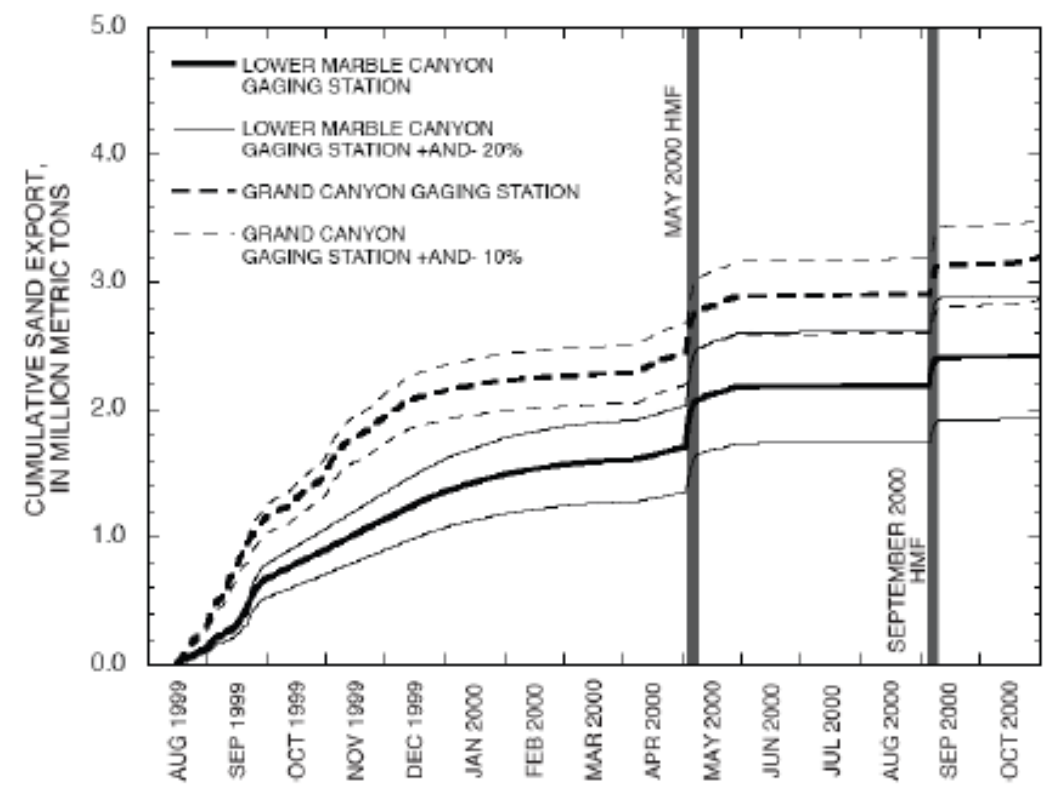

Figure 17. Computed cumulative sand transport during the study period. (A) Sand supply from the Paria River, Little Colorado River, and House Rock Wash. Uncertainties are shown for the Paria River and Little Colorado River sand supplies. (B) Sand export past the Lower Marble Canyon and Grand Canyon gaging stations, with uncertainties. 


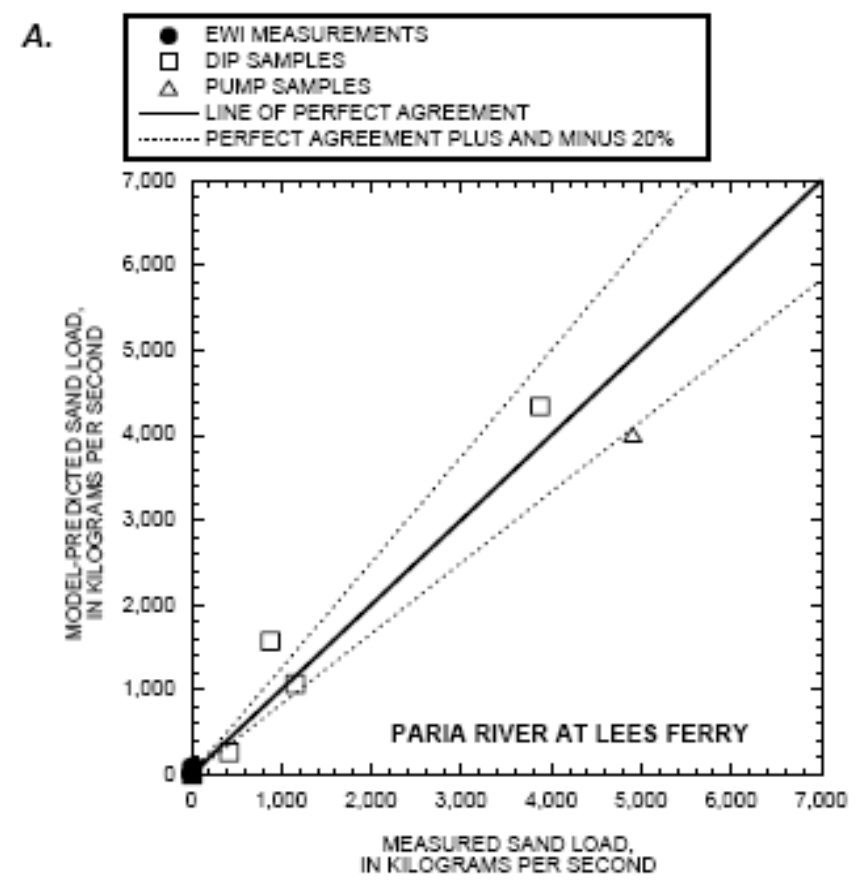

B.

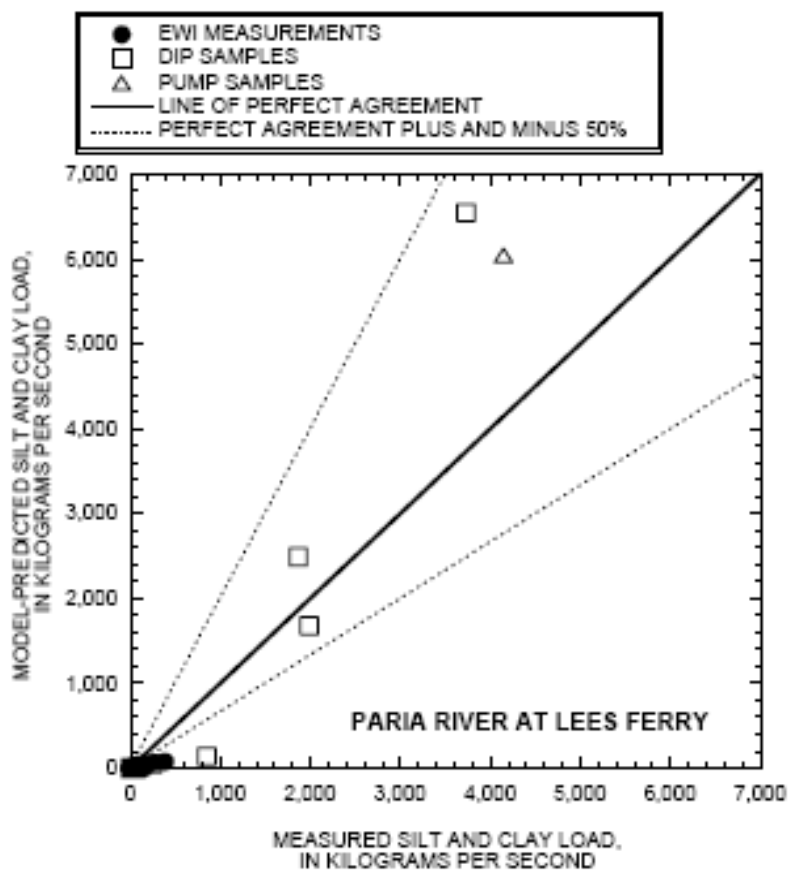

Figure 18. Model-predicted versus measured instantaneous $(A)$ sand and $(B)$ silt and clay loads in the Paria River at Lees Ferry during the study period. 


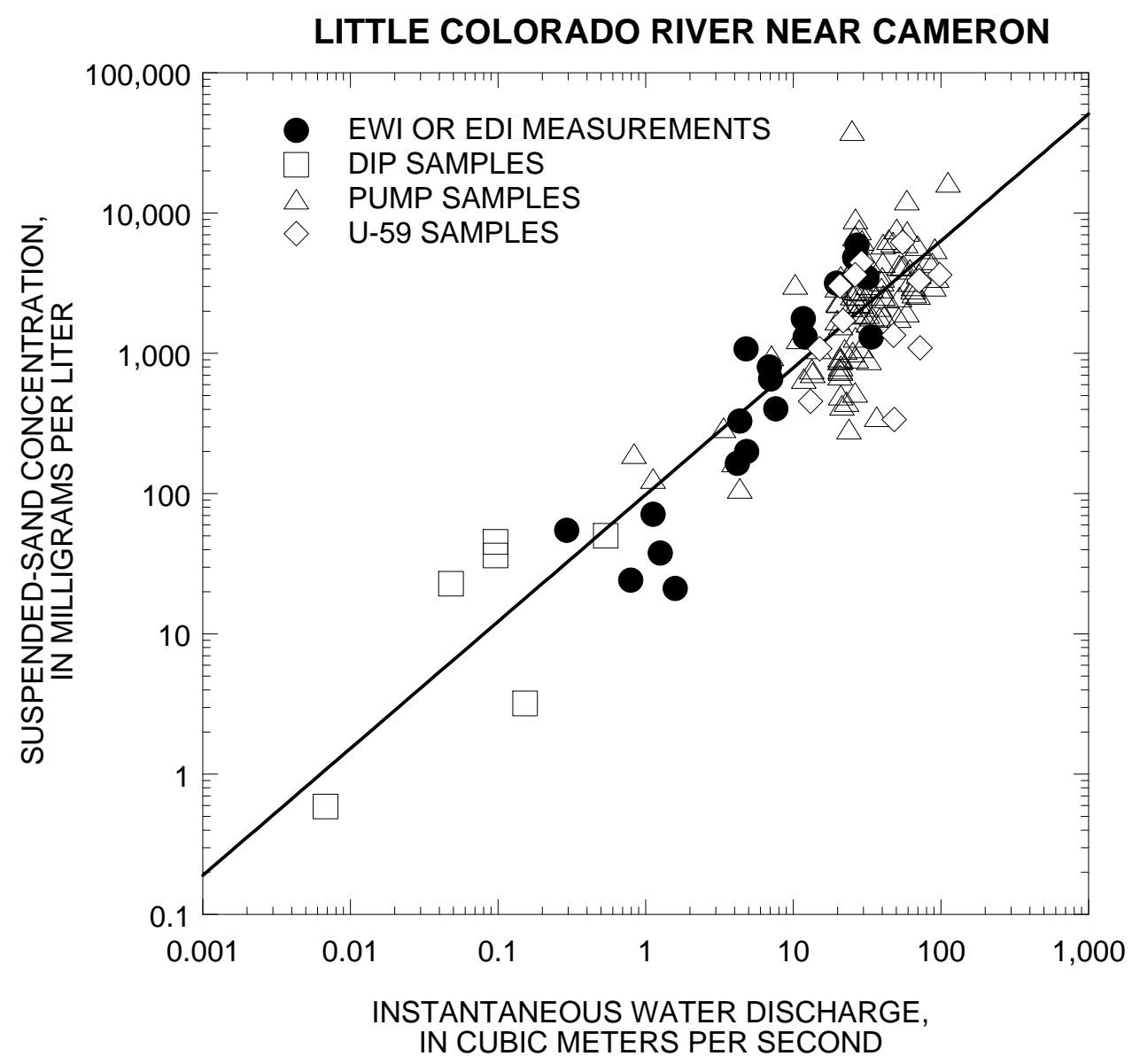

Figure 19. Suspended-sand rating curve used to estimate the concentration of suspended sand in the Little Colorado River. 
A.

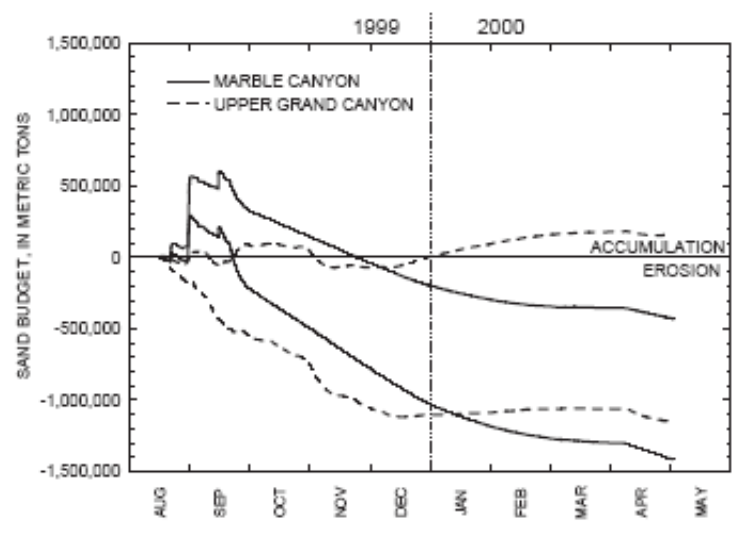

C.

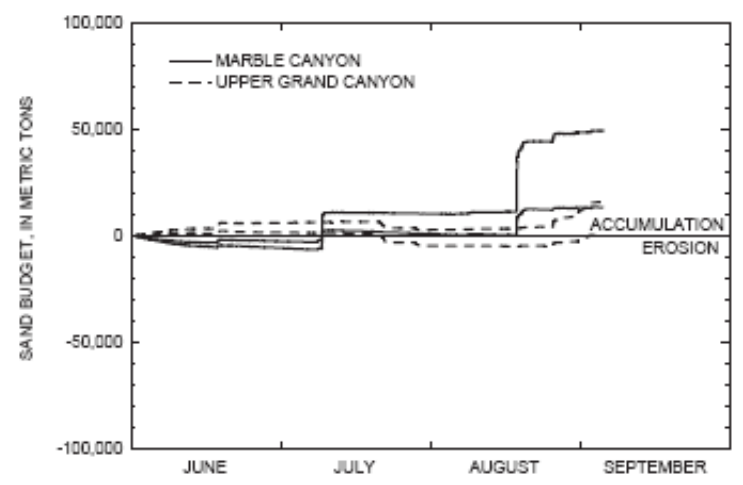

E.

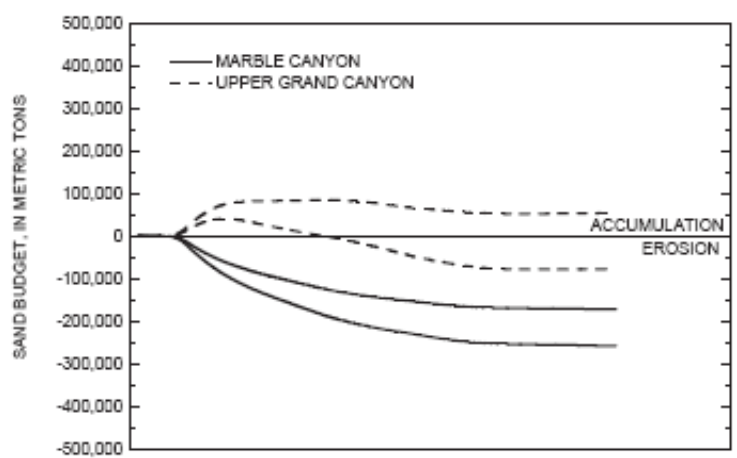

$B$.

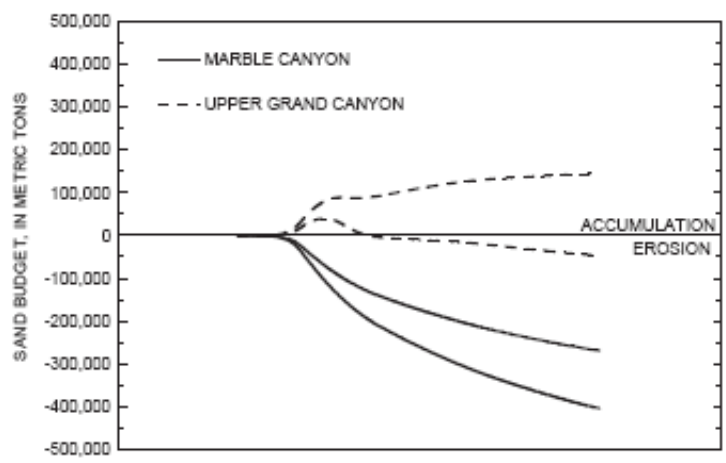

$D$.

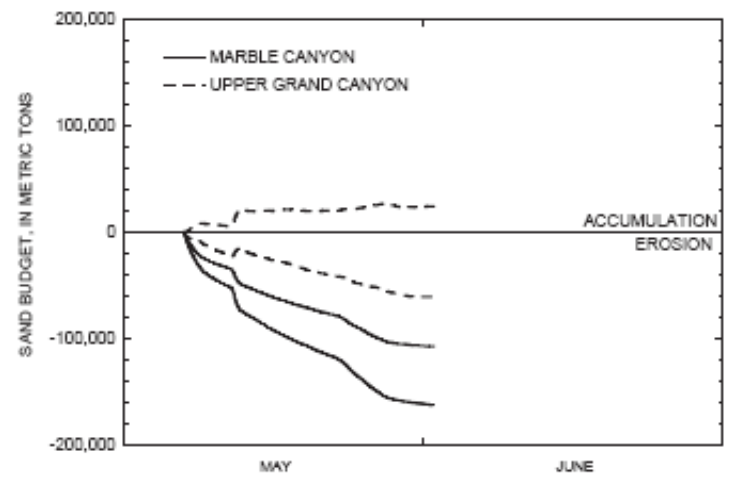

Figure 20. Mass-balance sand budget uncertainty envelopes for Marble Canyon and upper Grand Canyon during Periods 1-5. (A) Period 1, (B) Period 2 (May habitat maintenance flows), (C) Period 3, (D) Period 4, and (E) Period 5 (September habitat maintenance flows). The demonstrable sand mass balances in each reach lie within these uncertainty envelopes. 

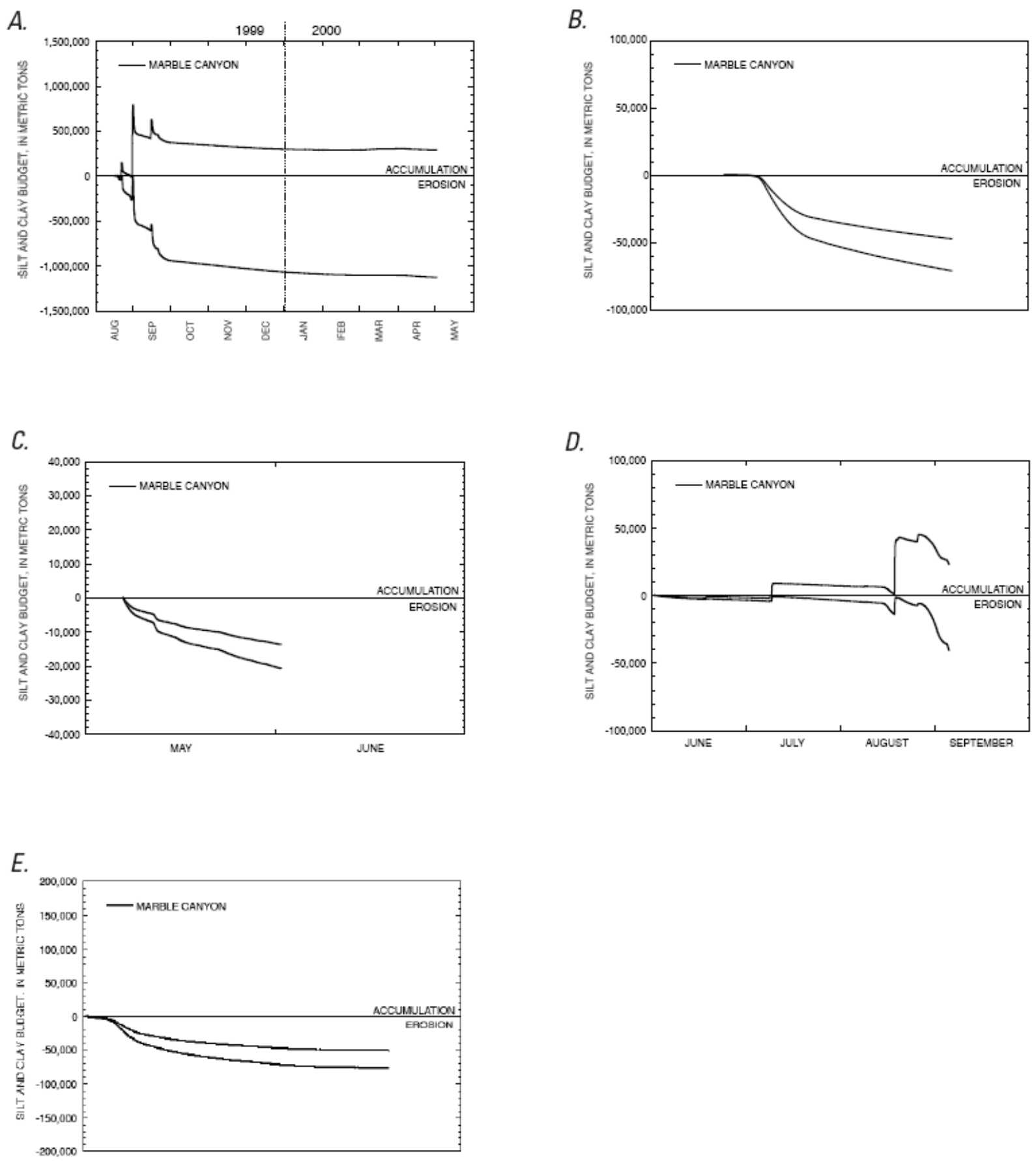

Figure 21. Mass-balance silt and clay budget uncertainty envelopes for Marble Canyon during Periods 1-5. (A) Period 1, (B) Period 2 (May habitat maintenance flows), (C) Period 3, (D) Period 4, and (E) Period 5 (September habitat maintenance flows). The demonstrable silt and clay mass balances in this reach lie within these uncertainty envelopes. 


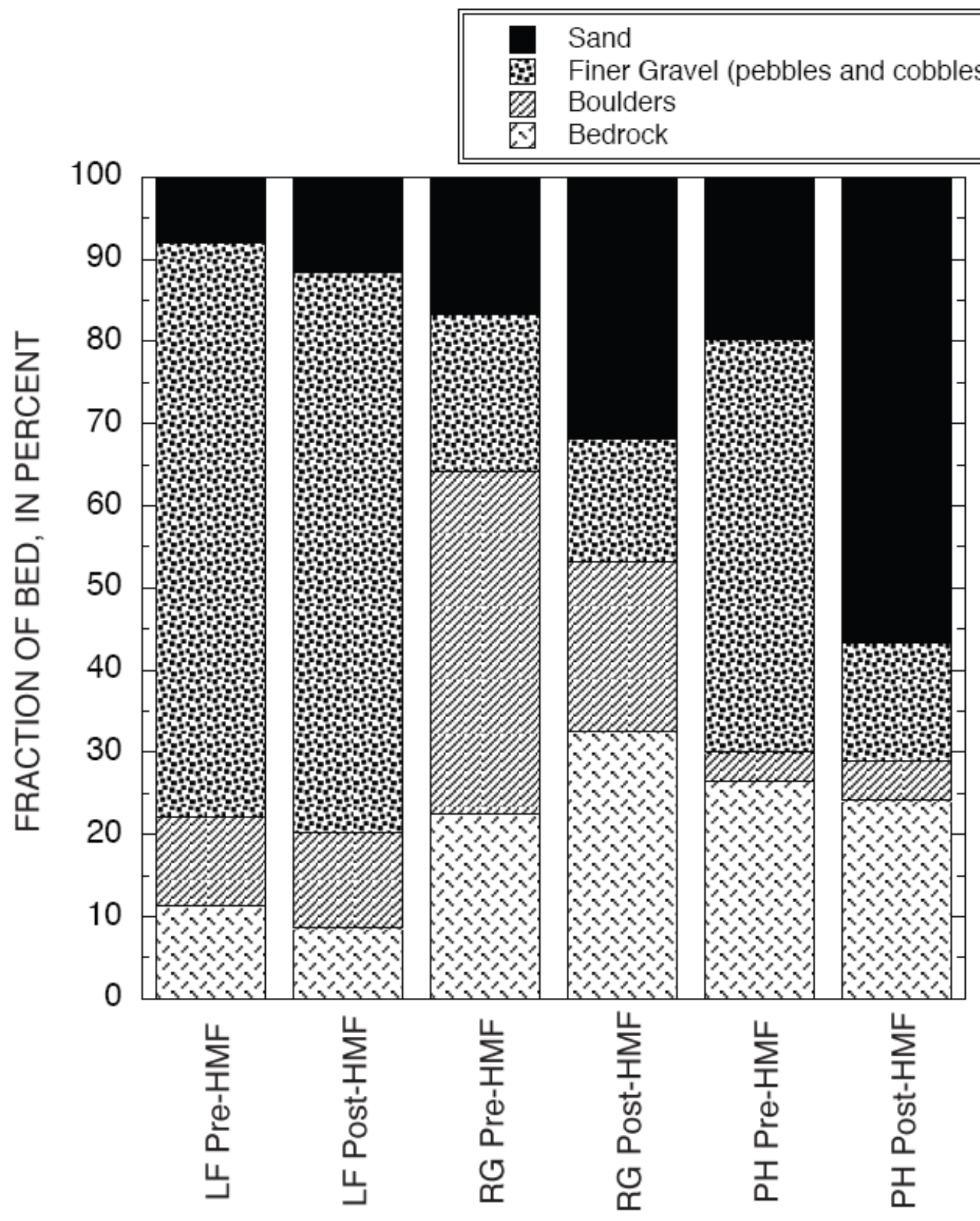

Figure 22. Fraction of bed area (in \%) composed of each bed-texture class before and after the September habitat maintenance flows (HMF) in the three study reaches in Marble Canyon, as determined from side-scan sonar data. LF is Lees Ferry study reach. RG is Redwall Gorge study reach. PH is Point Hansbrough study reach. 


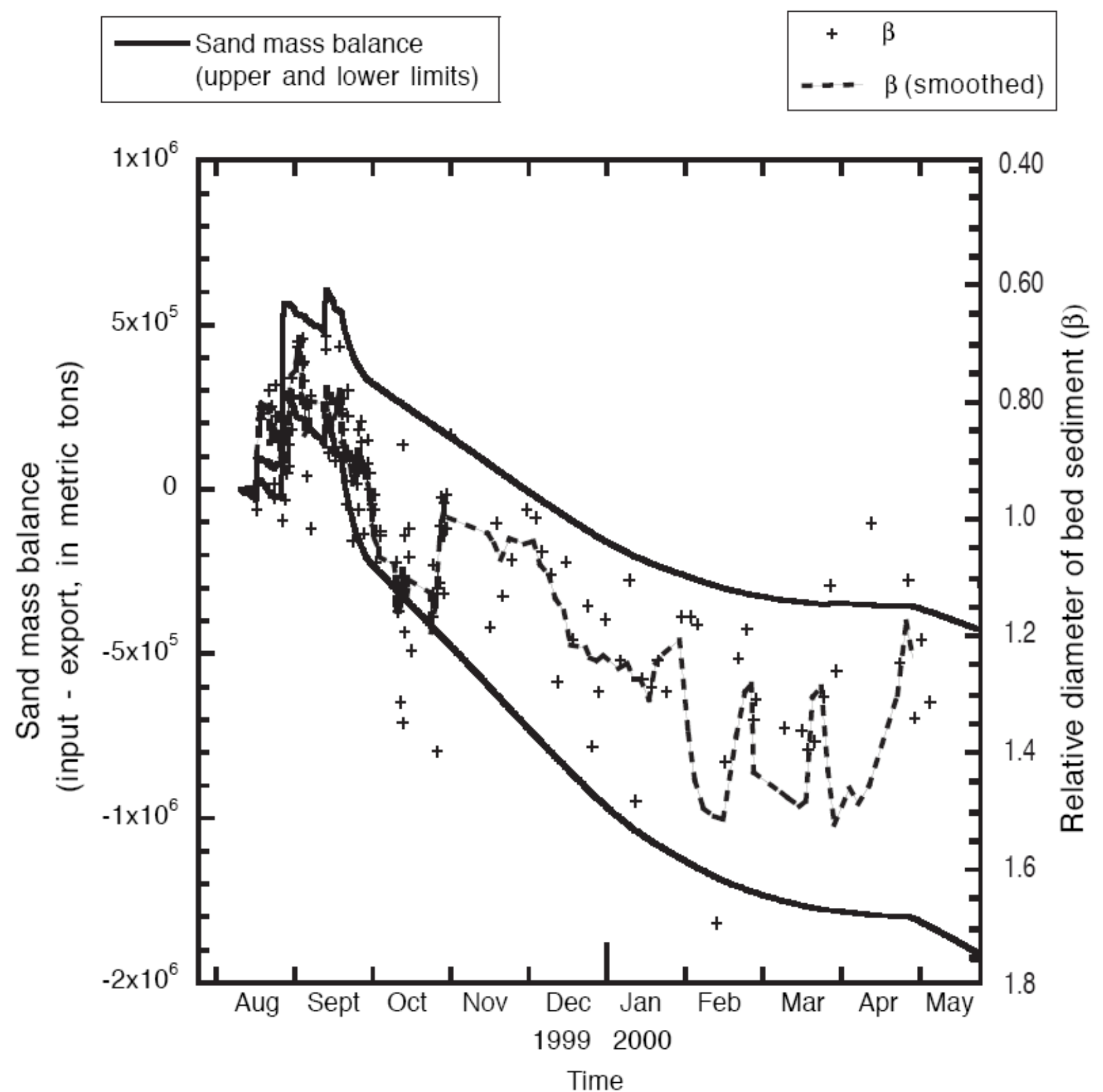

Figure 23. Comparison of the sand budget and $\beta$ at the Grand Canyon gaging station during Period 1. $\beta$ values were calculated relative to the mean for data from 1944-2000. 
A.

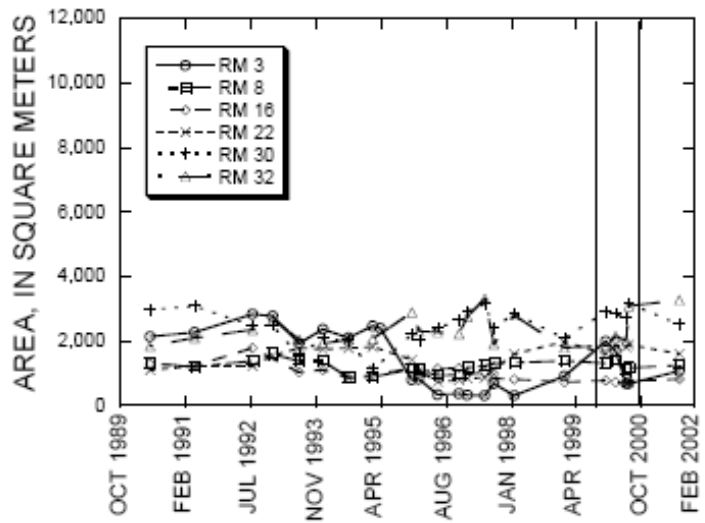

c.

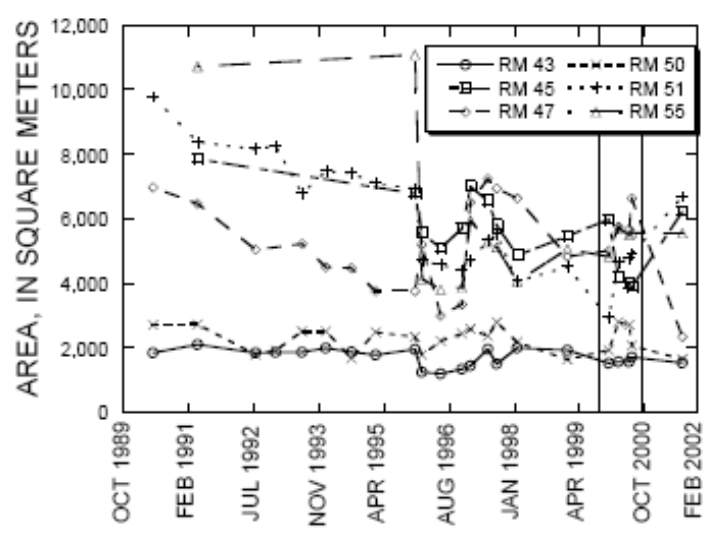

E.

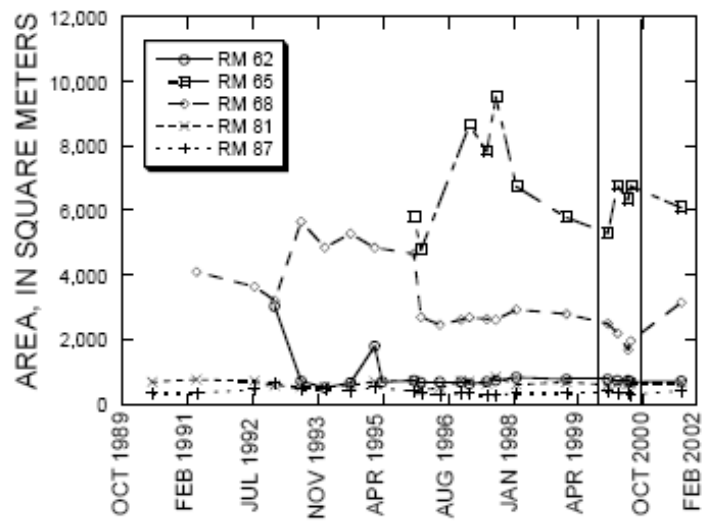

$B$.

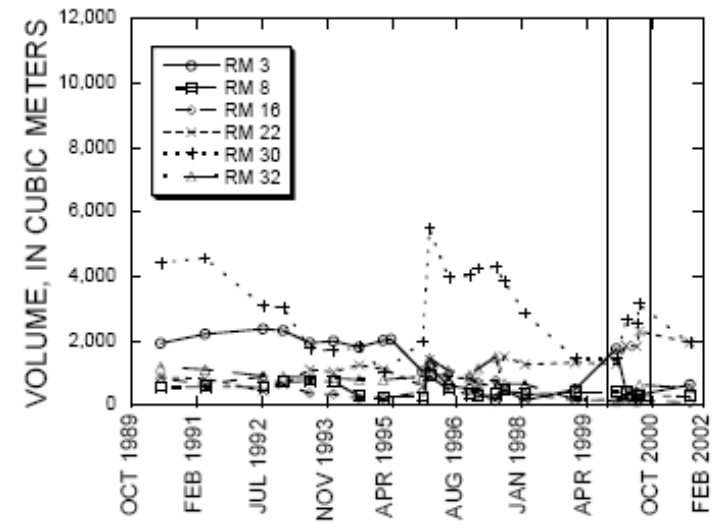

D.

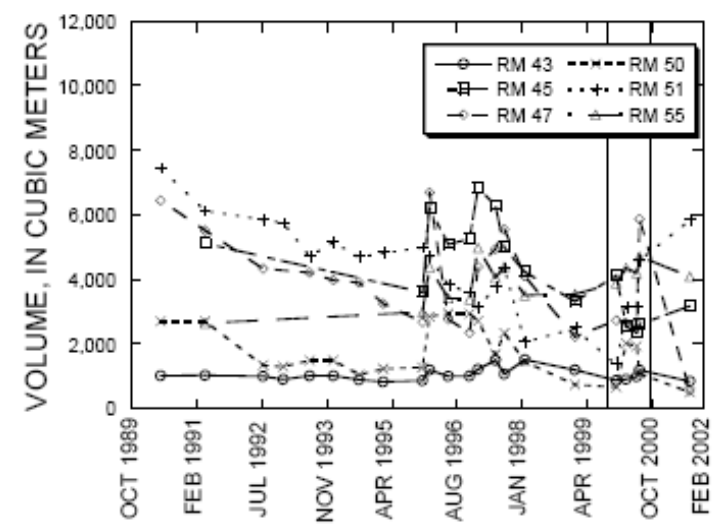

F.

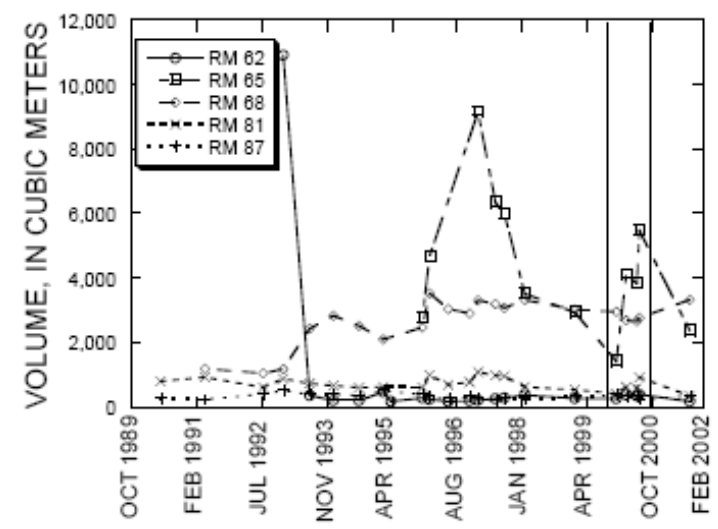

Figure 24. Graphs showing temporal changes in the area and volume of fine sediment between the stages associated with discharges of $227 \mathrm{~m}^{3} / \mathrm{s}$ and $708 \mathrm{~m}^{3} / \mathrm{s}$ at 17 study sites in Marble and upper Grand Canyons. Vertical bars indicate the period of the LSSF experiment. (A) Fine-sediment area in sites in upper Marble Canyon. (B) Fine-sediment volume in sites in upper Marble Canyon. (C) Finesediment area in sites in lower Marble Canyon. (D) Fine-sediment volume in sites in lower Marble Canyon. (E) Fine-sediment area in sites in upper Grand Canyon. (F) Fine-sediment volume in sites in upper Grand Canyon. 
A.

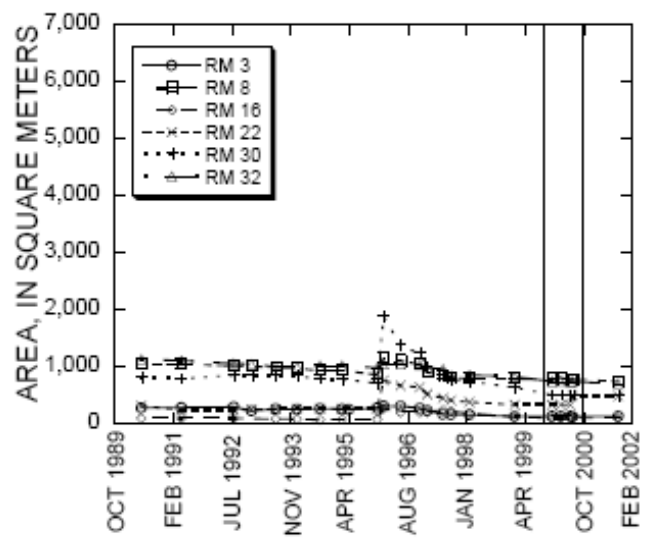

C.

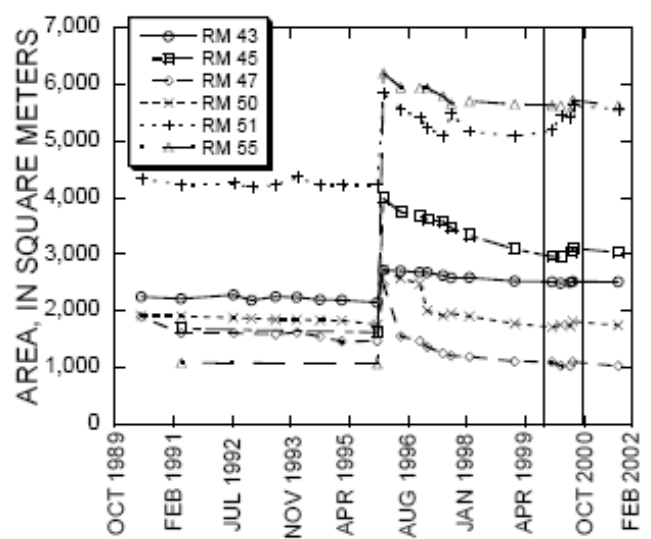

E.

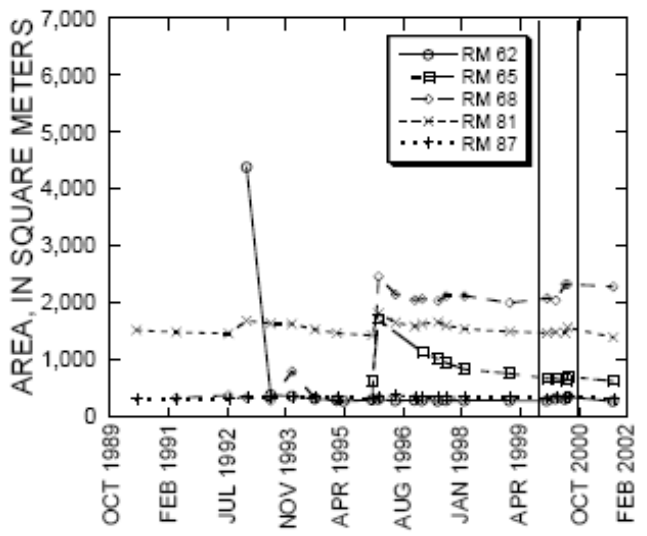

B.

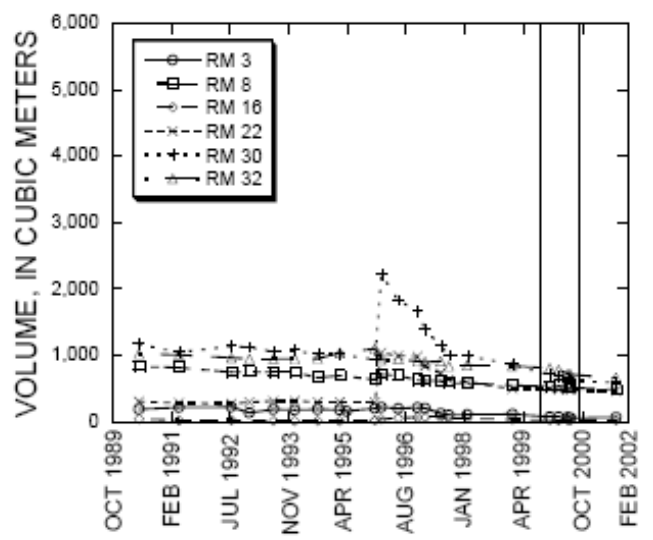

D.

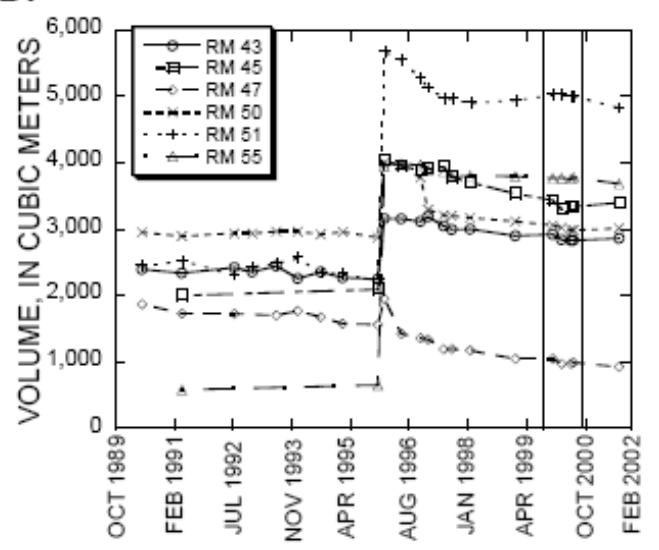

$F$.

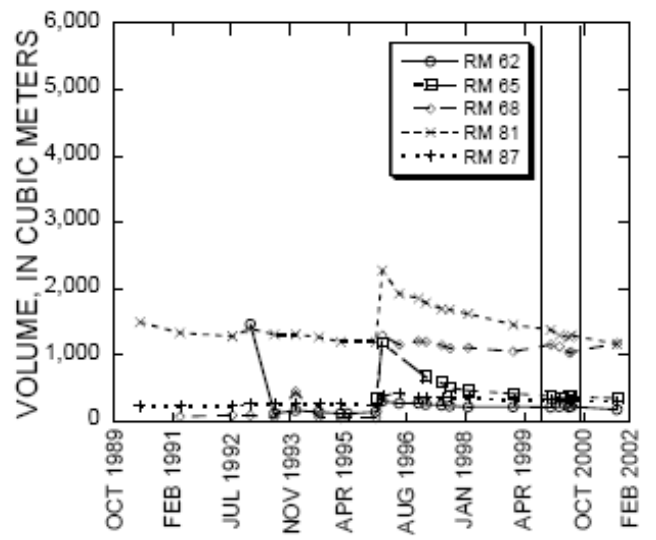

Figure 25. Graphs showing temporal changes in the area and volume of fine sediment above the stage associated with the discharge of $708 \mathrm{~m}^{3} / \mathrm{s}$ at 17 study sites in Marble and upper Grand Canyons. Vertical bars indicate the period of the LSSF experiment. (A) Fine-sediment area in sites in upper Marble Canyon. (B) Fine-sediment volume in sites in upper Marble Canyon. (C) Fine-sediment area in sites in lower Marble Canyon. (D) Fine-sediment volume in sites in lower Marble Canyon. (E) Fine-sediment area in sites in upper Grand Canyon. (F) Fine-sediment volume in sites in upper Grand Canyon. 

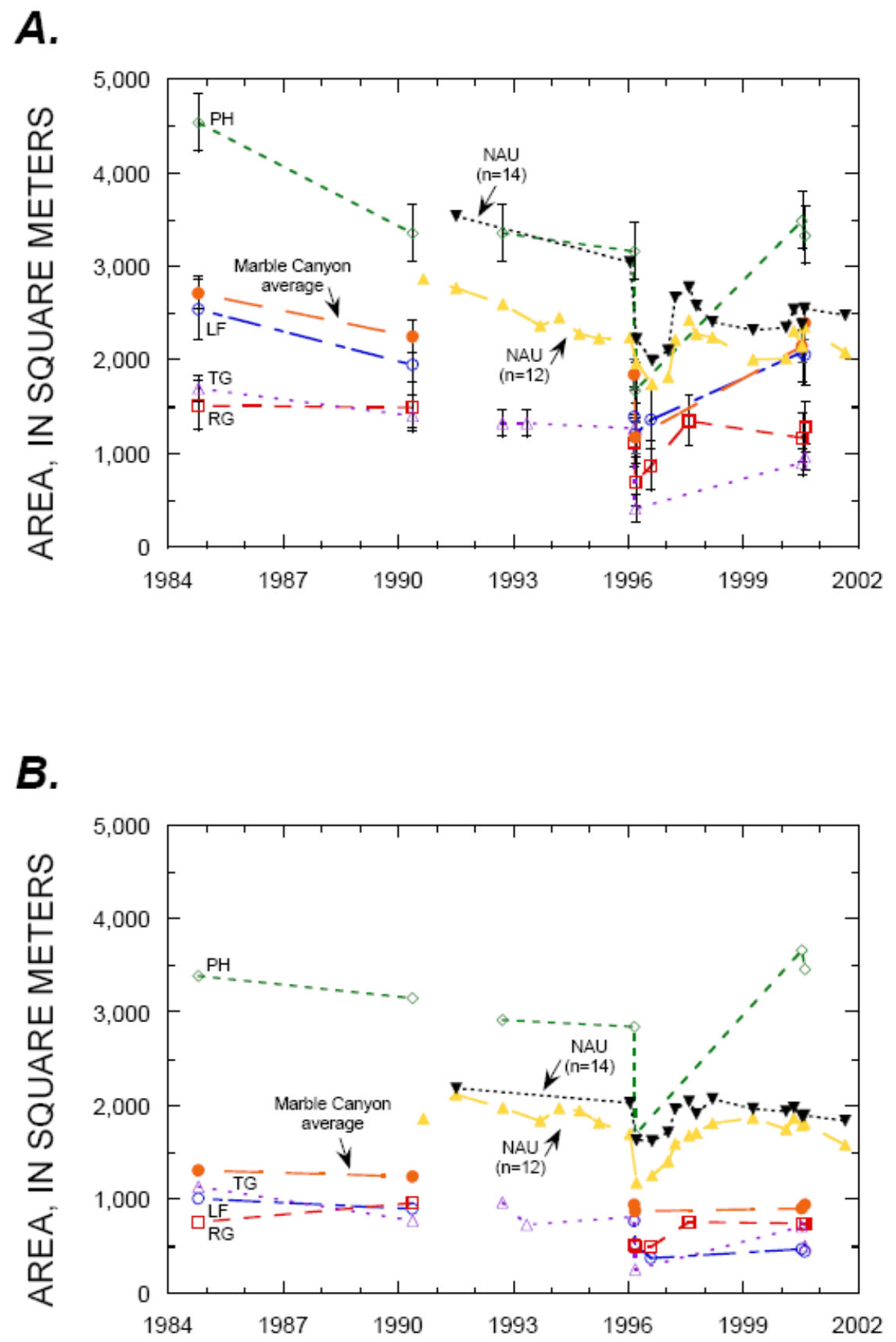

Figure 26. Graphs showing the temporal sequence of the mean (A) and median (B) area of midelevation fine-sediment deposits in larger eddies (i.e., in only the eddies larger than 1,000 $\mathrm{m}^{2}$ ) between 1984 and 2001. LF is Lees Ferry study reach. RG is Redwall Gorge study reach. PH is Point Hansbrough study reach. TG is Tapeats Gorge study reach. MC is Marble Canyon aggregate. NAU $(n=12)$ and NAU $(n=14)$ are two samples of the population of eddy sandbars in Marble Canyon surveyed by Northern Arizona University (NAU). 
$A$.

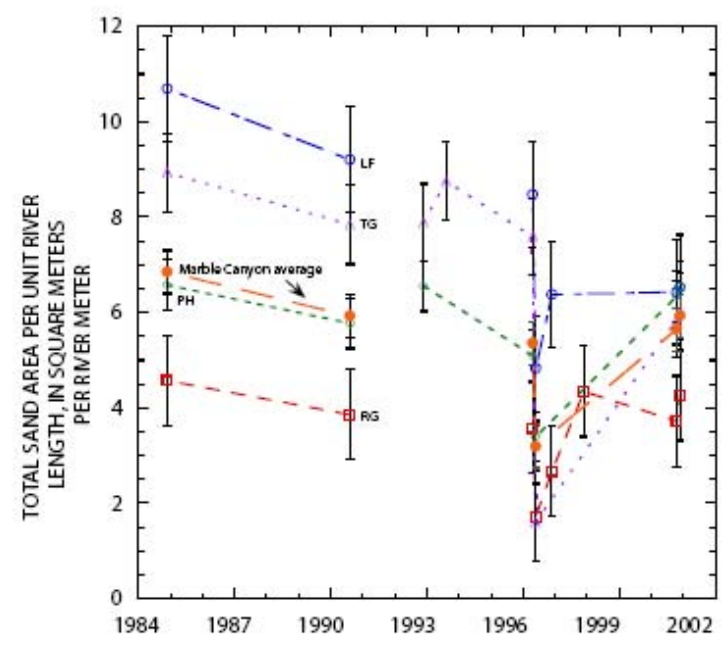

$B$.

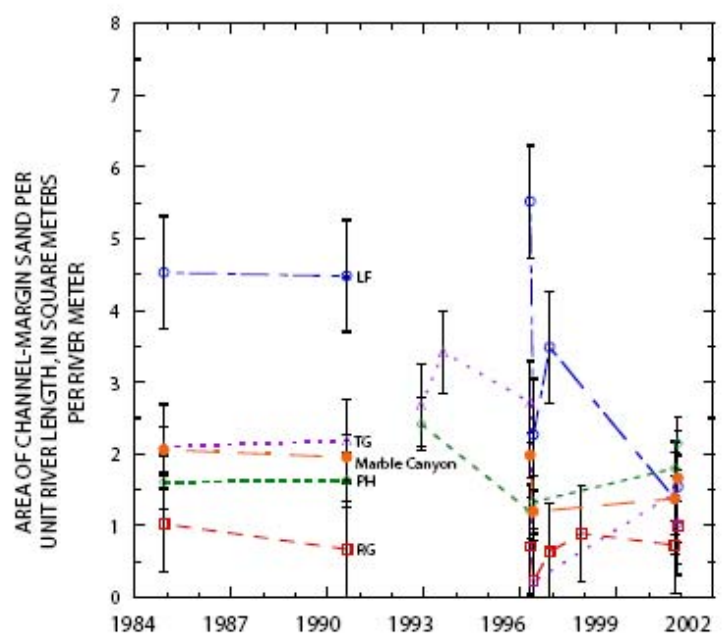

C.

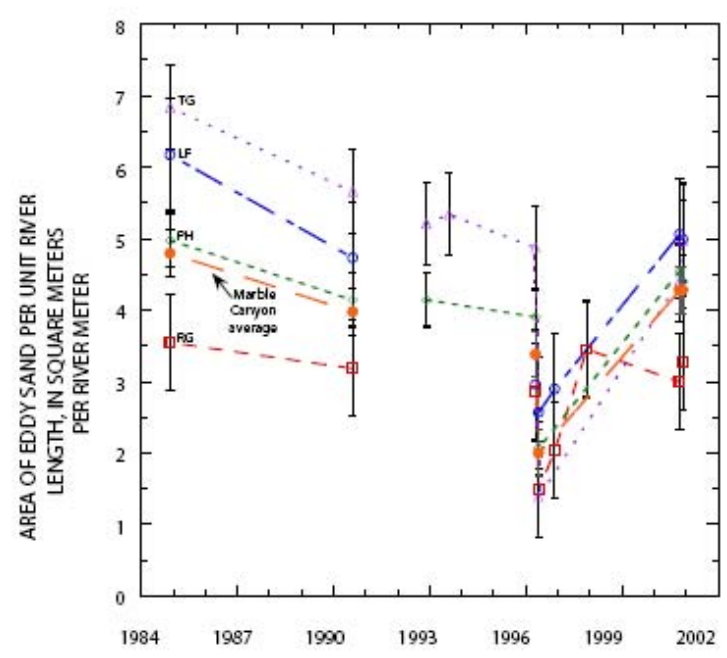

Figure 27. Graphs showing the temporal sequence of mid-elevation fine-sediment deposits, or the area of fine sediment inundated between the stages associated with discharges of 227 and $708 \mathrm{~m}^{3} / \mathrm{s}$, between 1984 and 2000. (A) The total area of fine sediment per unit river length. (B) The area of channel-margin deposits per unit river length. $(C)$ The area of fine-sediment deposits within larger eddies (i.e., in only the eddies larger than $1,000 \mathrm{~m}^{2}$ ) per unit river length. LF is Lees Ferry study reach. $\mathrm{RG}$ is Redwall Gorge study reach. PH is Point Hansbrough study reach. TG is Tapeats Gorge study reach. $\mathrm{MC}$ is Marble Canyon aggregate. 


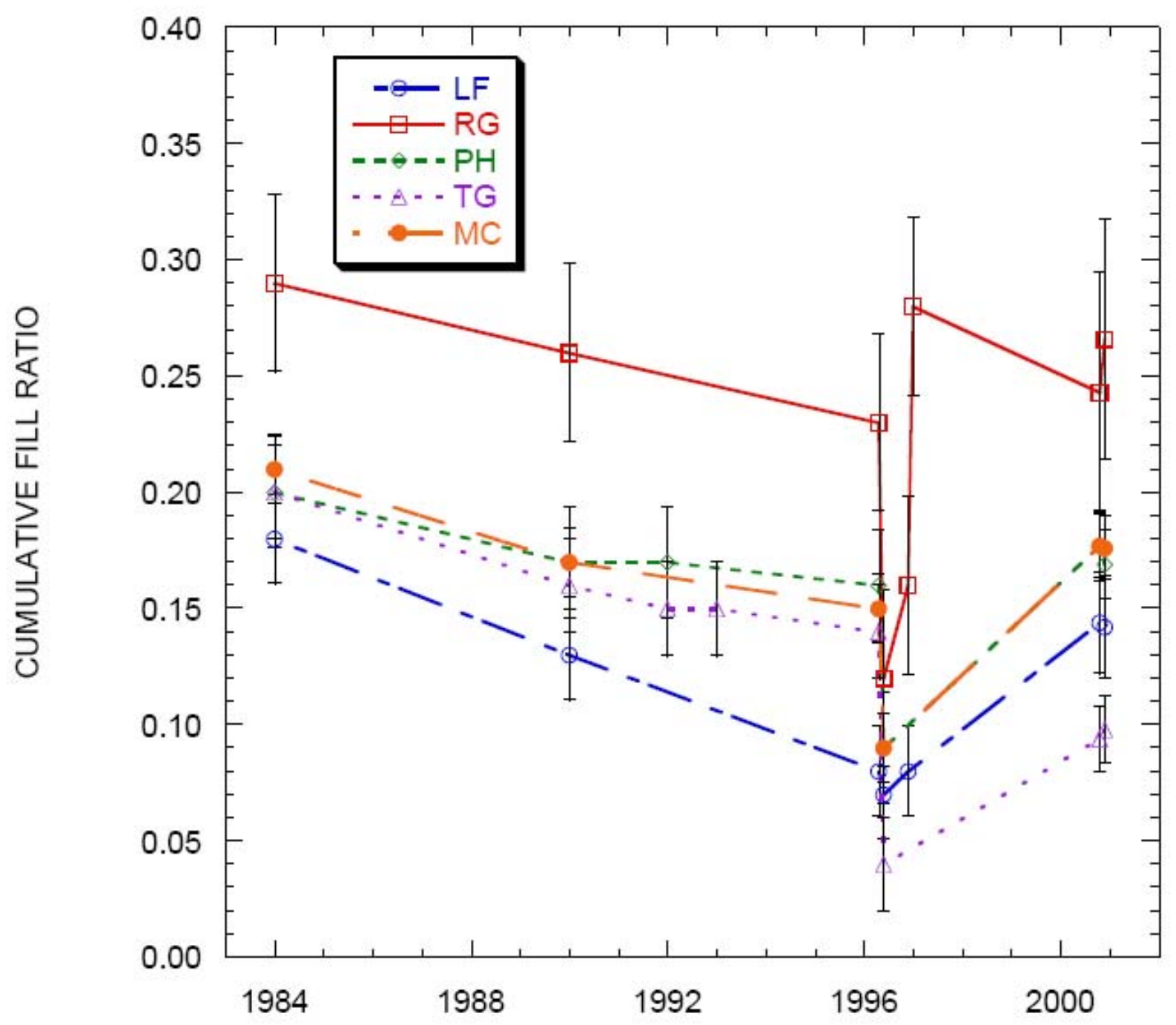

Figure 28. Graph showing the cumulative fill ratio for mid-elevation fine-sediment deposits for four reaches and Marble Canyon, mapped at a common discharge of $227 \mathrm{~m}^{3} / \mathrm{s}$. LF is Lees Ferry study reach. RG is Redwall Gorge study reach. PH is Point Hansbrough study reach. TG is Tapeats Gorge study reach. MC is Marble Canyon aggregate. 
A.

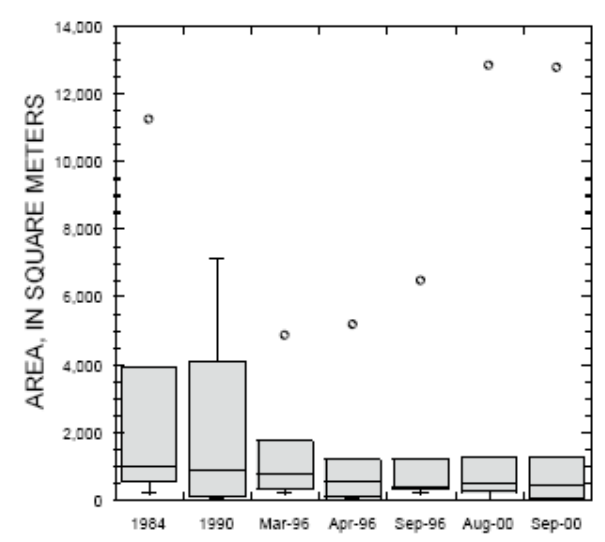

c.

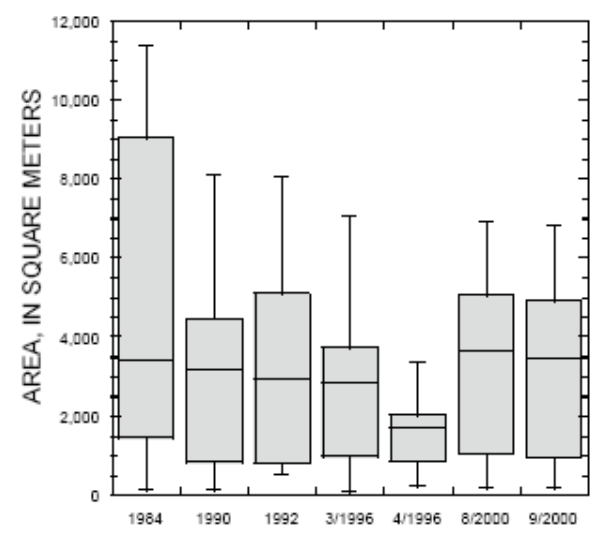

E.

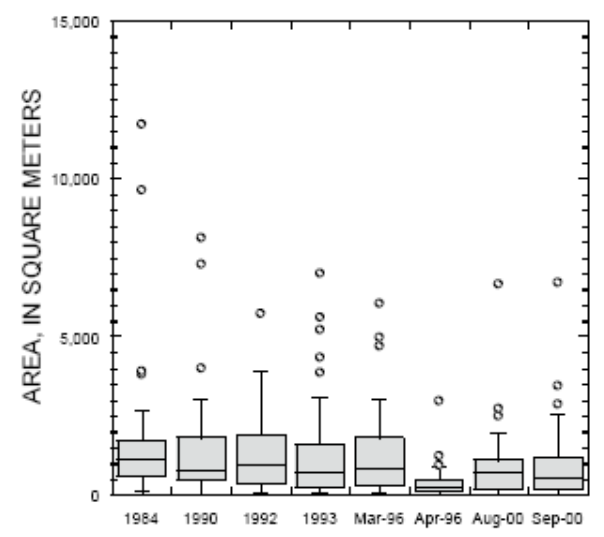

B.

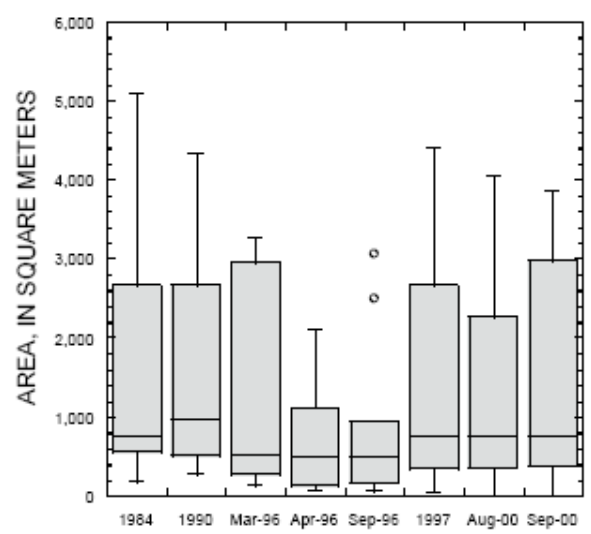

D.

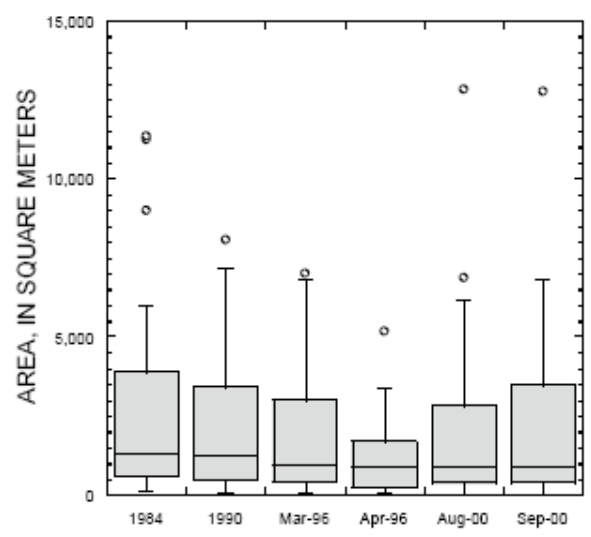

Figure 29. Box-and-whisker plots showing the distribution of areas of mid-elevation fine-sediment deposits in larger eddies (i.e., in only the eddies larger than 1,000 $\mathrm{m}^{2}$ ) in four reaches and Marble Canyon, mapped at a common discharge of $227 \mathrm{~m}^{3} / \mathrm{s}$. (A) Lees Ferry study reach. (B) Redwall Gorge study reach. (C) Point Hansbrough study reach. (D) Marble Canyon aggregate. (E) Tapeats Gorge study reach. 
A.

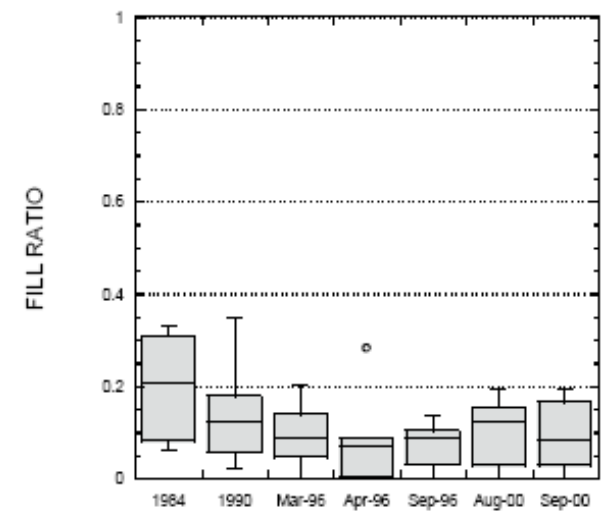

c.

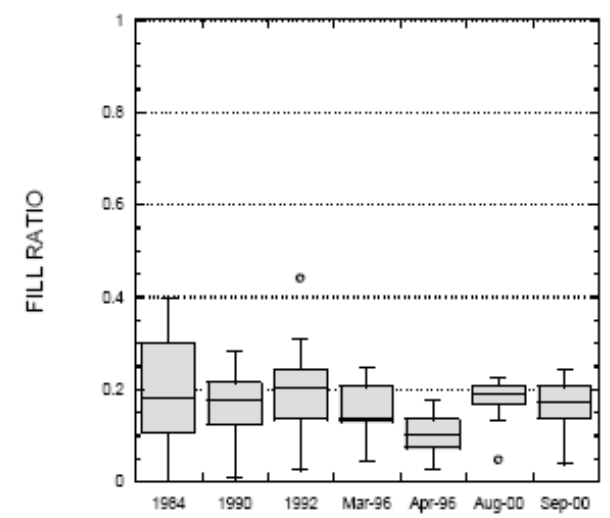

B.

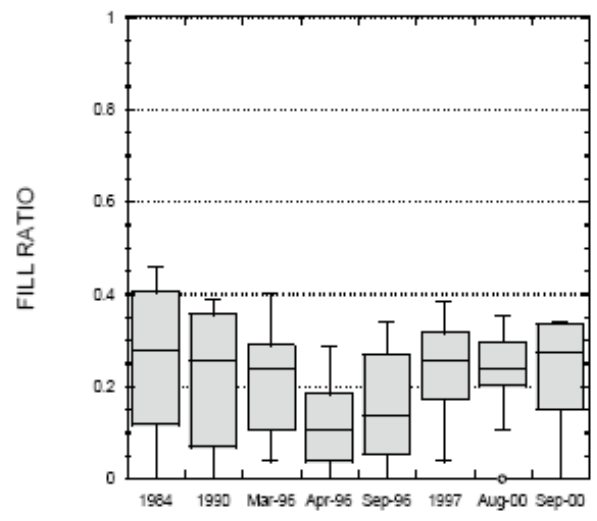

D.

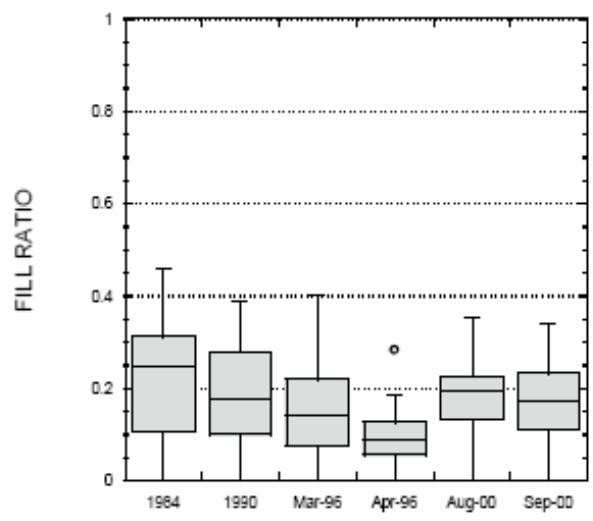

E.

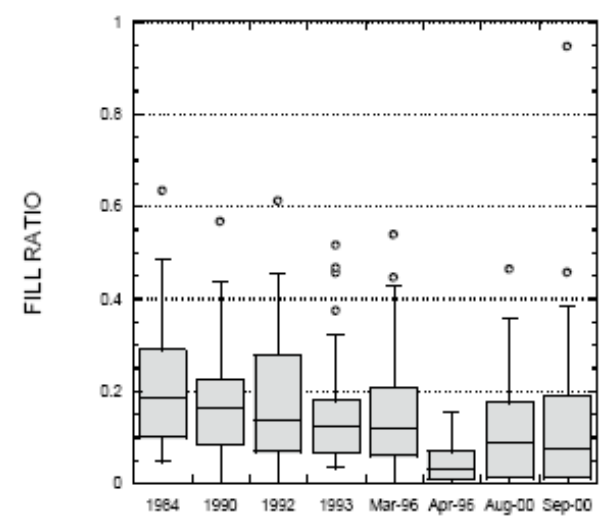

Figure 30. Box-and-whisker plots of the distribution of fill ratios for mid-elevation fine-sediment deposits in larger eddies (i.e., in only the eddies larger than 1,000 $\mathrm{m}^{2}$ ), mapped at a common discharge of $227 \mathrm{~m}^{3} / \mathrm{s}$. (A) Lees Ferry study reach. (B) Redwall Gorge study reach. (C) Point Hansbrough study reach. (D) Marble Canyon aggregate. (E) Tapeats Gorge study reach. 
A.

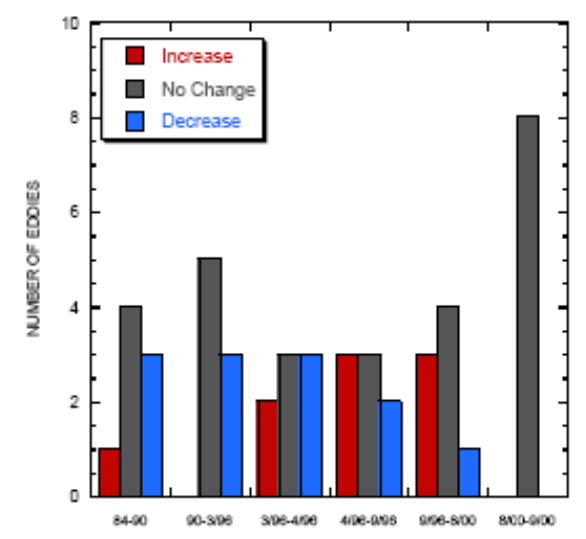

c.

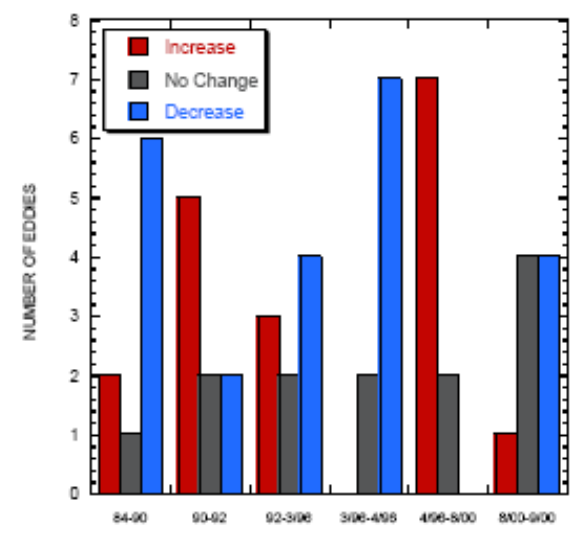

B.

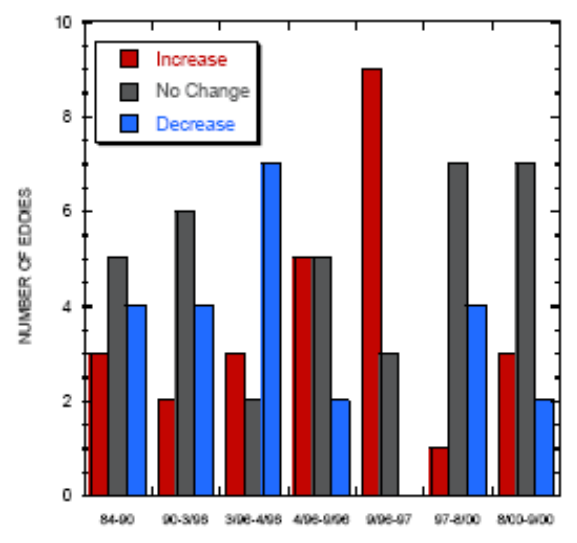

D.

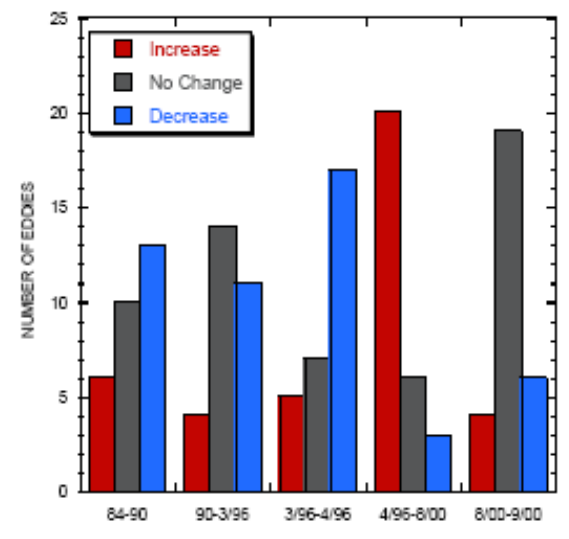

E.

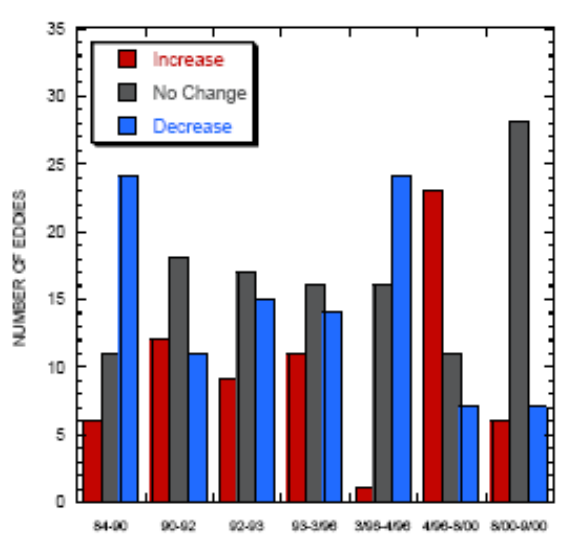

Figure 31. Histograms showing the number of eddies in which the area of low-elevation finesediment deposits increased or decreased by more than $200 \mathrm{~m}^{2}$ in each time interval, mapped at a common discharge of $227 \mathrm{~m}^{3} / \mathrm{s}$. (A) Lees Ferry study reach. (B) Redwall Gorge study reach. (C) Point Hansbrough study reach. (D) Marble Canyon aggregate. (E) Tapeats Gorge study reach. 
A.

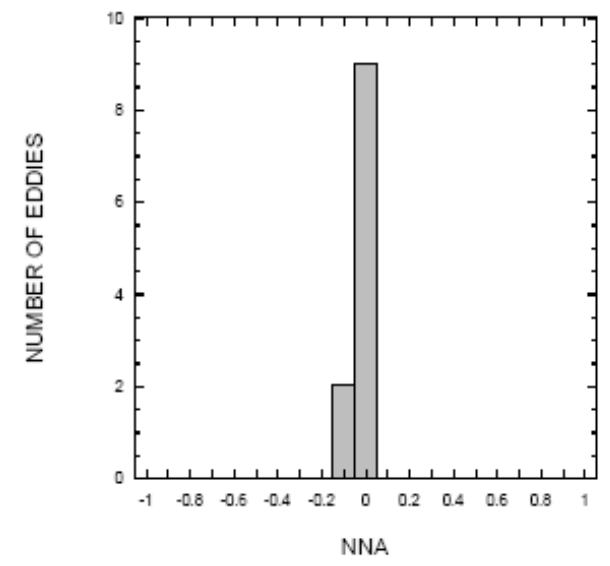

C.

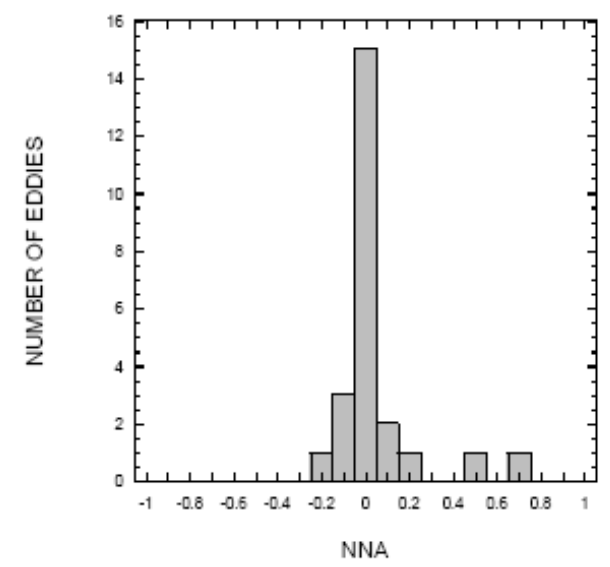

E.

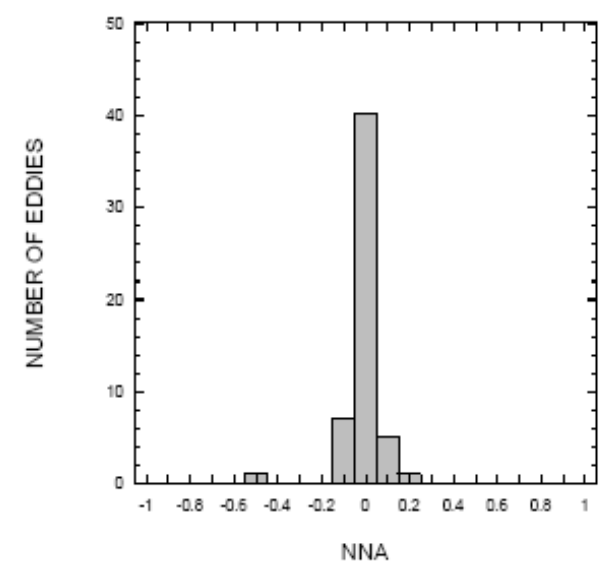

B.

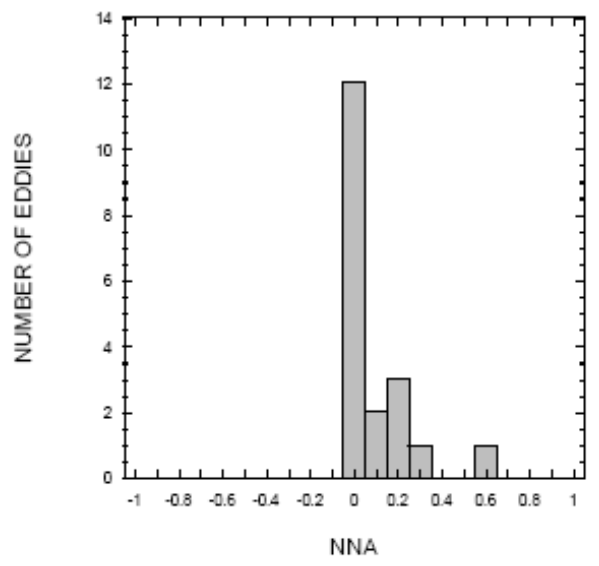

D.

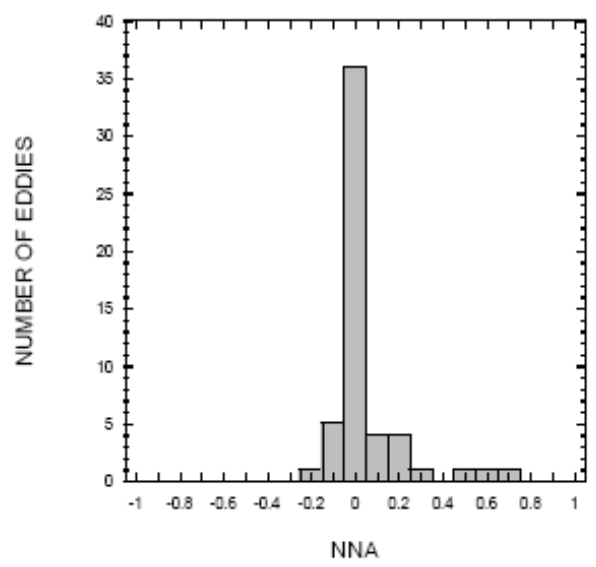

Figure 32. Graphs showing the distribution of net normalized aggradation (NNA) in the four study reaches and Marble Canyon aggregate in response to the September 2000 habitat maintenance flows (HMF). (A) Lees Ferry study reach. (B) Redwall Gorge study reach. (C) Point Hansbrough study reach. (D) Marble Canyon aggregate. (E) Tapeats Gorge study reach. 
A.

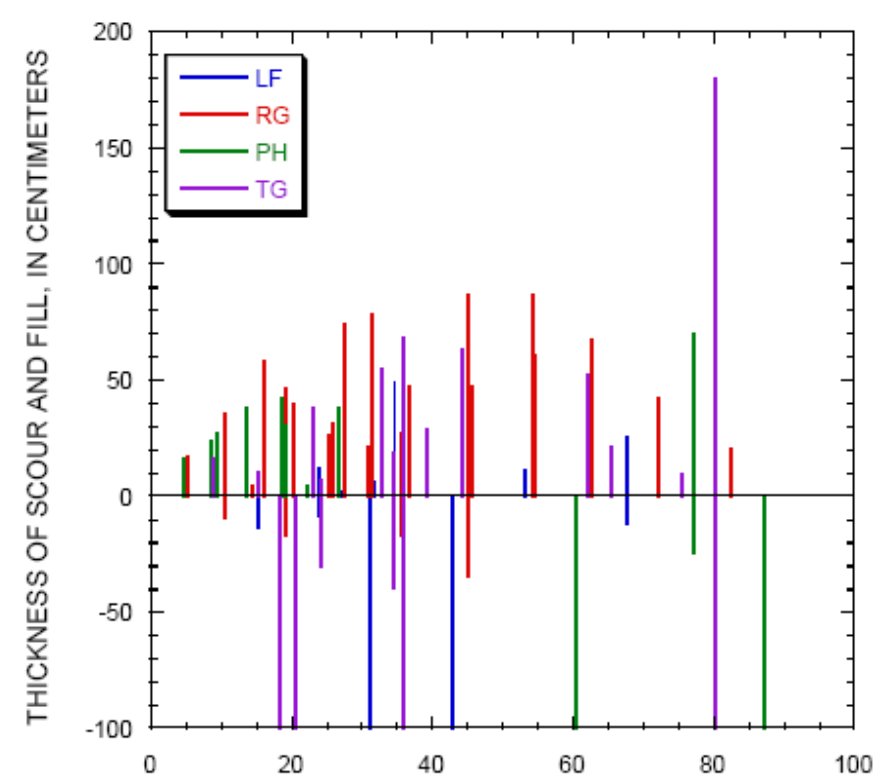

B.

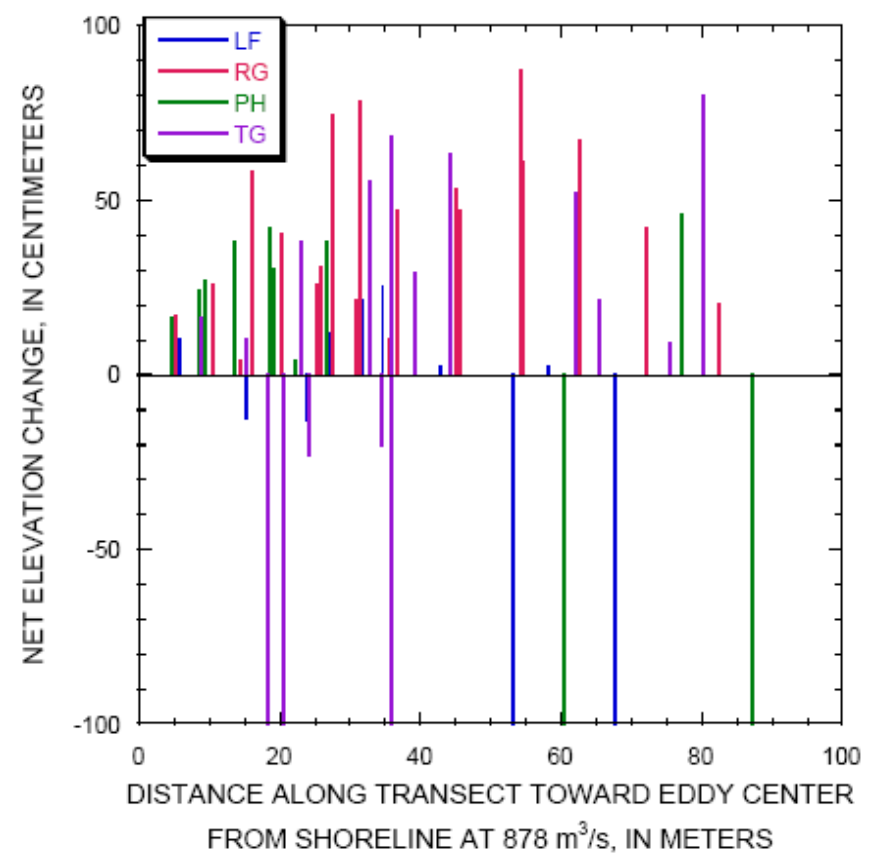

Figure 33. Graphs showing the amount of erosion and deposition at scour-chain sites. (A) Thickness of scour (negative values) and fill (positive values) that occurred at a total of 67 scourchain sites during the September 2000 habitat maintenance flows (HMF). (B) Graph showing the net elevation change at each scour-chain site during the September 2000 HMF. LF is Lees Ferry study reach. RG is Redwall Gorge study reach. PH is Point Hansbrough study reach. TG is Tapeats Gorge study reach. MC is Marble Canyon aggregate. 


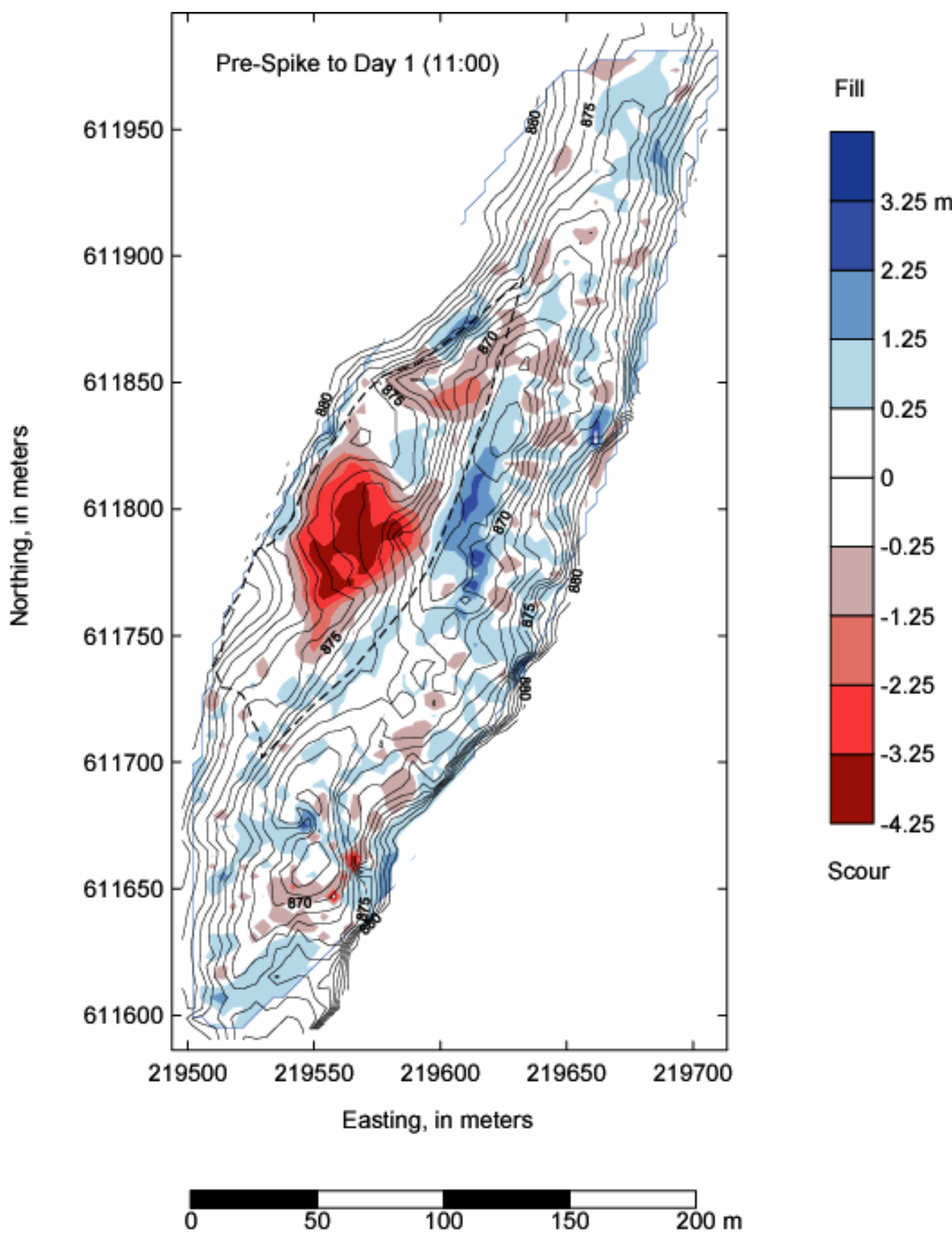

Figure 34. Map showing erosion and deposition at the river mile 30.7 study site within the first day of the September 2000 habitat maintenance flows (HMF). Contours represent topography at the beginning of the HMF; contour interval is $1 \mathrm{~m}$. Dashed outline is the eddy boundary used in finesediment volume calculations. Flow in the main channel (right side of map) is from top to bottom. 
A.

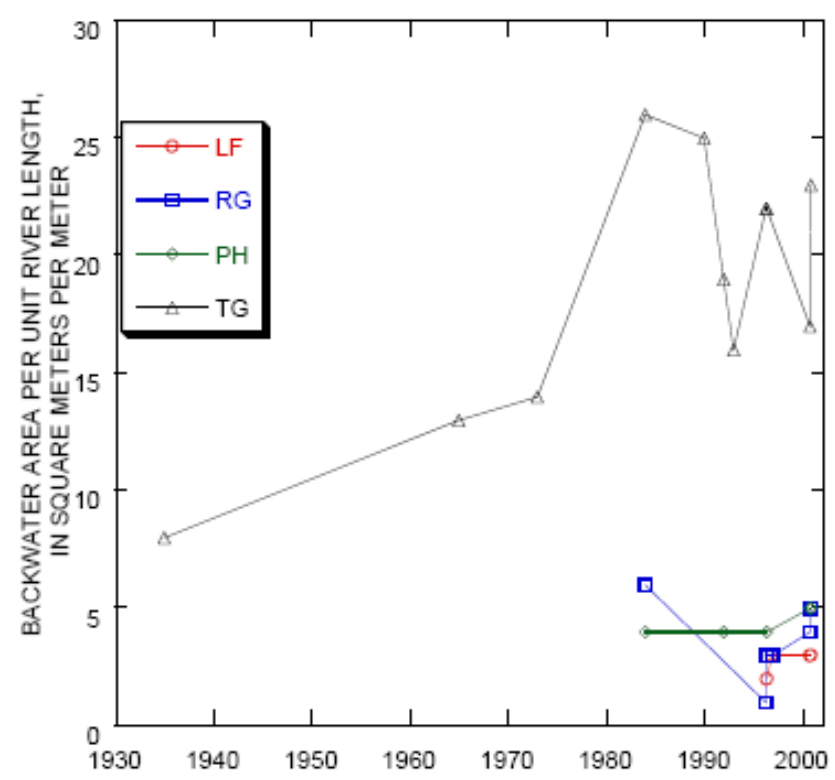

B.

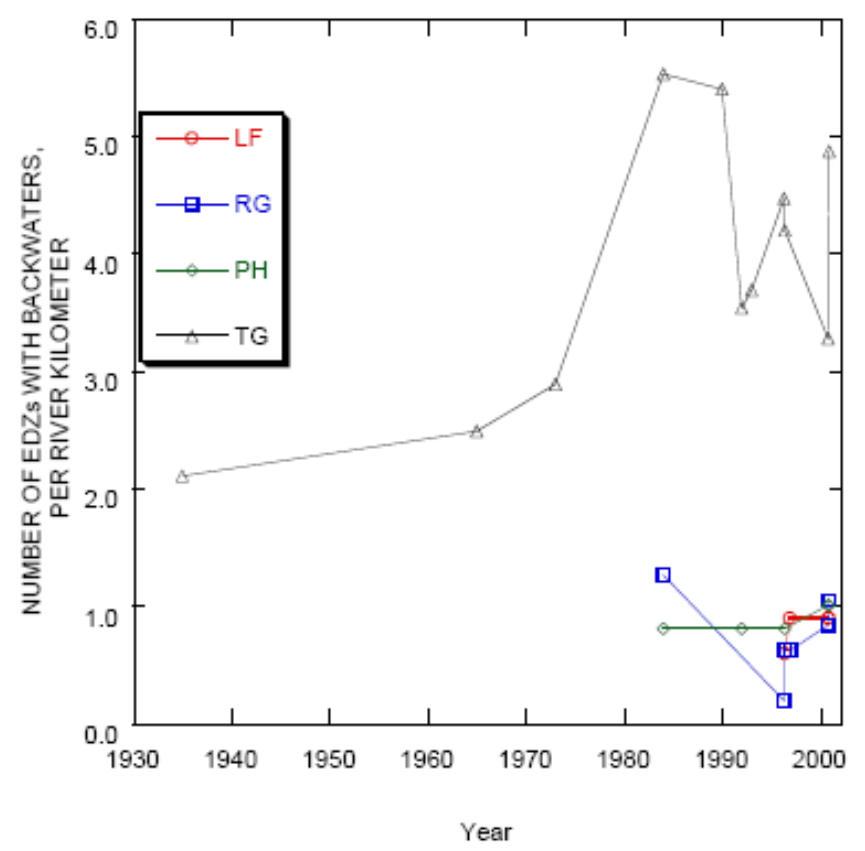

Figure 35. Time series of backwater area (A) and the number of eddies with backwaters (B). LF is Lees Ferry study reach. RG is Redwall Gorge study reach. PH is Point Hansbrough study reach. TG is Tapeats Gorge study reach. 


\section{Tables}

Table 1. Study site locations and geographic place names of the 19 fan-eddy complexes surveyed in March, June, August, and September 2000. (Note: This table uses the terms separation and reattachment sandbars; however, for simplicity, these terms are not used elsewhere in the text. For definitions, please see Schmidt (1990) or Schmidt and Graf (1990).)

\begin{tabular}{|c|c|c|}
\hline $\begin{array}{c}\text { Site location } \\
\text { (river mile) }\end{array}$ & $\begin{array}{l}\text { Geographic } \\
\text { place name }\end{array}$ & $\begin{array}{c}\text { Type of } \\
\text { eddy sandbar }\end{array}$ \\
\hline-6 & -6 Mile & reattachment sandbar \\
\hline 3 & Above Cathedral & reattachment sandbar \\
\hline 8 & Jackass Canyon & separation sandbar \\
\hline 16 & Hot Na Na Wash & separation sandbar \\
\hline 22 & 22-Mile Wash & reattachment sandbar \\
\hline 30 & Fence Fault & reattachment sandbar \\
\hline 32 & South Canyon & undifferentiated eddy sandbar \\
\hline 35 & Nautiloid Canyon & both separation and reattachment sandbars \\
\hline 43 & Anassazi Bridge & undifferentiated eddy sandbar \\
\hline 45 & Eminence & both separation and reattachment sandbars \\
\hline 47 & Saddle Canyon & reattachment sandbar \\
\hline 50 & 50-Mile & both separation and reattachment sandbars \\
\hline 51 & 51-Mile & reattachment sandbar \\
\hline 55 & 55-Mile & reattachment sandbar \\
\hline 62 & Crash Canyon & reattachment sandbar \\
\hline 65 & Carbon Creek & both separation and reattachment sandbars \\
\hline 68 & Tanner Canyon & undifferentiated eddy sandbar \\
\hline 81 & Grapevine & undifferentiated eddy sandbar \\
\hline 87 & Cremation & separation sandbar \\
\hline
\end{tabular}


Table 2. Descriptions of the four study reaches included in photogeologic mapping based on two sets of aerial photographs acquired before and after the September 2000 habitat maintenance flows (HMF).

\begin{tabular}{|l|c|c|c|c|}
\hline \multicolumn{1}{|c|}{ Reach } & Lees Ferry & Redwall Gorge & Point Hansbrough & Tapeats Gorge \\
\hline Reach length $(\mathrm{km})$ & 3.3 & 4.7 & 4.9 & 8.5 \\
Mean size of eddies, in $\mathrm{m}^{2}$ & 10,718 & 3,064 & 7,011 & 6,676 \\
Number of eddies & 11 & 20 & 26 & 54 \\
Number of eddies larger than $1,000 \mathrm{~m}^{2}$ & 8 & 12 & 9 & 41 \\
Number of NAU survey sites in reach & 1 & 2 & 2 & 2 \\
Number of scour-chain transects & 4 & 5 & 4 & 5 \\
\hline
\end{tabular}

Table 3. Error matrix of the agreement between areas surveyed by Northern Arizona University (NAU) and estimated by Utah State University (USU).

\begin{tabular}{ll|c|c|c|} 
& \multicolumn{3}{c}{ Area, in square meters, surveyed by NAU } \\
\cline { 3 - 5 } & & Erosion & No Change & Deposition \\
\cline { 3 - 5 } Area, in square meters, & Erosion & 1,994 & 1,213 & 95 \\
\cline { 3 - 5 } mapped by USU & No change & 1,166 & 9,141 & 4,940 \\
\cline { 3 - 5 } & Deposition & 17 & 872 & 3,673 \\
\cline { 3 - 5 } & &
\end{tabular}

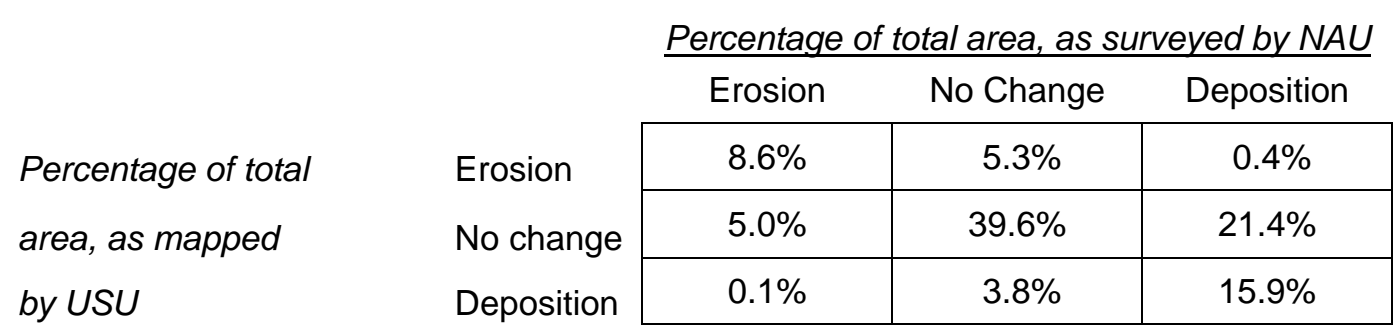

Overall accuracy $=64.1 \%$ 
Table 4. Data from scour chains installed in August 2000 and recovered in September 2000. Chains were not recovered at sites noted below as scoured.

\begin{tabular}{|c|c|c|c|c|c|}
\hline Reach & Location \& type & Chains & Deposition (cm) & Erosion $(\mathrm{cm})$ & Net change (cm) \\
\hline$\overline{\text { Lees }}$ & Paria Eddy & 1--1--1 & 0 & SCOURED & -100 \\
\hline \multirow[t]{4}{*}{ Ferry } & separation sandbar & $1--1--2$ & 0 & SCOURED & -100 \\
\hline & & $1--1--3$ & 2 & 0 & 2 \\
\hline & & $1--1--4$ & 2 & 0 & 2 \\
\hline & & $1--1--5$ & 2 & 0 & 2 \\
\hline Lees & River right below bend & $1--2--1$ & 2 & 0 & 2 \\
\hline \multirow[t]{3}{*}{ Ferry } & channel margin & $1--2--2$ & 1.5 & 0 & 1.5 \\
\hline & & $1--2--3$ & 6 & 0 & 6 \\
\hline & & $1--2--4$ & 12 & -8 & 4 \\
\hline Lees & River left between & $1--3-1$ & 49 & -28 & 21 \\
\hline \multirow[t]{3}{*}{ Ferry } & debris fan & $1--3--2$ & 12 & 0 & 12 \\
\hline & undifferentiated eddy & $1--3--3$ & 0 & -13 & -13 \\
\hline & sandbar & $1--3--4$ & 0 & 0 & 0 \\
\hline Lees & River left below & $1--4--1$ & 25 & 0 & 25 \\
\hline \multirow[t]{3}{*}{ Ferry } & debris fan & $1--4--2$ & 4 & -11 & -7 \\
\hline & reattachment sandbar & $1--4--3$ & 0 & -12 & -12 \\
\hline & & $1--4--4$ & 10 & 0 & 10 \\
\hline Lees & Silver Grotto & $2--1--1$ & 20 & 0 & 20 \\
\hline \multirow[t]{4}{*}{ Ferry } & separation sandbar & $2--1--2$ & 42 & 0 & 42 \\
\hline & & $2--1--3$ & 67 & 0 & 67 \\
\hline & & $2--1--4$ & 87 & 0 & 87 \\
\hline & & $2--1--5$ & 87 & -34 & 53 \\
\hline Redwall & River right downstream & $2--2--1--1$ & 21 & 0 & 21 \\
\hline \multirow[t]{3}{*}{ Gorge } & from Silver Grotto & $2--2--1--2$ & 31 & 0 & 31 \\
\hline & undifferentiated eddy & $2--2--1--3$ & 40 & 0 & 40 \\
\hline & sandbar & $2--2--1--4$ & 35 & -9 & 26 \\
\hline Redwall & River right downstream & $2--2--2--1$ & 47 & 0 & 47 \\
\hline \multirow[t]{3}{*}{ Gorge } & from Silver Grotto & $2--2--2--2$ & 78 & 0 & 78 \\
\hline & undifferentiated eddy & $2--2--2--3$ & 74 & 0 & 74 \\
\hline & sandbar & $2--2--2--4$ & 46 & -17 & 29 \\
\hline Redwall & 30-mile & $2--3--1$ & 61 & 0 & 61 \\
\hline \multirow[t]{4}{*}{ Gorge } & reattachment sandbar & $2--3--2$ & 47 & 0 & 47 \\
\hline & & $2--3--3$ & 27 & -17 & 10 \\
\hline & & $2--3--4$ & 26 & 0 & 26 \\
\hline & & $2--3--5$ & 58 & 0 & 58 \\
\hline Redwall & South Canyon & $2--4--1$ & 4 & 0 & 4 \\
\hline \multirow[t]{2}{*}{ Gorge } & separation sandbar & $2--4--2$ & 6 & 0 & 6 \\
\hline & & $2--4--3$ & 17 & 0 & 17 \\
\hline Point & 43-Mile & $3--1--1$ & 30 & 0 & 30 \\
\hline Hans- & reattachment sandbar & $3--1--2$ & 38 & 0 & 38 \\
\hline \multirow{2}{*}{ brough } & & $3--1--3$ & 24 & 0 & 24 \\
\hline & & $3--1--4$ & 16 & 0 & 16 \\
\hline
\end{tabular}


Table 4. Data from scour chains installed in August 2000 and recovered in September 2000. Chains were not recovered at sites noted below as scoured.-Continued

\begin{tabular}{llrrrr}
\hline Point & Eminence & $3--2--1--1$ & 0 & SCOURED & -100 \\
Hans- & reattachment sandbar & $3--2--1--2$ & 70 & -24 & 46 \\
brough & & $3--2--1--3$ & 0 & SCOURED & -100 \\
Point & Eminence & $3--2--2-1$ & 6 & 0 & 6 \\
Hans- & reattachment sandbar & $3--2--2--2$ & 2 & 0 & 2 \\
brough & & $3--2--2--3$ & 4 & 0 & 4 \\
\hline Point & Eminence & $3--2--3-1$ & 38 & 0 & 38 \\
Hans- & separation sandbar & $3--2--3--2$ & 42 & 0 & 42 \\
brough & & $3--2--3--3$ & 27 & 0 & 27 \\
Tapeats & 60-mile & $4--1-1$ & 9 & 0 & 9 \\
Gorge & reattachment sandbar & $4--1--2$ & 21 & 0 & 21 \\
& & $4--1--3$ & 19 & -39 & -20 \\
& & $4--1--4$ & 16 & 0 & 16 \\
\hline Tapeats & River right below 60-mi & $4--2--1$ & 29 & 0 & 29 \\
Gorge & reattachment sandbar & $4--2--2$ & 7 & -30 & -100 \\
Tapeats & River left abv. LCR & $4--3--1$ & 0 & SCOURED & -100 \\
Gorge & reattachment sandbar & $4--3--2$ & 0 & SCOURED & 63 \\
Tapeats & River left Tapeats Gorge & $4--4--1$ & 63 & 0 & 55 \\
Gorge & reattachment sandbar & $4--4--2$ & 55 & 0 & 38 \\
& & $4--4--3$ & 38 & 0 & 10 \\
\hline Tapeats & Carbon Creek & $4--4--4$ & 10 & 0 & 80 \\
Gorge & reattachment sandbar & $4--5-1$ & 180 & SCOURED & 52 \\
& & $4--5--2$ & 52 & 0 & 68 \\
& & $4--5--3$ & 68 & 0 & -100 \\
\hline
\end{tabular}


Table 5. Change in sediment mass during each of the five periods. Demonstrable erosion is shown in bold-face type, demonstrable accumulation is shown in normal type, no demonstrable change is shown in italics.

\begin{tabular}{|l|l|l|l|}
\hline \multicolumn{1}{|c|}{ Period } & \multicolumn{2}{c|}{$\begin{array}{c}\text { Change in sand mass } \\
\text { (metric tons) }\end{array}$} & \multicolumn{2}{c|}{$\begin{array}{c}\text { Change in silt and clay mass } \\
\text { (metric tons) }\end{array}$} \\
\hline & \multicolumn{1}{|c|}{ Marble Canyon } & Upper Grand Canyon & \multicolumn{1}{c|}{ Marble Canyon } \\
\hline Period 1 & $\mathbf{- 9 2 0 , 0 0 0 \pm 4 9 0 , 0 0 0}$ & $-520,000 \pm 680,000$ & $-410,000 \pm 690,000$ \\
\hline Period 2 (May HMF) & $\mathbf{- 3 4 0 , 0 0 0} \pm \mathbf{6 5 , 0 0 0}$ & $+46,000 \pm 94,000$ & $\mathbf{- 5 9 , 0 0 0} \pm \mathbf{1 2 , 0 0 0}$ \\
\hline Period 3 & $\mathbf{- 1 4 0 , 0 0 0 \pm \mathbf { 2 5 , 0 0 0 }}$ & $-19,000 \pm 42,000$ & $\mathbf{- 1 8 , 0 0 0 \pm \mathbf { 3 , 5 0 0 }}$ \\
\hline Period 4 (low, steady flows) & $+31,000 \pm 18,000$ & $+8,100 \pm 7,900$ & $-9,000 \pm 32,000$ \\
\hline Period 5 (Sept HMF) & $\mathbf{- 2 2 0 , 0 0 0} \pm \mathbf{4 5 , 0 0 0}$ & $-12,000 \pm 66,000$ & $\mathbf{- 6 5 , 0 0 0} \pm \mathbf{1 2 , 0 0 0}$ \\
\hline
\end{tabular}


Table 6. Bed area (in $\mathrm{m}^{2}$ ) and fraction of bed area (in \%) composed of each bed-texture class before and after the September habitat maintenance flows (HMF) in the three study reaches in Marble Canyon, as determined from side-scan sonar data. The sand and finer-gravel classes are further subdivided between main-channel and eddy environments.

\begin{tabular}{|c|c|c|c|c|c|}
\hline Reach & Bed-texture class & $\begin{array}{l}\text { Pre-HMF } \\
\text { Area }\left(\mathrm{m}^{2}\right) \\
\end{array}$ & $\begin{array}{l}\text { Post-HMF } \\
\text { Area }\left(\mathrm{m}^{2}\right) \\
\end{array}$ & $\begin{array}{c}\text { Pre-HMF } \\
\text { Fraction (\%) }\end{array}$ & $\begin{array}{c}\text { Post-HMF } \\
\text { Fraction (\%) }\end{array}$ \\
\hline \multirow[t]{9}{*}{ Lees Ferry } & Eddy sand & 1,460 & 2,180 & 0.9 & 1.1 \\
\hline & Main-channel sand & 11,440 & 19,720 & 7.0 & 10.4 \\
\hline & Total sand & 12,900 & 21,900 & 7.9 & 11.5 \\
\hline & Eddy finer gravel & 2,170 & 2,850 & 1.3 & 1.5 \\
\hline & Main-channel finer gravel & 111,350 & 126,770 & 68.5 & 66.6 \\
\hline & Total finer gravel & 113,520 & 129,620 & 69.8 & 68.1 \\
\hline & Boulders & 17,490 & 22,440 & 10.8 & 11.7 \\
\hline & Bedrock & 18,750 & 16,490 & 11.5 & 8.7 \\
\hline & Total & 162,660 & 190,450 & 100.0 & 100.0 \\
\hline \multirow{9}{*}{$\begin{array}{l}\text { Redwall } \\
\text { Gorge }\end{array}$} & Eddy sand & 5,800 & 13,120 & 2.1 & 4.7 \\
\hline & Main-channel sand & 41,080 & 76,570 & 14.5 & 27.0 \\
\hline & Total sand & 46,880 & 89,690 & 16.6 & 31.7 \\
\hline & Eddy finer gravel & 5,360 & 2,320 & 1.9 & 0.8 \\
\hline & Main-channel finer gravel & 48,930 & 40,240 & 17.3 & 14.2 \\
\hline & Total finer gravel & 54,290 & 42,560 & 19.2 & 15.0 \\
\hline & Boulders & 117,200 & 58,650 & 41.5 & 20.7 \\
\hline & Bedrock & 64,130 & 92,340 & 22.7 & 32.6 \\
\hline & Total & 282,500 & 283,240 & 100.0 & 100.0 \\
\hline \multirow{9}{*}{$\begin{array}{l}\text { Point } \\
\text { Hansbrough }\end{array}$} & Eddy sand & 5,840 & 4,120 & 6.4 & 7.8 \\
\hline & Main-channel sand & 11,950 & 25,790 & 13.2 & 48.8 \\
\hline & Total sand & 17,790 & 29,910 & 19.6 & 56.6 \\
\hline & Eddy finer gravel & 11,550 & 180 & 12.7 & 0.3 \\
\hline & Main-channel finer gravel & 34,030 & 7,440 & 37.6 & 14.1 \\
\hline & Total finer gravel & 45,580 & 7,620 & 50.3 & 14.4 \\
\hline & Boulders & 3,190 & 2,530 & 3.5 & 4.8 \\
\hline & Bedrock & 24,080 & 12,810 & 26.6 & 24.2 \\
\hline & Total & 90,640 & 52,870 & 100.0 & 100.0 \\
\hline
\end{tabular}


Table 7. Area $\left(\mathrm{m}^{2}\right)$ and volume $\left(\mathrm{m}^{3}\right)$ of fine sediment at each study site, within the high-elevationeddy, mid-elevation-eddy, low-elevation-eddy, and main-channel zones. Data were collected in March, June, August, and September 2000.

\begin{tabular}{|c|c|c|c|c|c|c|c|c|}
\hline \multirow[t]{3}{*}{ Location } & \multicolumn{8}{|c|}{$\begin{array}{c}\text { High-elevation fine sediment } \\
\text { (above stage associated with discharge of } 708 \mathrm{~m}^{3} / \mathrm{s} \text { ) }\end{array}$} \\
\hline & \multicolumn{4}{|c|}{ Area, in square meters } & \multicolumn{4}{|c|}{ Volume, in cubic meters } \\
\hline & March & June & August & September & March & June & August & September \\
\hline Glen Canyon & & & & & & & & \\
\hline River mile -6 & 418 & 524 & 387 & 430 & 353 & 402 & 339 & 379 \\
\hline \multicolumn{9}{|l|}{$\begin{array}{l}\text { Upper Marble } \\
\text { Canyon }\end{array}$} \\
\hline River mile 3 & 132 & 133 & 132 & 134 & 89 & 89 & 85 & 87 \\
\hline River mile 8 & 786 & 804 & 753 & 799 & 547 & 556 & 515 & 553 \\
\hline River mile 16 & 102 & 104 & 106 & 99 & 42 & 34 & 42 & 43 \\
\hline River mile 22 & 334 & 337 & 331 & 509 & 516 & 500 & 529 & 541 \\
\hline River mile 30 & 509 & 500 & 496 & 530 & 724 & 697 & 682 & 702 \\
\hline River mile 32 & 744 & 750 & 728 & 749 & 825 & 795 & 770 & 811 \\
\hline River mile 35 & 766 & 751 & 765 & 778 & 1,106 & 1,074 & 1,106 & 1,096 \\
\hline mean & 482 & 483 & 473 & 514 & 550 & 535 & 533 & 548 \\
\hline standard deviation & 298 & 298 & 289 & 295 & 384 & 373 & 376 & 379 \\
\hline \multicolumn{9}{|l|}{$\begin{array}{l}\text { Lower Marble } \\
\text { Canyon }\end{array}$} \\
\hline River mile 43 & 2,536 & 2,508 & 2,552 & 2,550 & 2,933 & 2,855 & 2,923 & 2,930 \\
\hline River mile 45 & 2,979 & 2,973 & 3,063 & 3,048 & 3,448 & 3,310 & 3,482 & 3,456 \\
\hline River mile 47 & 1,130 & 1,060 & 1,130 & 1,200 & 1,059 & 986 & 1,058 & 1,076 \\
\hline River mile 50 & 1,738 & 1,782 & 1,713 & 1,823 & 3,073 & 3,034 & 3,016 & 3,109 \\
\hline River mile 51 & 5,187 & 5,458 & 5,148 & 5,399 & 5,030 & 5,033 & 5,012 & 5,030 \\
\hline River mile 55 & 5,640 & 5,629 & 5,548 & 5,832 & 3,780 & 3,782 & 3,762 & 3,807 \\
\hline mean & 3,202 & 3,235 & 3,192 & 3,309 & 3,221 & 3,167 & 3,209 & 3,235 \\
\hline standard deviation & 1,834 & 1,903 & 1,802 & 1,899 & 1,297 & 1,323 & 1,294 & 1,294 \\
\hline \multicolumn{9}{|l|}{$\begin{array}{l}\text { Upper Grand } \\
\text { Canyon }\end{array}$} \\
\hline River mile 62 & 291 & 332 & 279 & 333 & 230 & 237 & 225 & 237 \\
\hline River mile 65 & 687 & 684 & 655 & 751 & 400 & 373 & 403 & 407 \\
\hline River mile 68 & 2,154 & 2,099 & 2,441 & 2,179 & 1,215 & 1,179 & 1,130 & 1,226 \\
\hline River mile 81 & 1,486 & 1,499 & 1,473 & 1,580 & 1,395 & 1,314 & 1,364 & 1,424 \\
\hline River mile 87 & 340 & 360 & 331 & 344 & 325 & 341 & 315 & 318 \\
\hline mean & 992 & 995 & 1,036 & 1,037 & 713 & 689 & 687 & 722 \\
\hline standard deviation & 807 & 777 & 919 & 815 & 547 & 514 & 521 & 558 \\
\hline
\end{tabular}


Table 7. Area $\left(\mathrm{m}^{2}\right)$ and volume $\left(\mathrm{m}^{3}\right)$ of fine sediment at each study site, within the high-elevationeddy, mid-elevation-eddy, low-elevation-eddy, and main-channel zones. Data were collected in March, June, August, and September 2000.-Continued

\begin{tabular}{|c|c|c|c|c|c|c|c|c|}
\hline \multirow[t]{3}{*}{ Location } & \multicolumn{8}{|c|}{$\begin{array}{l}\text { Mid-elevation fine sediment } \\
\text { (between stages associated with discharges of } 227 \text { and } 708 \mathrm{~m}^{3} / \mathrm{s} \text { ) }\end{array}$} \\
\hline & \multicolumn{3}{|c|}{ Area, in square meters } & & \multicolumn{3}{|c|}{ Volume, in cubic meters } & \multirow[b]{2}{*}{ Septembe } \\
\hline & March & June & August & September & March & June & August & \\
\hline \multicolumn{9}{|l|}{ Glen Canyon } \\
\hline River mile -6 & 3,472 & 4,055 & 3,798 & 3,127 & 588 & 1373 & 628 & 449 \\
\hline \multicolumn{9}{|l|}{$\begin{array}{l}\text { Upper Marble } \\
\text { Canyon }\end{array}$} \\
\hline River mile 3 & 2,014 & 1,703 & 1,017 & 2,063 & 1,776 & 443 & 1,731 & 1,792 \\
\hline River mile 8 & 1,331 & 1,400 & 1,041 & 1,403 & 438 & 453 & 306 & 452 \\
\hline River mile 16 & 794 & 746 & 749 & 867 & 199 & 197 & 138 & 237 \\
\hline River mile 22 & 1,631 & 1,884 & 1,581 & 1,697 & 1,313 & 1,877 & 1,292 & 1,837 \\
\hline River mile 30 & 2,930 & 2,879 & 2,769 & 3,405 & 1,449 & 2,675 & 1,338 & 2,029 \\
\hline River mile 32 & 1,877 & 2,174 & 1,739 & 2,950 & 154 & 204 & 106 & 667 \\
\hline River mile 35 & 1,184 & 2,050 & 686 & 1,721 & 181 & 621 & 0 & 734 \\
\hline mean & 1,680 & 1,834 & 1,369 & 2,015 & 787 & 924 & 698 & 1,107 \\
\hline standard deviation & 691 & 664 & 733 & 884 & 699 & 963 & 727 & 750 \\
\hline \multicolumn{9}{|l|}{$\begin{array}{l}\text { Lower Marble } \\
\text { Canyon }\end{array}$} \\
\hline River mile 43 & 1,544 & 1,584 & 1,543 & 1,689 & 883 & 921 & 963 & 1,088 \\
\hline River mile 45 & 6,004 & 4,204 & 5,794 & 5,916 & 4,137 & 2,569 & 3,947 & 4,376 \\
\hline River mile 47 & 5,036 & 5,770 & 4,958 & 5,999 & 3,250 & 3,163 & 3,243 & 6,491 \\
\hline River mile 50 & 1,948 & 2,814 & 1,859 & 1,313 & 675 & 2,035 & 566 & 0 \\
\hline River mile 51 & 2,938 & 4,670 & 3,030 & 3,093 & 1,364 & 3,125 & 1,407 & 2,806 \\
\hline River mile 55 & 4,849 & 5,733 & 4,638 & 4,912 & 3,912 & 4,369 & 3,763 & 4,426 \\
\hline mean & 3,720 & 4,129 & 3,637 & 3,820 & 2,370 & 2,697 & 2,315 & 3,174 \\
\hline standard deviation & 1,828 & 1,660 & 1,750 & 2,083 & 1,573 & 1,167 & 1,506 & 2,429 \\
\hline \multicolumn{9}{|l|}{$\begin{array}{l}\text { Upper Grand } \\
\text { Canyon }\end{array}$} \\
\hline River mile 62 & 784 & 750 & 789 & 740 & 281 & 402 & 253 & 323 \\
\hline River mile 65 & 5,328 & 6,790 & 4,895 & 5,753 & 1,440 & 4,127 & 1,173 & 3,081 \\
\hline River mile 68 & 2,434 & 2,113 & 1,960 & 2,699 & 2,889 & 2,585 & 2,897 & 3,015 \\
\hline River mile 81 & 609 & 663 & 597 & 630 & 440 & 644 & 399 & 782 \\
\hline River mile 87 & 386 & 342 & 408 & 331 & 384 & 326 & 380 & 309 \\
\hline mean & 1,908 & 2,132 & 1,730 & 2,031 & 1,087 & 1,617 & 1,020 & 1,502 \\
\hline standard deviation & 2,076 & 2,691 & 1,870 & 2,281 & 1,111 & 1,683 & 1,110 & 1,424 \\
\hline
\end{tabular}


Table 7. Area $\left(\mathrm{m}^{2}\right)$ and volume $\left(\mathrm{m}^{3}\right)$ of fine sediment at each study site, within the high-elevationeddy, mid-elevation-eddy, low-elevation-eddy, and main-channel zones. Data were collected in March, June, August, and September 2000.-Continued

\begin{tabular}{|c|c|c|c|c|c|c|c|c|}
\hline \multirow[t]{3}{*}{ Location } & \multicolumn{8}{|c|}{$\begin{array}{l}\text { Low-elevation fine sediment } \\
\text { (below the stage associated with discharge of } 227 \mathrm{~m}^{3} / \mathrm{s} \text { ) }\end{array}$} \\
\hline & \multicolumn{4}{|c|}{ Area, in square meters } & \multicolumn{4}{|c|}{ Volume, in cubic meters } \\
\hline & March & June & August & September & March & June & August & September \\
\hline \multicolumn{9}{|l|}{ Glen Canyon } \\
\hline River mile -6 & 8,553 & NA & NA & 8054 & 8,802 & NA & NA & 9,691 \\
\hline \multicolumn{9}{|l|}{$\begin{array}{l}\text { Upper Marble } \\
\text { Canyon }\end{array}$} \\
\hline River mile 3 & 20,654 & NA & NA & 20,008 & 34,650 & $\mathrm{NA}$ & NA & 33,888 \\
\hline River mile 8 & NA & NA & NA & NA & NA & NA & NA & NA \\
\hline River mile 16 & 13,575 & NA & NA & NA & 9,552 & NA & NA & NA \\
\hline River mile 22 & 8,886 & 7,417 & 10,277 & 7,272 & 5,262 & 4,085 & 5,543 & 5,357 \\
\hline River mile 30 & 12,978 & 12,398 & 12,253 & 9,922 & 6,842 & 7,094 & 3,183 & 7,977 \\
\hline River mile 32 & 13,431 & 14,861 & 13,673 & 14,195 & 7,328 & 6,390 & 6,955 & 5,308 \\
\hline River mile 35 & 12,503 & 26,624 & 20,665 & 7,726 & 18,134 & 9,234 & 40,508 & 464 \\
\hline mean & 13,671 & 15,325 & 14,217 & 11,824 & 13,628 & 6,701 & 14,047 & 10,599 \\
\hline standard deviation & 3,836 & 8,144 & 4,519 & 5,332 & 11,266 & 2,122 & 17,709 & 13,299 \\
\hline \multicolumn{9}{|l|}{$\begin{array}{l}\text { Lower Marble } \\
\text { Canyon }\end{array}$} \\
\hline River mile 43 & 7,487 & NA & NA & 7,007 & 37,812 & NA & NA & 29,981 \\
\hline River mile 45 & 43,393 & NA & NA & 30,076 & 20,876 & NA & NA & 17,703 \\
\hline River mile 47 & 46,014 & 48,669 & 47,574 & 38,624 & 24,496 & 25,642 & 29,099 & 25,035 \\
\hline River mile 50 & 3,801 & NA & NA & 3,642 & 4,550 & NA & NA & 8,581 \\
\hline River mile 51 & 59,644 & 48,956 & 63,241 & 48,920 & 36,043 & 38,595 & 37,679 & 34,630 \\
\hline River mile 55 & 42,771 & NA & NA & 34,183 & 47,264 & NA & NA & 47,675 \\
\hline mean & 33,852 & 48,812 & 55,407 & 27,075 & 28,507 & 32,119 & 33,389 & 27,268 \\
\hline standard deviation & 22,724 & 203 & 11,078 & 18,011 & 15,123 & 9,159 & 6,067 & 13,592 \\
\hline \multicolumn{9}{|l|}{$\begin{array}{l}\text { Upper Grand } \\
\text { Canyon }\end{array}$} \\
\hline River mile 62 & 13,115 & 13,965 & 11,659 & 14,023 & 6,303 & 7,769 & 4,232 & 4,310 \\
\hline River mile 65 & 23,088 & NA & NA & 20,980 & 14,463 & NA & NA & 17,013 \\
\hline River mile 68 & 17,482 & NA & NA & 11,655 & 12,245 & NA & NA & 8,476 \\
\hline River mile 81 & 297 & NA & NA & NA & 2,839 & NA & NA & NA \\
\hline River mile 87 & 252 & NA & NA & NA & 4,254 & NA & NA & NA \\
\hline mean & 10,847 & NA & NA & 15,553 & 8,021 & NA & NA & 9,933 \\
\hline standard deviation & 10,278 & NA & NA & 4,847 & 5,083 & NA & NA & 6,476 \\
\hline
\end{tabular}


Table 8. Percentage change in fine-sediment area and volume in each study site relative to the areas and volumes in March 2000, within the high-elevation-eddy, mid-elevation-eddy, lowelevation-eddy, and main-channel zones.

\begin{tabular}{|c|c|c|c|c|c|c|}
\hline \multirow[t]{3}{*}{ Location } & \multicolumn{6}{|c|}{$\begin{array}{c}\text { High-elevation fine sediment } \\
\text { (above stage associated with discharge of } 708 \mathrm{~m}^{3} / \mathrm{s} \text { ) }\end{array}$} \\
\hline & \multicolumn{3}{|c|}{ Area, in square meters } & \multicolumn{3}{|c|}{ Volume, in cubic meters } \\
\hline & June & August & September & June & August & September \\
\hline \multicolumn{7}{|l|}{ Glen Canyon } \\
\hline River mile -6 & 25.36 & -7.42 & 2.87 & 13.88 & -3.97 & 7.37 \\
\hline \multicolumn{7}{|l|}{$\begin{array}{l}\text { Upper Marble } \\
\text { Canyon }\end{array}$} \\
\hline River mile 3 & 0.76 & 0 & 1.52 & 0 & -4.49 & -2.25 \\
\hline River mile 8 & 2.29 & -4.2 & 1.65 & 1.65 & -5.85 & 1.1 \\
\hline River mile 16 & 1.96 & 3.92 & -2.94 & -19.05 & 0 & 2.38 \\
\hline River mile 22 & 0.9 & -0.9 & 52.4 & -3.1 & 2.52 & 4.84 \\
\hline River mile 30 & -1.77 & -2.55 & 4.13 & -3.73 & -5.8 & -3.04 \\
\hline River mile 32 & 0.81 & -2.15 & 0.67 & -3.64 & -6.67 & -1.7 \\
\hline River mile 35 & -1.96 & -0.13 & 1.57 & -2.89 & 0 & -0.9 \\
\hline mean & 0 & -1 & 8 & -4 & -3 & 0 \\
\hline standard deviation & 2 & 3 & 20 & 7 & 4 & 3 \\
\hline \multicolumn{7}{|l|}{$\begin{array}{l}\text { Lower Marble } \\
\text { Canyon }\end{array}$} \\
\hline River mile 43 & -1.1 & 0.63 & 0.55 & -2.66 & -0.34 & -0.1 \\
\hline River mile 45 & -0.2 & 2.82 & 2.32 & -4 & 0.99 & 0.23 \\
\hline River mile 47 & -6.19 & 0 & 6.19 & -6.89 & -0.09 & 1.61 \\
\hline River mile 50 & 2.53 & -1.44 & 4.89 & -1.27 & -1.85 & 1.17 \\
\hline River mile 51 & 5.22 & -0.75 & 4.09 & 0.06 & -0.36 & 0 \\
\hline River mile 55 & -0.2 & -1.63 & 3.4 & 0.05 & -0.48 & 0.71 \\
\hline mean & 0 & 0 & 4 & -2 & 0 & 1 \\
\hline standard deviation & 4 & 2 & 2 & 3 & 1 & 1 \\
\hline \multicolumn{7}{|l|}{$\begin{array}{l}\text { Upper Grand } \\
\text { Canyon }\end{array}$} \\
\hline River mile 62 & 14.09 & -4.12 & 14.43 & 3.04 & -2.17 & 3.04 \\
\hline River mile 65 & -0.44 & -4.66 & 9.32 & -6.75 & 0.75 & 1.75 \\
\hline River mile 68 & -2.55 & 13.32 & 1.16 & -2.96 & -7 & 0.91 \\
\hline River mile 81 & 0.87 & -0.87 & 6.33 & -5.81 & -2.22 & 2.08 \\
\hline River mile 87 & 5.88 & -2.65 & 1.18 & 4.92 & -3.08 & -2.15 \\
\hline mean & 4 & 0 & 6 & -2 & -3 & 1 \\
\hline standard deviation & 7 & 7 & 6 & 5 & 3 & 2 \\
\hline
\end{tabular}


Table 8. Percentage change in fine-sediment area and volume in each study site relative to the areas and volumes in March 2000, within the high-elevation-eddy, mid-elevation-eddy, lowelevation-eddy, and main-channel zones.-Continued

\begin{tabular}{|c|c|c|c|c|c|c|}
\hline \multirow[t]{3}{*}{ Location } & \multicolumn{6}{|c|}{$\begin{array}{c}\text { Mid-elevation fine sediment } \\
\text { (between stages associated with discharges of } 227 \text { and } 708 \mathrm{~m}^{3} / \mathrm{s} \text { ) }\end{array}$} \\
\hline & \multicolumn{3}{|c|}{ Area, in square meters } & \multicolumn{3}{|c|}{ Volume, in cubic meters } \\
\hline & June & August & September & June & August & September \\
\hline \multicolumn{7}{|l|}{ Glen Canyon } \\
\hline River mile -6 & 16.79 & 9.39 & -9.94 & 133.5 & 6.8 & -23.64 \\
\hline \multicolumn{7}{|l|}{$\begin{array}{l}\text { Upper Marble } \\
\text { Canyon }\end{array}$} \\
\hline River mile 3 & -15.44 & -49.5 & 2.43 & -75.06 & -2.53 & 0.9 \\
\hline River mile 8 & 5.18 & -21.79 & 5.41 & 3.42 & -30.14 & 3.2 \\
\hline River mile 16 & -6.05 & -5.67 & 9.19 & -1.01 & -30.65 & 19.1 \\
\hline River mile 22 & 15.51 & -3.07 & 4.05 & 42.96 & -1.6 & 39.91 \\
\hline River mile 30 & -1.74 & -5.49 & 16.21 & 84.61 & -7.66 & 40.03 \\
\hline River mile 32 & 15.82 & -7.35 & 57.17 & 32.47 & -31.17 & 333.12 \\
\hline River mile 35 & 73.14 & -42.06 & 45.35 & 243.09 & -112.71 & 305.52 \\
\hline mean & 12 & -19 & 20 & 47 & -31 & 106 \\
\hline standard deviation & 29 & 19 & 22 & 99 & 39 & 147 \\
\hline \multicolumn{7}{|l|}{$\begin{array}{l}\text { Lower Marble } \\
\text { Canyon }\end{array}$} \\
\hline River mile 43 & 2.59 & -0.06 & 9.39 & 4.3 & 9.06 & 23.22 \\
\hline River mile 45 & -29.98 & -3.5 & -1.47 & -37.9 & -4.59 & 5.78 \\
\hline River mile 47 & 14.58 & -1.55 & 19.12 & -2.68 & -0.22 & 99.72 \\
\hline River mile 50 & 44.46 & -4.57 & -32.6 & 201.48 & -16.15 & -121.04 \\
\hline River mile 51 & 58.95 & 3.13 & 5.28 & 129.11 & 3.15 & 105.72 \\
\hline River mile 55 & 18.23 & -4.35 & 1.3 & 11.68 & -3.81 & 13.14 \\
\hline mean & 18 & -2 & 0 & 51 & -2 & 21 \\
\hline standard deviation & 31 & 3 & 18 & 93 & 9 & 82 \\
\hline \multicolumn{7}{|l|}{$\begin{array}{l}\text { Upper Grand } \\
\text { Canyon }\end{array}$} \\
\hline River mile 62 & -4.34 & 0.64 & -5.61 & 43.06 & -9.96 & 14.95 \\
\hline River mile 65 & 27.44 & -8.13 & 7.98 & 186.6 & -18.54 & 113.96 \\
\hline River mile 68 & -13.19 & -19.47 & 10.89 & -10.52 & 0.28 & 4.36 \\
\hline River mile 81 & 8.87 & -1.97 & 3.45 & 46.36 & -9.32 & 77.73 \\
\hline River mile 87 & -11.4 & 5.7 & -14.25 & -15.1 & -1.04 & -19.53 \\
\hline mean & 1 & -5 & 0 & 50 & -8 & 38 \\
\hline standard deviation & 17 & 10 & 10 & 82 & 8 & 55 \\
\hline
\end{tabular}


Table 8. Percentage change in fine-sediment area and volume in each study site relative to the areas and volumes in March 2000, within the high-elevation-eddy, mid-elevation-eddy, lowelevation-eddy, and main-channel zones.-Continued

\begin{tabular}{|c|c|c|c|c|c|c|}
\hline \multirow[t]{3}{*}{ Location } & \multicolumn{6}{|c|}{$\begin{array}{l}\text { Low-elevation fine sediment } \\
\text { (below the stage associated with discharge of } 227 \mathrm{~m}^{3} / \mathrm{s} \text { ) }\end{array}$} \\
\hline & \multicolumn{3}{|c|}{ Area, in square meters } & \multicolumn{3}{|c|}{ Volume, in cubic meters } \\
\hline & June & August & September & June & August & September \\
\hline \multicolumn{7}{|l|}{ Glen Canyon } \\
\hline River mile -6 & NA & NA & -5.83 & NA & NA & 10.1 \\
\hline \multicolumn{7}{|l|}{$\begin{array}{l}\text { Upper Marble } \\
\text { Canyon }\end{array}$} \\
\hline \begin{tabular}{|l} 
River mile 3 \\
River mile 8 \\
River mile 16 \\
River mile 22 \\
River mile 30 \\
River mile 32 \\
River mile 35 \\
\end{tabular} & $\begin{array}{c}\text { NA } \\
\text { NA } \\
\text { NA } \\
-16.53 \\
-4.47 \\
10.65 \\
112.94 \\
\end{array}$ & $\begin{array}{c}\text { NA } \\
\text { NA } \\
\text { NA } \\
15.65 \\
-5.59 \\
1.8 \\
65.28 \\
\end{array}$ & $\begin{array}{c}-3.13 \\
\text { NA } \\
\text { NA } \\
-18.16 \\
-23.55 \\
5.69 \\
-38.21 \\
\end{array}$ & $\begin{array}{c}\text { NA } \\
\text { NA } \\
\text { NA } \\
-22.37 \\
3.68 \\
-12.8 \\
-49.08 \\
\end{array}$ & $\begin{array}{c}\text { NA } \\
\text { NA } \\
\text { NA } \\
5.34 \\
-53.48 \\
-5.09 \\
123.38 \\
\end{array}$ & $\begin{array}{c}1.81 \\
16.59 \\
-27.57 \\
-97.44 \\
\end{array}$ \\
\hline \begin{tabular}{|l} 
mean \\
standard deviation
\end{tabular} & $\begin{array}{l}26 \\
59\end{array}$ & $\begin{array}{l}19 \\
32 \\
\end{array}$ & $\begin{array}{c}-15 \\
17\end{array}$ & $\begin{array}{l}-20 \\
22 \\
\end{array}$ & $\begin{array}{l}18 \\
75\end{array}$ & $\begin{array}{l}-22 \\
45 \\
\end{array}$ \\
\hline \multicolumn{7}{|l|}{$\begin{array}{l}\text { Lower Marble } \\
\text { Canyon }\end{array}$} \\
\hline \begin{tabular}{|l|} 
River mile 43 \\
River mile 45 \\
River mile 47 \\
River mile 50 \\
River mile 51 \\
River mile 55 \\
\end{tabular} & $\begin{array}{c}\text { NA } \\
\text { NA } \\
5.77 \\
\text { NA } \\
-17.92 \\
\text { NA } \\
\end{array}$ & $\begin{array}{l}\text { NA } \\
\text { NA } \\
3.39 \\
\text { NA } \\
6.03 \\
\text { NA } \\
\end{array}$ & $\begin{array}{c}-6.41 \\
-30.69 \\
-16.06 \\
-4.18 \\
-17.98 \\
-20.08 \\
\end{array}$ & $\begin{array}{l}\text { NA } \\
\text { NA } \\
4.68 \\
\text { NA } \\
7.08 \\
\text { NA } \\
\end{array}$ & $\begin{array}{c}\text { NA } \\
\text { NA } \\
18.79 \\
\text { NA } \\
4.54 \\
\text { NA } \\
\end{array}$ & $\begin{array}{c}-20.71 \\
-15.2 \\
2.2 \\
88.59 \\
-3.92 \\
0.87 \\
\end{array}$ \\
\hline $\begin{array}{l}\text { mean } \\
\text { standard deviation }\end{array}$ & $\begin{array}{l}-6 \\
17 \\
\end{array}$ & $\begin{array}{l}5 \\
2 \\
\end{array}$ & $\begin{array}{c}-16 \\
10 \\
\end{array}$ & $\begin{array}{l}6 \\
2 \\
\end{array}$ & $\begin{array}{l}12 \\
10\end{array}$ & $\begin{array}{c}9 \\
40 \\
\end{array}$ \\
\hline \multicolumn{7}{|l|}{$\begin{array}{l}\text { Upper Grand } \\
\text { Canyon }\end{array}$} \\
\hline $\begin{array}{l}\text { River mile } 62 \\
\text { River mile } 65 \\
\text { River mile } 68 \\
\text { River mile } 81 \\
\text { River mile } 87\end{array}$ & $\begin{array}{l}6.48 \\
\text { NA } \\
\text { NA } \\
\text { NA } \\
\text { NA }\end{array}$ & $\begin{array}{l}-11.1 \\
\text { NA } \\
\text { NA } \\
\text { NA } \\
\text { NA }\end{array}$ & $\begin{array}{c}6.92 \\
-9.13 \\
-33.33 \\
\text { NA } \\
\text { NA }\end{array}$ & $\begin{array}{c}23.26 \\
\text { NA } \\
\text { NA } \\
\text { NA } \\
\text { NA }\end{array}$ & $\begin{array}{c}-32.86 \\
\text { NA } \\
\text { NA } \\
\text { NA } \\
\text { NA }\end{array}$ & $\begin{array}{c}-31.62 \\
17.63 \\
-30.78 \\
\text { NA } \\
\text { NA }\end{array}$ \\
\hline \begin{tabular}{|l} 
mean \\
standard deviation
\end{tabular} & $\begin{array}{c}6 \\
\text { NA } \\
\end{array}$ & $\begin{array}{l}-11 \\
\text { NA }\end{array}$ & $\begin{array}{c}-12 \\
20 \\
\end{array}$ & $\begin{array}{r}23 \\
\text { NA } \\
\end{array}$ & $\begin{array}{l}-33 \\
\text { NA }\end{array}$ & $\begin{array}{c}-15 \\
28 \\
\end{array}$ \\
\hline
\end{tabular}


Table 9. Volumes and rates of fine sediment either eroded or deposited in the eddy part of the faneddy complex at river mile 30 during the September 2000 habitat maintenance flows (HMF). Amount of scour, fill, and net change is in cubic meters; rates are in cubic meters per hour.

\begin{tabular}{|c|c|c|c|c|c|c|c|}
\hline \multicolumn{2}{|c|}{ Survey Interval } & $\begin{array}{c}\text { Scour } \\
\left(\mathrm{m}^{3}\right)\end{array}$ & $\begin{array}{l}\text { Fill } \\
\left(\mathrm{m}^{3}\right)\end{array}$ & $\begin{array}{c}\text { Net change } \\
\left(\mathrm{m}^{3}\right)\end{array}$ & $\begin{array}{l}\text { Scour rate } \\
\text { (m³/hour) }\end{array}$ & $\begin{array}{l}\text { Fill rate } \\
\text { ( } \mathrm{m}^{3} / \text { hour) }\end{array}$ & $\begin{array}{c}\text { Rate of net } \\
\text { change } \\
\text { (m²/hour) }\end{array}$ \\
\hline Pre-HMF & Day 1 (11am) & 7,629 & 796 & $-6,833$ & - & - & - \\
\hline Day 1 (11am) & Day $1(2 \mathrm{pm})$ & 652 & 2,516 & 1,864 & 217 & 839 & 621 \\
\hline Day 1 (2 pm) & Day 1 (5 pm) & 575 & 776 & 201 & 192 & 259 & 67 \\
\hline Day 1 (5 pm) & Day 2 (9 am) & 4,344 & 2,329 & $-2,015$ & 272 & 146 & -126 \\
\hline Day 2 (9 am) & Day $2(3 \mathrm{pm})$ & 985 & 1,389 & 404 & 164 & 232 & 67 \\
\hline Day $2(3 \mathrm{pm})$ & Day 3 (9 am) & 1,317 & 1,869 & 552 & 73 & 104 & 31 \\
\hline Day 3 (9 am) & Day 3 (3 pm) & 443 & 1,075 & 632 & 74 & 179 & 105 \\
\hline Day 3 (3 pm) & Day 4 (9 am) & 596 & 1,356 & 760 & 33 & 75 & 42 \\
\hline Day 4 (9 am) & Day 4 (3 pm) & 421 & 974 & 553 & 70 & 162 & 92 \\
\hline Day 4 (3 pm) & Post-HMF & 452 & 1,744 & 1,292 & - & - & - \\
\hline Pre-HMF & Post-HMF & 5,282 & 2,766 & $-2,516$ & & & \\
\hline
\end{tabular}


Table 10. Average response of the bed and eddy sandbars to various flow regimes of the low summer steady flows (LSSF) in different parts of the study area. "NA" indicates no data available, "?" indicates indeterminate response, "-“ indicates loss or decrease in area or volume, and " + " indicates increase or gain in area or volume.

\begin{tabular}{|c|c|c|c|c|c|c|c|c|c|c|c|}
\hline \multirow[b]{2}{*}{ Period } & \multicolumn{2}{|c|}{ Mass balance } & \multirow{2}{*}{$\begin{array}{c}\begin{array}{c}\text { Area of } \\
\text { sand on } \\
\text { bed }\end{array} \\
\text { Marble } \\
\text { Canyon }\end{array}$} & \multirow[t]{2}{*}{$\begin{array}{c}\text { Fine- } \\
\text { sediment } \\
\text { grain size } \\
\text { on bed } \\
\end{array}$} & \multirow{2}{*}{$\begin{array}{c}\beta \\
\\
\text { Marble } \\
\text { and } \\
\text { upper } \\
\text { Grand } \\
\text { Canyons } \\
\end{array}$} & \multicolumn{2}{|c|}{$\begin{array}{l}\text { Eddy bars at mid- } \\
\text { elevation } \\
\text { (determined from } \\
\text { ground surveys) }\end{array}$} & \multicolumn{4}{|c|}{$\begin{array}{l}\text { Eddy bars at mid-elevation (determined from } \\
\text { aerial photographs) }\end{array}$} \\
\hline & $\begin{array}{l}\text { Marble } \\
\text { Canyon }\end{array}$ & $\begin{array}{l}\text { upper } \\
\text { Grand } \\
\text { Canyon }\end{array}$ & & & & $\begin{array}{l}\text { Upper } \\
\text { Marble } \\
\text { Canyon }\end{array}$ & $\begin{array}{l}\text { Lower } \\
\text { Marble } \\
\text { Canyon }\end{array}$ & $\begin{array}{l}\text { Lees } \\
\text { Ferry } \\
\text { reach }\end{array}$ & $\begin{array}{l}\text { Redwall } \\
\text { Gorge } \\
\text { reach }\end{array}$ & $\begin{array}{c}\text { Point } \\
\text { Hansborough } \\
\text { reach }\end{array}$ & $\begin{array}{c}\text { Tapeats } \\
\text { Gorge } \\
\text { reach }\end{array}$ \\
\hline 1 & - & $?$ & $\mathrm{NA}$ & NA & fines & $\mathrm{NA}$ & NA & $\mathrm{NA}$ & NA & NA & NA \\
\hline 2 & - & $?$ & NA & NA & coarsens & + & + & $\mathrm{NA}$ & NA & NA & NA \\
\hline 3 & - & $?$ & NA & NA & coarsens & NA & NA & NA & NA & NA & NA \\
\hline 4 & + & + & + & coarsens & coarsens & - & - & NA & NA & NA & NA \\
\hline 5 & - & $?$ & NA & NA & coarsens & + & + & - & + & - & + \\
\hline
\end{tabular}

\begin{tabular}{|l|l|l|l|}
\hline & \multicolumn{2}{|c|}{$\begin{array}{c}\text { Eddy bars at low } \\
\text { elevation }\end{array}$} & $\begin{array}{c}\text { Backwater } \\
\text { area }\end{array}$ \\
\hline Period & $\begin{array}{c}\text { Upper } \\
\text { Marble } \\
\text { Canyon }\end{array}$ & $\begin{array}{c}\text { Lower } \\
\text { Marble } \\
\text { Canyon }\end{array}$ & $\begin{array}{c}\text { Marble } \\
\text { Canyon }\end{array}$ \\
\hline Period & & & \\
\hline 1 & - & NA & NA \\
\hline 2 & NA & NA & NA \\
\hline 3 & + & + & NA \\
\hline 4 & - & - & + \\
\hline
\end{tabular}

